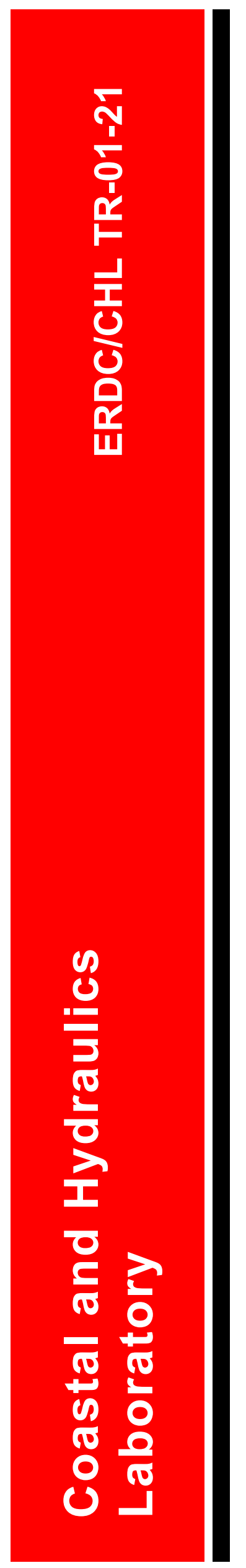

Monitoring Completed Navigation Projects Program

Morro Bay Harbor, California, Wave and Current Data Summary Report

Andrew W. Garcia

September 2001

Approved for public release; distribution is unlimited. 
The contents of this report are not to be used for advertising, publication, or promotional purposes. Citation of trade names does not constitute an official endorsement or approval of the use of such commercial products.

The findings of this report are not to be construed as an official Department of the Army position, unless so designated by other authorized documents. 


\section{Morro Bay Harbor, California, Wave and Current Data Summary Report}

by Andrew W. Garcia

Coastal and Hydraulics Laboratory

U.S. Army Engineer Research and Development Center 3909 Halls Ferry Road

Vicksburg, MS 39180-6199

Final report

Approved for public release; distribution is unlimited 


\section{Contents}

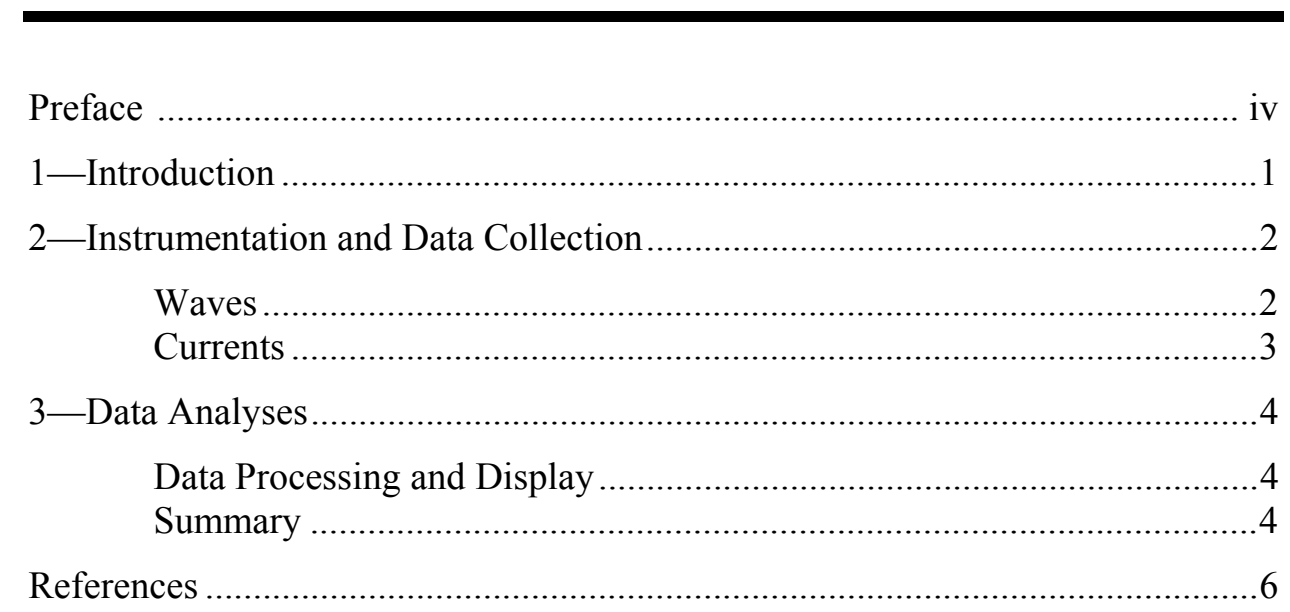

Figures 1-65

SF 298 


\section{Preface}

The work described in this report was authorized by the Operations and Maintenance Division, Headquarters, U.S. Army Corps of Engineers (HQUSACE) and completed as part of the Monitoring Completed Navigation Projects (MCNP) Program. It is a product of the U.S. Engineer Research and Development Center (ERDC), Coastal and Hydraulics Laboratory (CHL), under the direction of Mr. Thomas W. Richardson, Acting Director, CHL; and the direct guidance of Mr. William L. Preslan, Chief of the Prototype Measurement and Analysis Branch (PMAB). Dr. Andrew Garcia of PMAB was manager for the Morro Bay field studies reported herein.

Messrs. Larry G. Caviness and Ralph E. Ankeny, both of PMAB, conducted wave gauge deployments and maintenance. Wave gauge data were processed and analyzed by Mr. James P. McKinney. Ms. Margaret A. Sabol generated wave summary plots and data tables.

Mr. Michael W. Tubman, also of PMAB, conducted the Acoustic Doppler Current Profiler (ADCP) deployment, retrieval, and data analysis. Evans Hamilton, Inc., a PMAB contractor, deployed a surface following Waverider buoy, and collected and analyzed the data.

This report was written by Dr. Andrew W. Garcia, and prepared by Ms. Terri L. Prickett for publication.

At the time of publication of this report, Dr. James R. Houston was Director of ERDC, and COL John W. Morris III, EN, was Commander and Executive Director.

The contents of this report are not to be used for advertising, publication, or promotional purposes. Citation of trade names does not constitute an official endorsement or approval of the use of such commercial products. 


\section{Introduction}

This document summarizes the U.S. Army Engineer Research and Development Center (ERDC), Coastal and Hydraulics Laboratory (CHL), Prototype Measurement and Analysis Branch (PMAB) wave and current data collection activities at Morro Bay Harbor, CA. The objective of this data collection was to provide wave and current information to evaluate recent modifications to the Morro Bay Harbor entrance.

Morro Bay Harbor, CA, is the only small-craft, commercial harbor between Monterey and Santa Barbara, CA. The harbor entrance is protected from the open ocean by two permeable rubble-mound breakwaters, an inner harbor groin, and a stone revetment. A plan view of the harbor entrance and navigation channel is shown in Figure 1. The Morro Bay Harbor has been considered dangerous because of large-breaking waves at the entrance that cause treacherous and hazardous passage. Since 1962, 19 boating accidents have occurred in the harbor entrance, resulting in 20 deaths, 67 injured individuals, and more than $\$ 600,000$ in vessel damages and losses (Bottin 1993). In 1995, the U.S. Army Corps of Engineers modified the harbor entrance channel to reduce the hazardous wave conditions.

Morro Bay Harbor was selected for inclusion in the Monitoring Completed Navigation Projects (MCNP) program in 1997. The Coastal Engineering Research Board (CERB), which oversees the conduct and research of Corps of Engineers coastal engineering projects, met in January 1997 to review various Corps projects in California, including Morro Bay Harbor. During the meeting, the CERB concurred with the monitoring program to evaluate the performance of completed modifications to the Morro Bay Harbor entrance. The recommended monitoring program included wave and current measurements inside the harbor entrance, wave measurements outside the harbor entrance, periodic bathymetric surveys, and ground and photogrammetric surveys of the south breakwater. Planning for the Morro Bay Harbor monitoring program took place in 1997 and monitoring was initiated in 1998. Wave and tide gauges were initially deployed in September 1998 and data collection continued for approximately 2 years.

Currents were measured during a 3-week period in the spring of 1999. 


\section{Instrumentation and Data Collection}

From September 1998 to August 2000, a surface-following buoy and a bottom-mounted directional slope-array collected wave measurements outside of the harbor entrance. In addition, a combined water-level/wave gauge was deployed between the inner and outer harbors. Tidal currents between the inner and outer harbors were measured for a 3-week period in 1999. Figure 1 shows the approximate locations of the instruments.

\section{Waves}

Waves near the harbor entrance were measured with a surface-following Datawell Waverider buoy anchored seaward of the south breakwater. The Waverider buoy transmitted data via radio-telecommunication, in real-time, to a receiving system located in a nearby U.S. Coast Guard facility. A surfacefollowing buoy was selected for measurements near the harbor entrance because a bottom-mounted pressure array was considered too vulnerable to vessel traffic in the narrow confines of the entrance channel. Moreover, sufficient bottom sediment movement at this location could have buried or undermined a bottommounted gauge. Both effects posed significant risk to survival of a bottommounted gauge.

Directional wave data were desired seaward of the north breakwater to help define the wave conditions incident to the breakwater and harbor entrance. A bottom-mounted, internally-recording surface slope array was selected. Such an arrangement was considered low-risk in terms of vulnerability to extreme wave conditions and offshore vessel traffic. However, because the instrument was selfcontained and recorded internally, there was no way to know if the gauge functioned properly once it was deployed. The slope array gauge system (designated CA002) was deployed on the seafloor approximately $305 \mathrm{~m}(1,000$ $\mathrm{ft}$ ) due west of the north breakwater (lat. $35.360 \mathrm{~N}$ and long. 120.876 W) in approximately $14.3-\mathrm{m}$ (47-ft) water depth.

A second internally recording bottom-mounted gauge system (designated CA001) was deployed in the outer harbor to collect nondirectional wave measurements and tide information. From September 1998 to April 2000, the system was deployed approximately $183 \mathrm{~m}(600 \mathrm{ft})$ due east of the north 
breakwater on the western edge of the navigation channel in about $6.1-\mathrm{m}(20-\mathrm{ft})$ water depth (see Site 1 in Figure 1). The gauge system was moved in April 2000, and redeployed approximately $366 \mathrm{~m}(1,200 \mathrm{ft})$ due east of the north breakwater (lat. $35.367 \mathrm{~N}$ and long. $120.866 \mathrm{~W}$ ) on the eastern edge of the navigation channel in about 7.9-m (26-ft) water depth (Site 2 in Figure 1). Both wave gauges (CA001 and CA002) collected measurements in sample bursts of 2,048 sec (35 min) every $120 \mathrm{~min}$. Tide level data from CA001 were sampled every $3.75 \mathrm{~min}$.

Following the September 1998 deployment, both bottom-mounted systems were retrieved four times during the 2-year monitoring period to check instrument function and download data. Once the data were downloaded from the gauge, the batteries were replaced and the instruments were redeployed to continue collecting data. The retrievals and redeployments took place in March and June 1999, and in January and April 2000. Data collection ended in August 2000 and both gauge systems were retrieved.

The slope-array instruments deployed for the Morro Bay study were specified by the vendor as having sufficient memory and battery capacity to operate for 12 months in the data acquisition format used. The Morro Bay Harbor project was the first time that the CHL-owned instruments were deployed in the long duration mode. Despite thorough inspection to ensure that batteries were fully charged and there were no apparent instrument abnormalities, the experience at Morro Bay showed battery life to be consistently between 4 and 6 months. Queries to the gauge manufacturer as to similar problems experienced by other users revealed there were only two other users of these type instruments at the time. Neither of these users had operated the gauges in multimonth duration deployments, and did not experience battery failure.

\section{Currents}

A 1,200 KHz Broad Band Acoustic Doppler Current Profiler (BBADCP) was deployed from 17 May to 9 June 1999 in the center of the navigation channel between the inner and outer harbors (lat. 35.367 and long.120.866) to internally record tidal current direction and speed (see Figure 1). The operational time period was chosen to encompass spring and neap tide conditions. The BBADCP was deployed in a water depth of approximately $6.7 \mathrm{~m}(22 \mathrm{ft})$, with $5.8 \mathrm{~m}(19 \mathrm{ft})$ over the instrument. The BBADCP recorded data an average of $30 \mathrm{sec}$ every 6 min. 


\section{Data Analyses}

\section{Data Processing and Display}

The Waverider data were processed and analyzed by contract field personnel using vendor-supplied software. The data were summarized in monthly plots of maximum and significant wave heights (Figures 2 through 12) and average wave periods and periods of maximum energy (Figures 13 through 23). Maximum wave heights were determined based on statistical relations given in LonguetHiggins (1952).

Data acquired by all the internal recording instruments (the directional gauge seaward of the north breakwater, the gauge inside the harbor, and the short-term deployment ADCP) were processed using the Prototype Measurement Analysis System (PMAS) software package (Sabol 1998).

Monthly wave data summary plots consisting of wave height, period, and direction from the bottom-mounted wave gauges were generated using the PMAS software. Data plots from the wave gauge deployed inside the harbor (CA001) are given in Figures 24 through 45 and data plots from the gauge offshore of the harbor (CA002) are given in Figures 46 through 61. The monthly plots and tabulated data from both CA001 and CA002 wave gauges are also available for public access on the Internet at: http://sandbar.wes.army.mil. Near-bottom, near-middepth, and near-surface current speeds and directions from the BBADCP deployment are given in Figures 62 and 63, respectively. Figures 64 and 65 are time series of ebb and flood near-surface currents during the current monitoring period.

\section{Summary}

Based upon the observations made during the field investigation, the following general comments can be made:

a. For significant wave heights exceeding $1.3 \mathrm{~m}$, dominant wave directions outside the breakwaters were confined to a narrow band of approximately $275 \pm 15 \mathrm{deg}$. 
b. Dominant wave periods exceeding $20 \mathrm{sec}$ occurred occasionally.

This report presents wave and current data obtained during the monitoring effort. A detailed analysis of hydrodynamic conditions versus harbor performance will subsequently be performed and published in a comprehensive monitoring report. 


\section{References}

Bottin, R. R. (1993). "Design for entrance channel navigation improvements, Morro Bay Harbor, Morro Bay, California," Technical Report CERC-93-2, Coastal Engineering Research Center, U.S. Army Engineer Waterways Experiment Station, Vicksburg, MS.

Longuet-Higgins, M. S. (1952). "On the statistical distribution of the heights of sea waves," Journal of Marine Research 11, 245-266.

Sabol, M. A. (1998). "Near real-time coastal monitoring," Coastal Engineering Technical Note (CETN) VI-30, Coastal and Hydraulics Laboratory, U.S. Army Engineer Research and Development Center, Vicksburg, MS. 


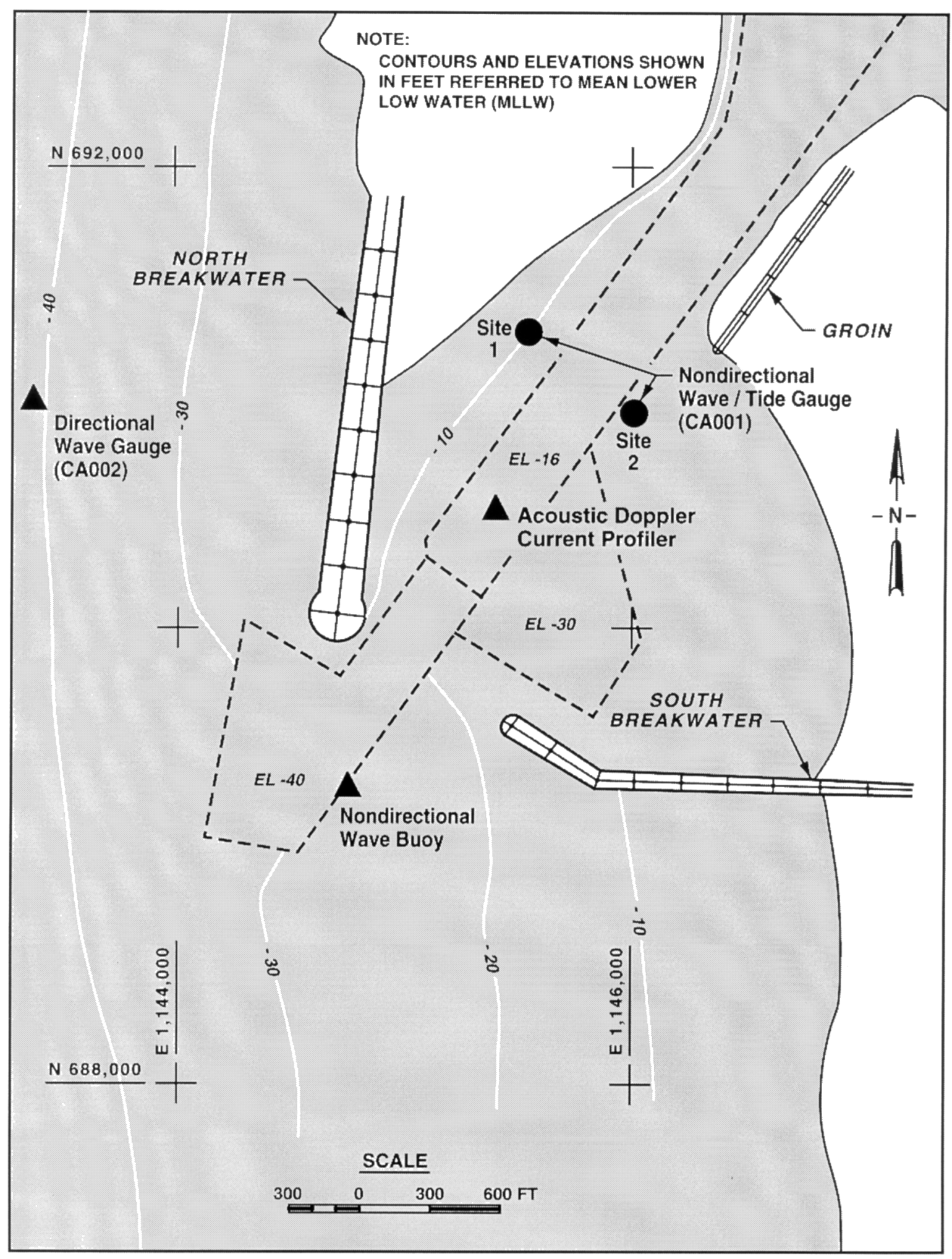

Figure 1. Plan view of Morro Bay Harbor (to convert feet to meters, multiply by 0.3048 ) 


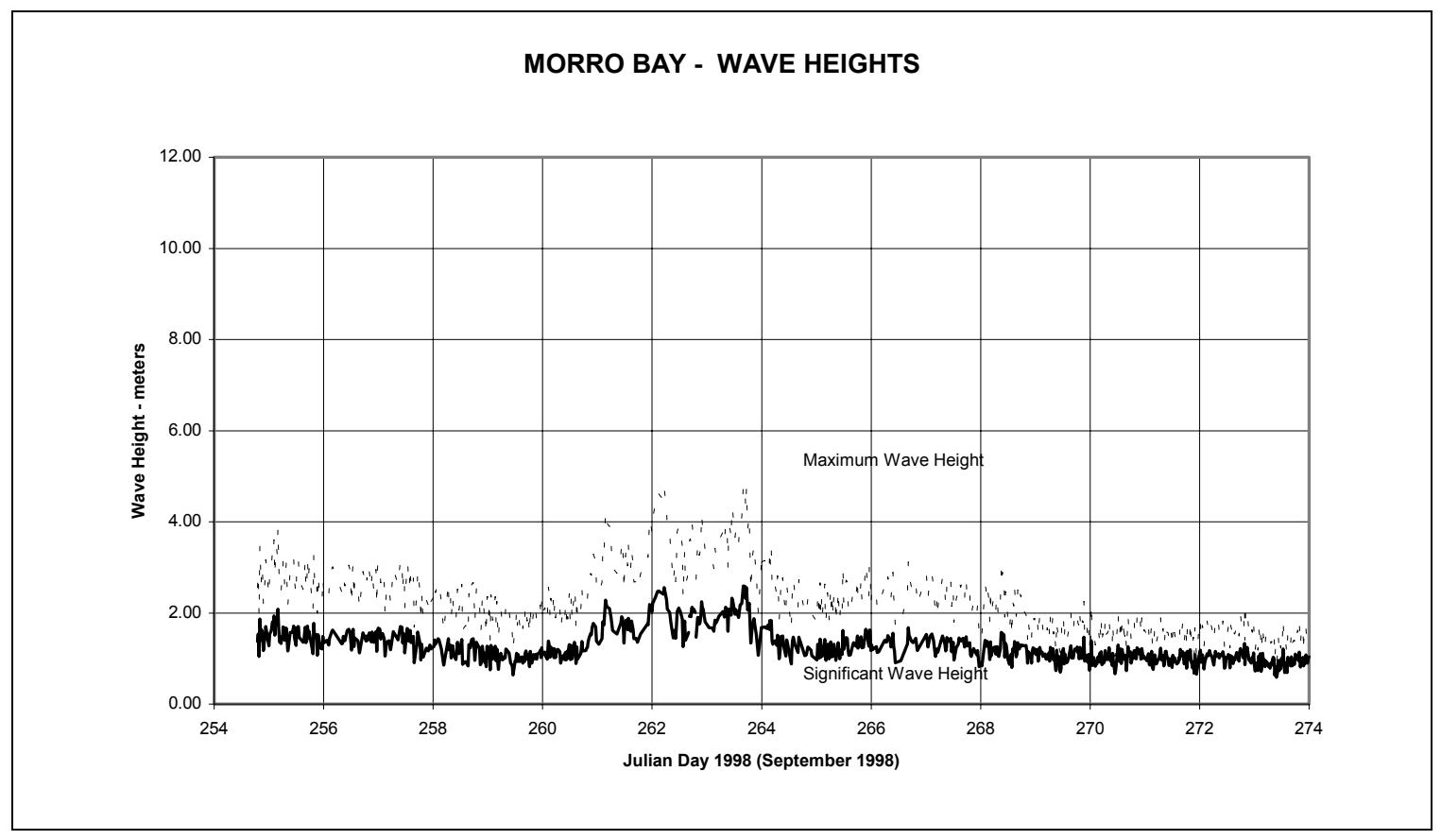

Figure 2. September 1998 maximum and significant wave heights

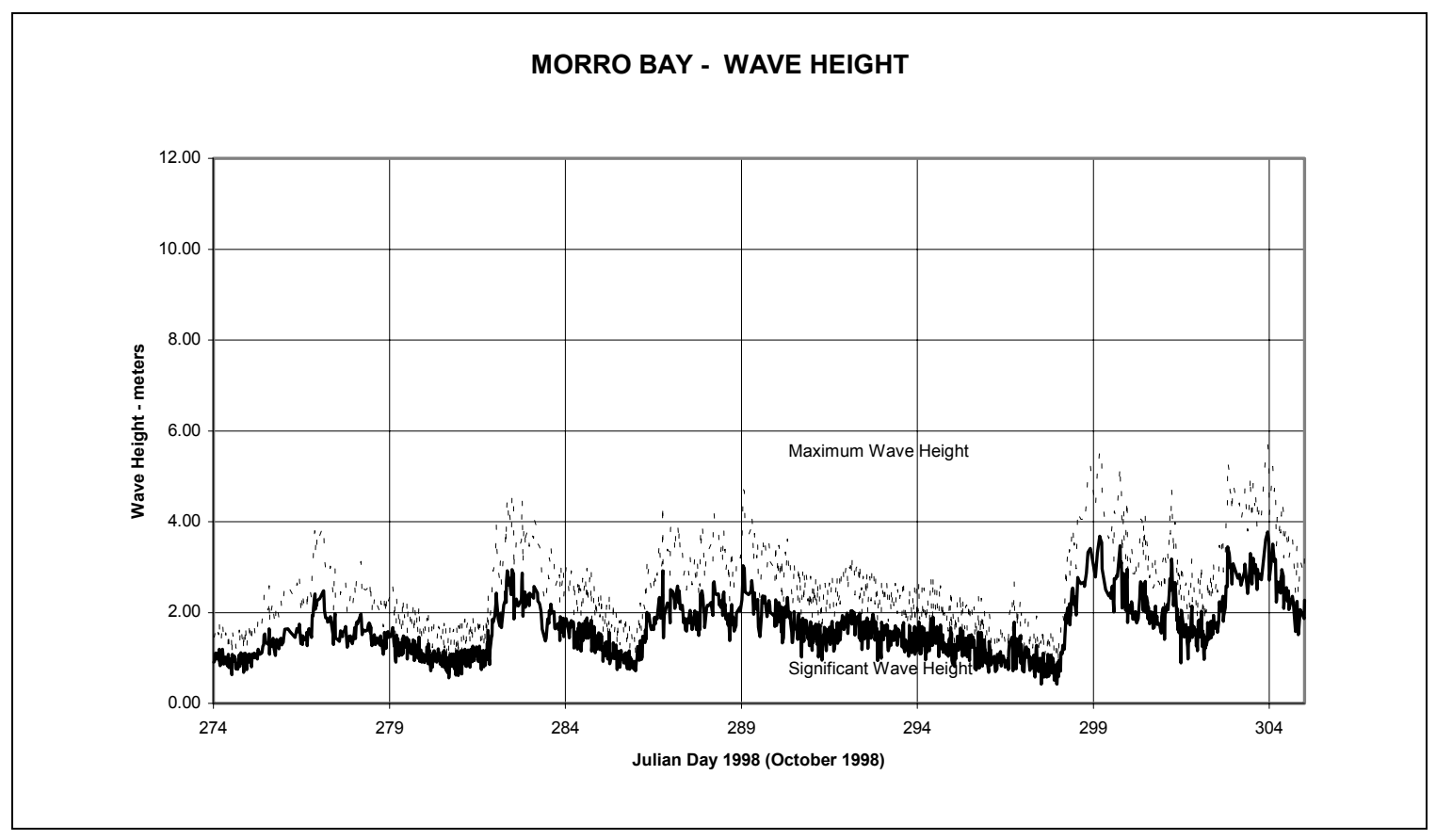

Figure 3. October 1998 maximum and significant wave heights 


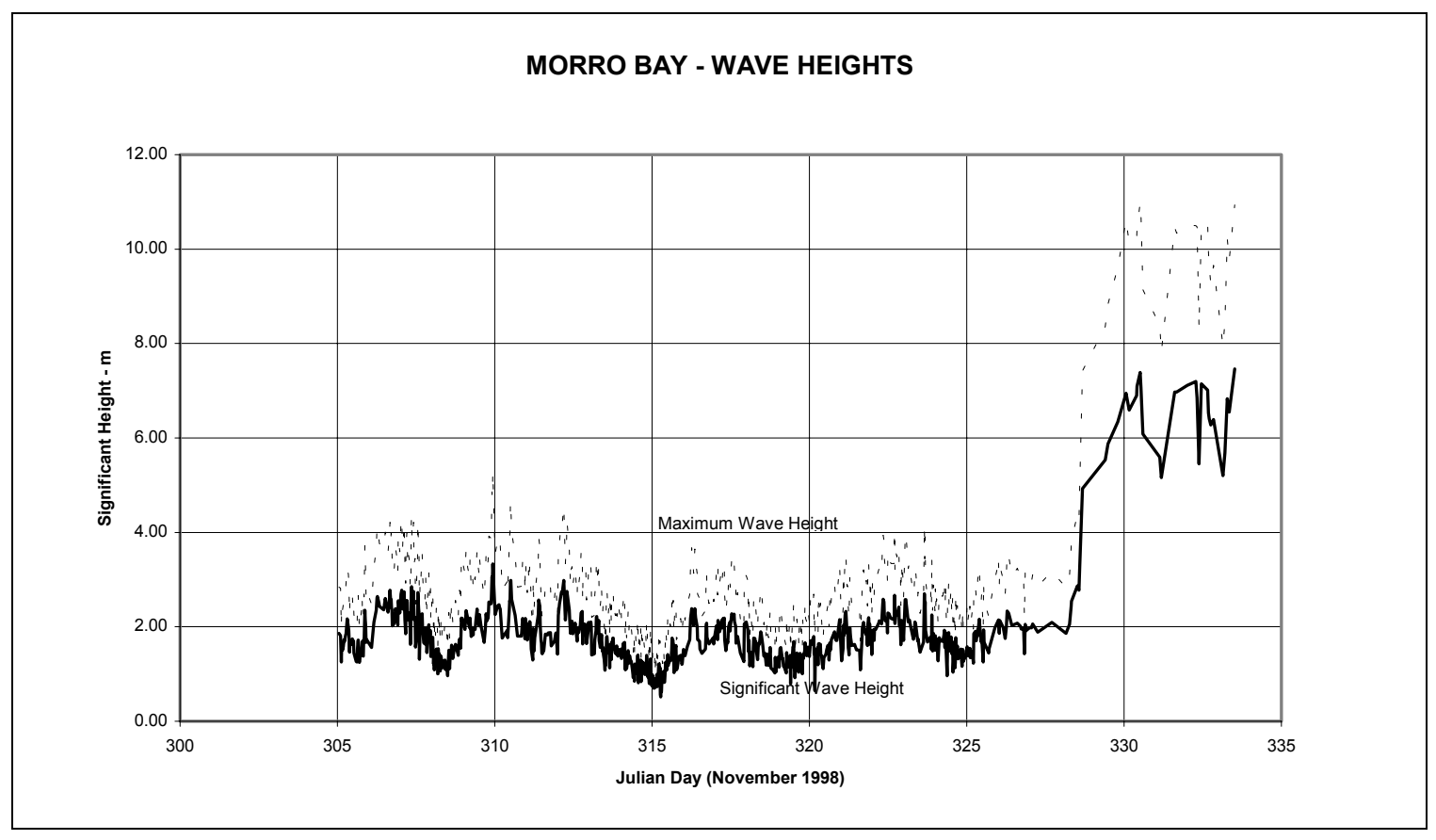

Figure 4. November 1998 maximum and significant wave heights

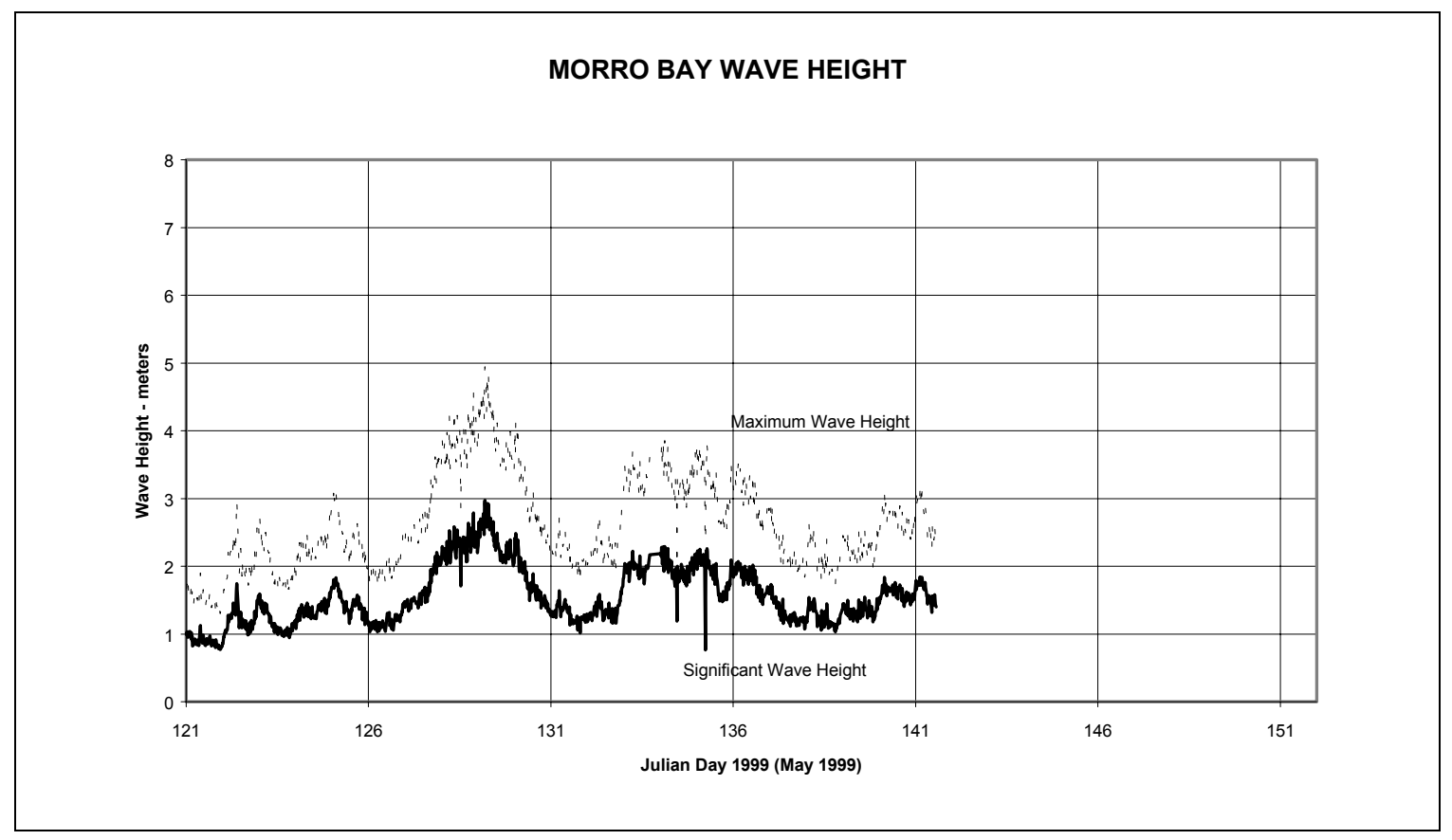

Figure 5. May 1999 maximum and significant wave heights 


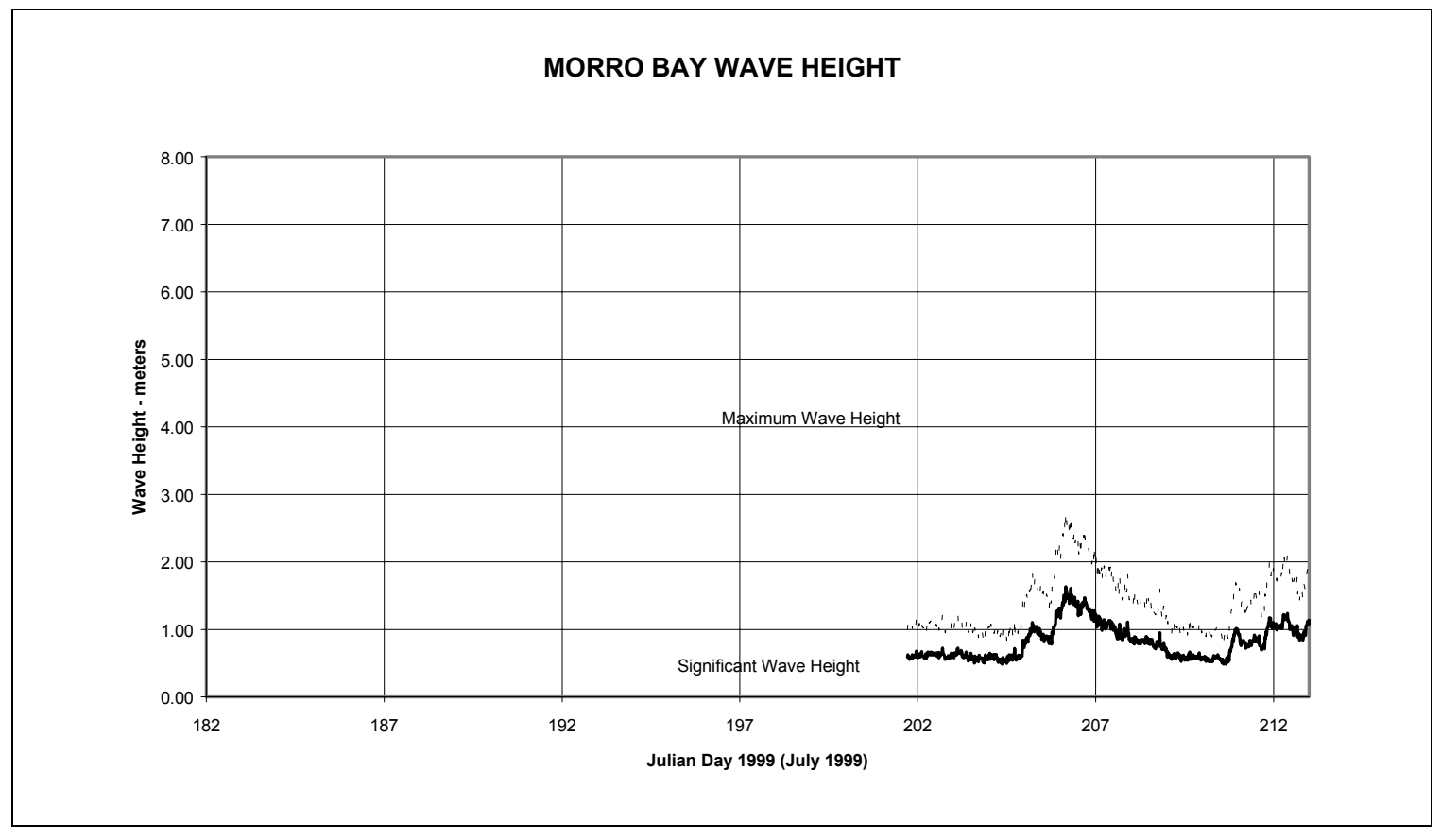

Figure 6. July 1999 maximum and significant wave heights

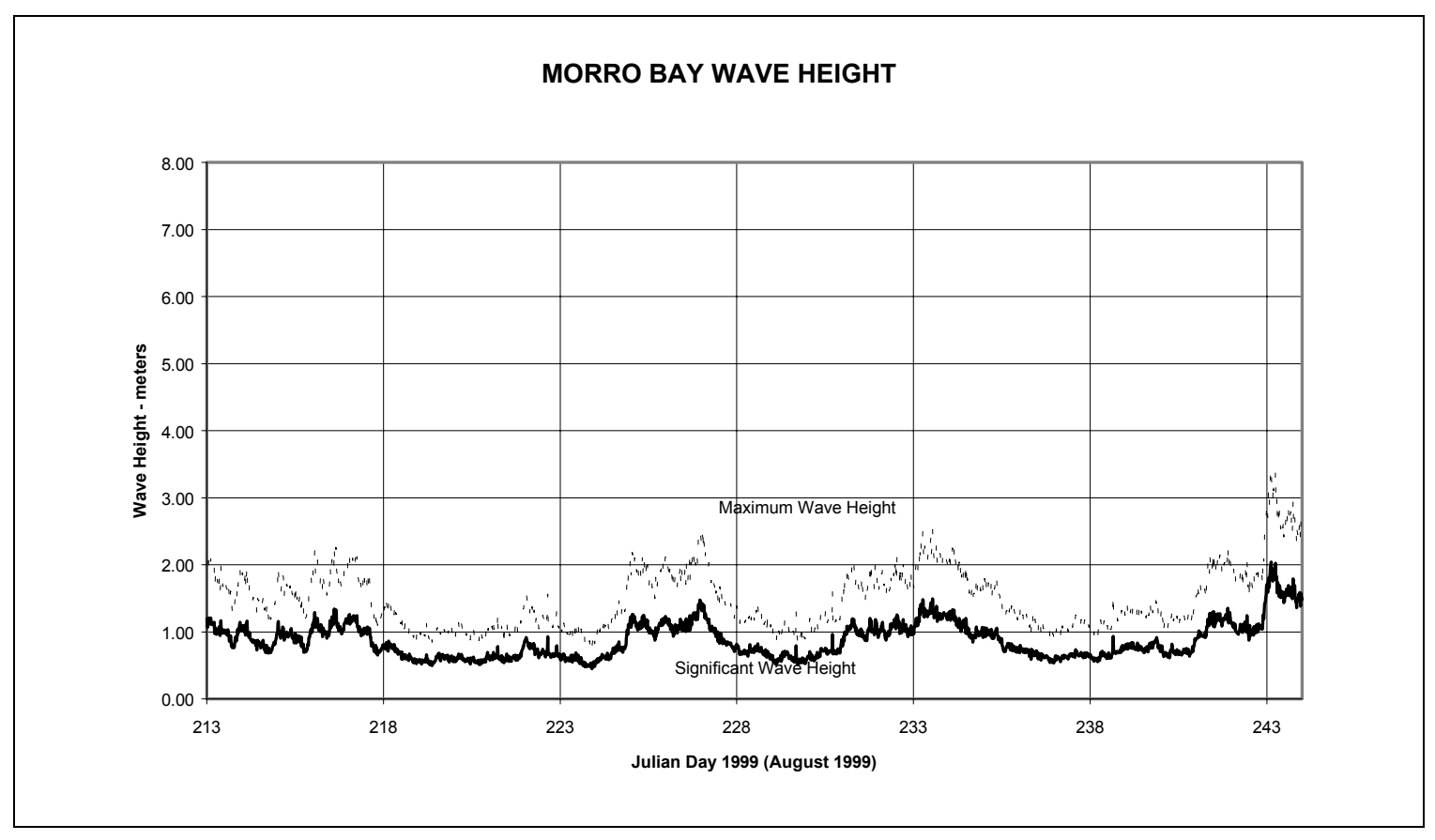

Figure 7. August 1999 maximum and significant wave heights 


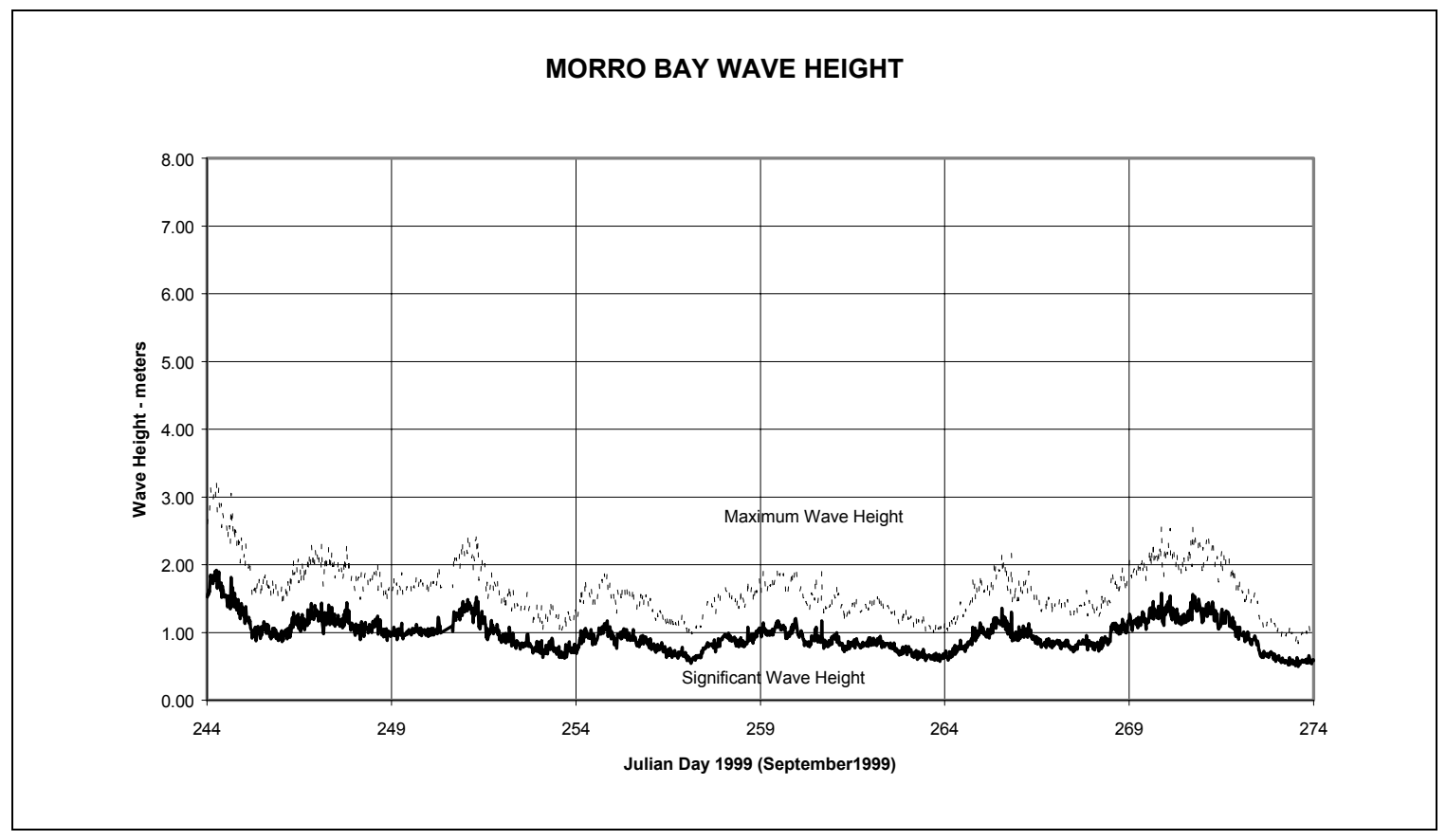

Figure 8. September 1999 maximum and significant wave heights

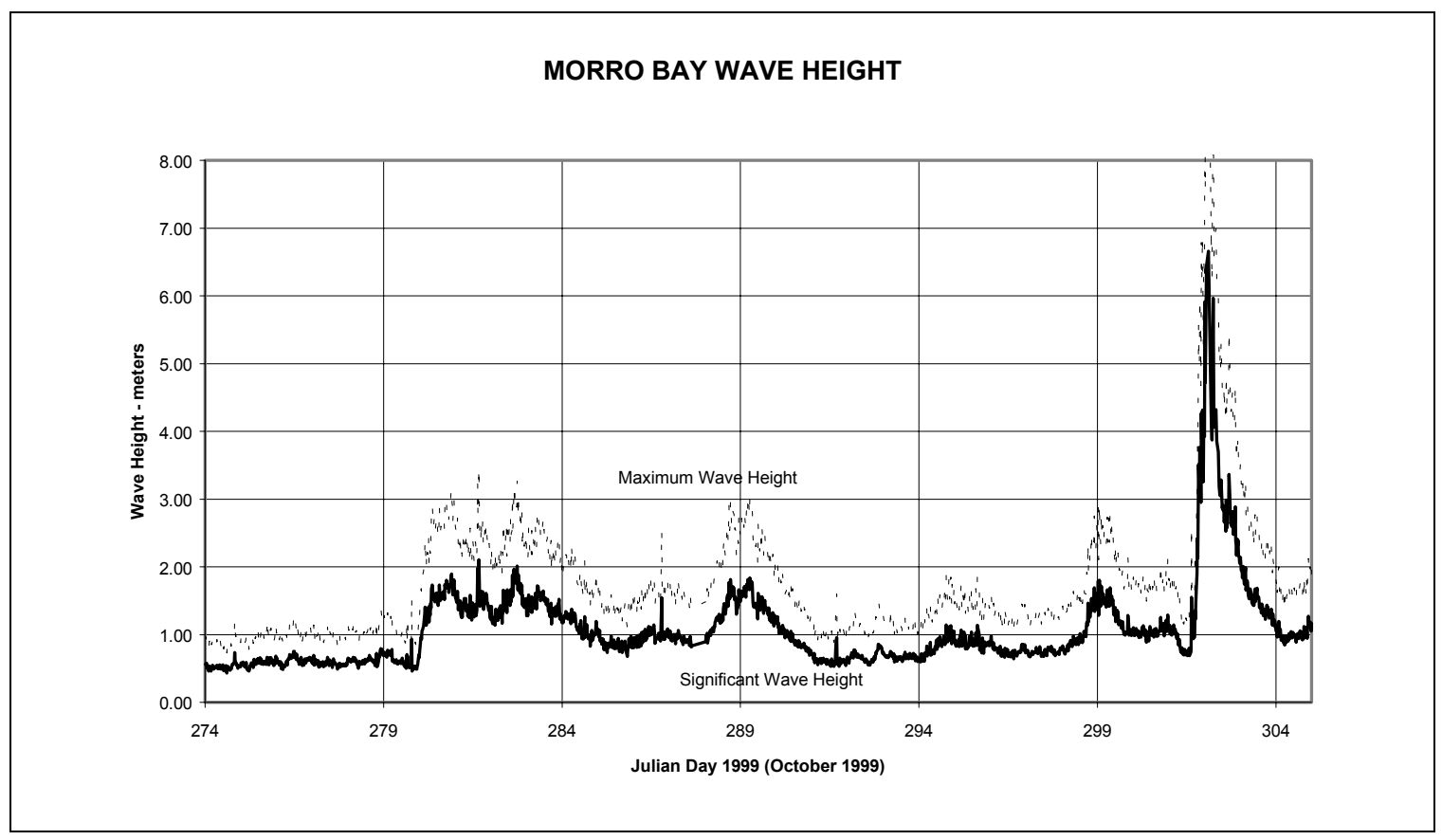

Figure 9. October 1999 maximum and significant wave heights 


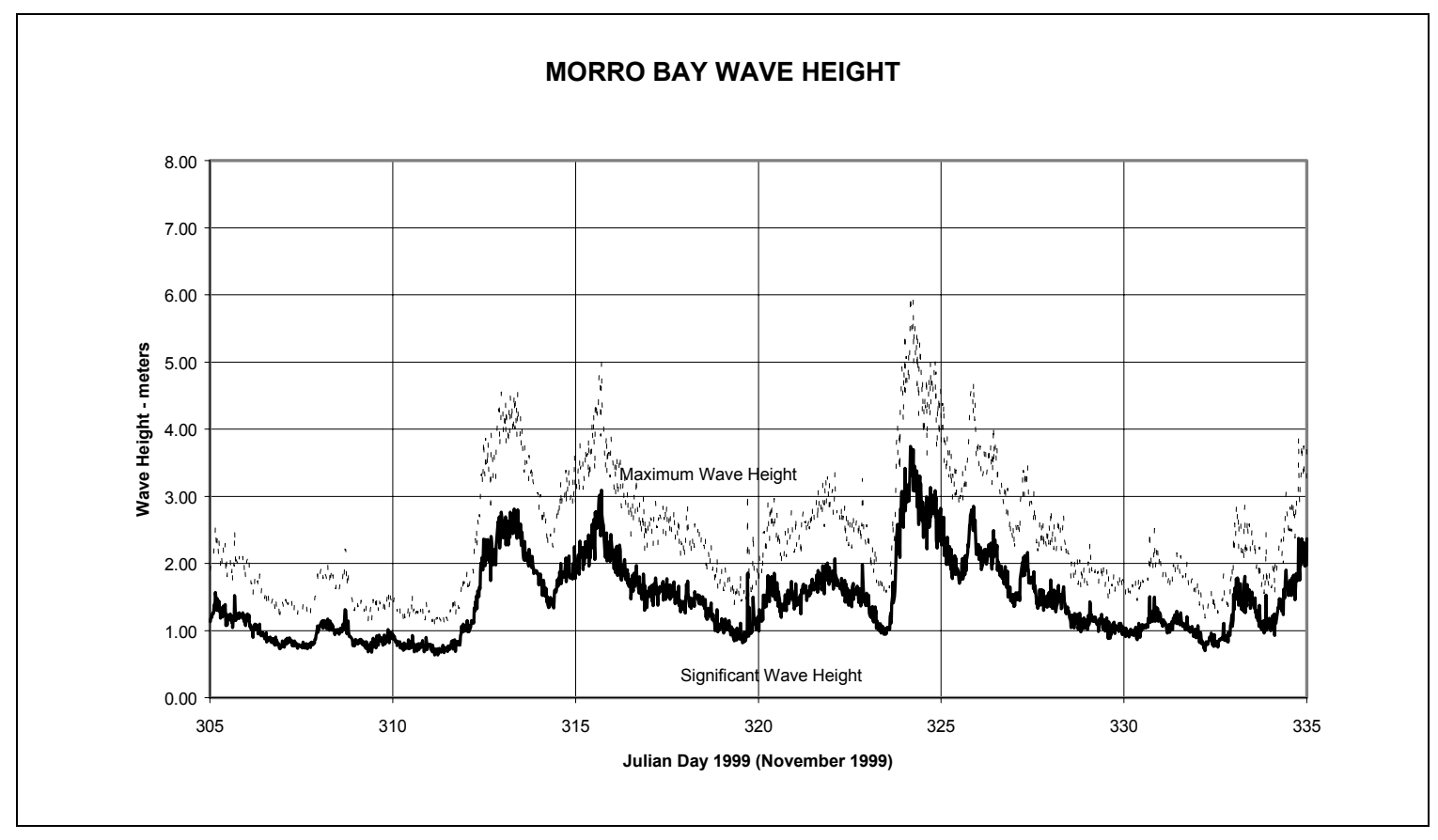

Figure 10. November 1999 maximum and significant wave heights

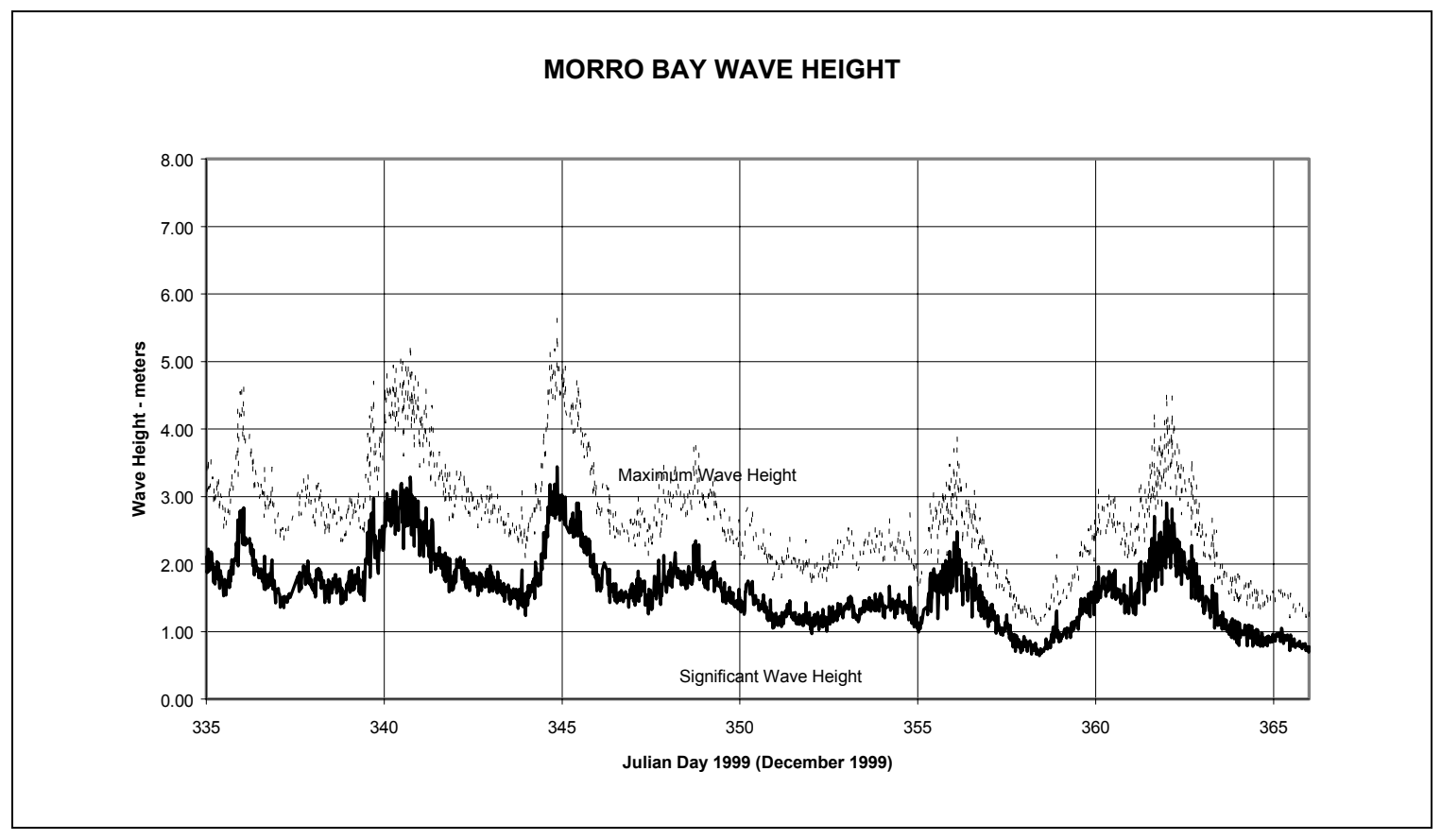

Figure 11. December 1999 maximum and significant wave heights 


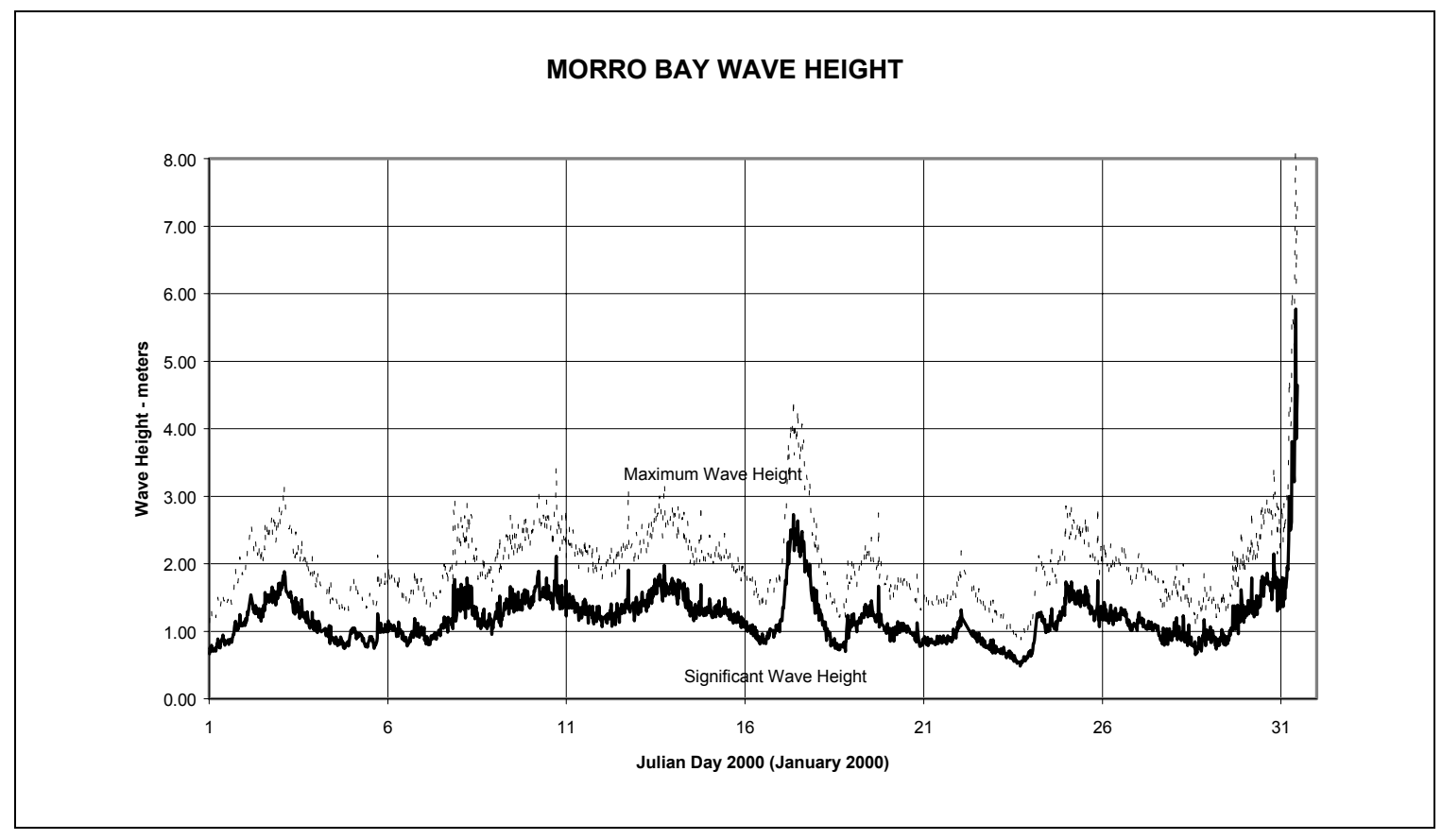

Figure 12. January 2000 maximum and significant wave heights

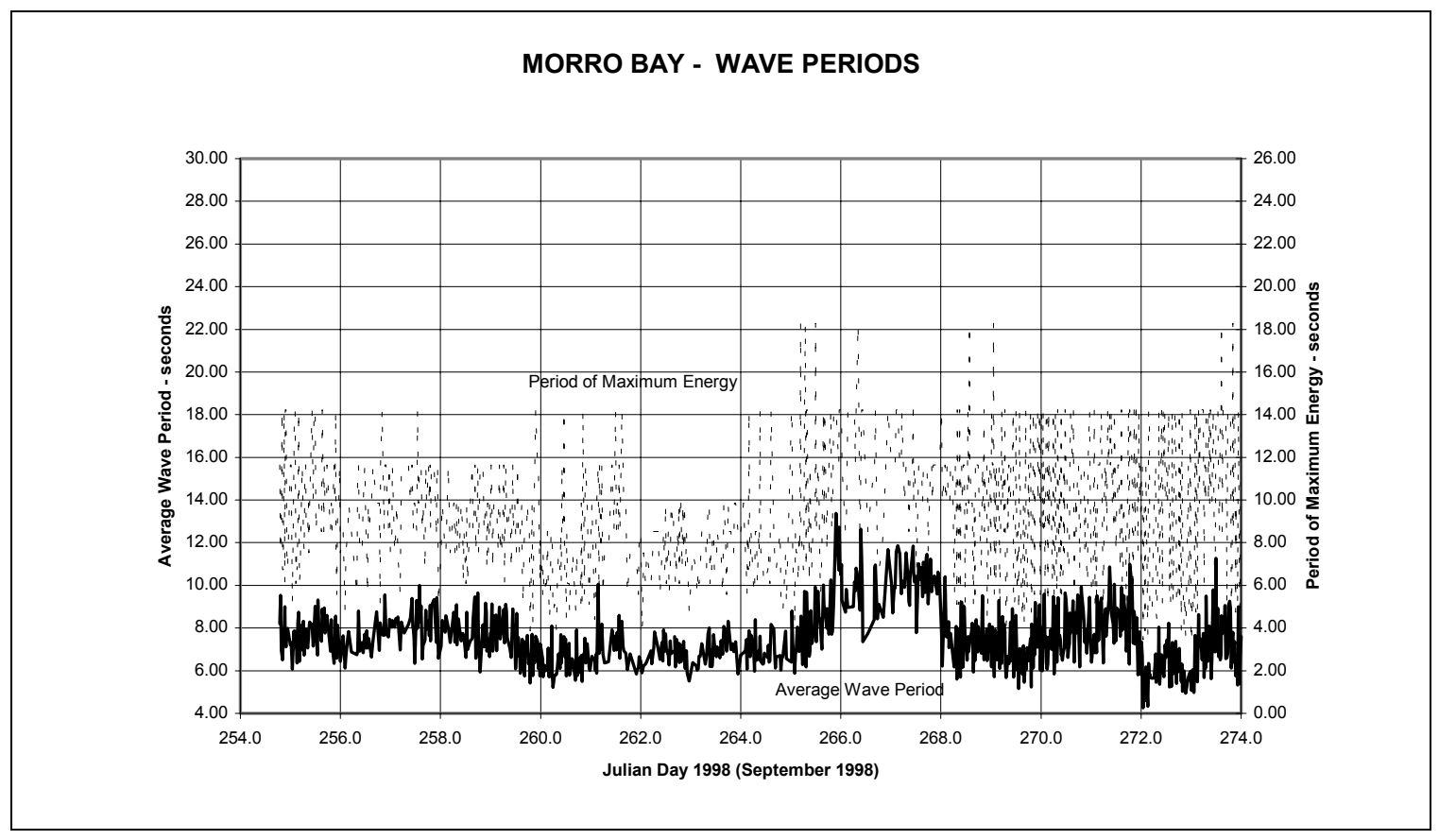

Figure 13. September 1998 average wave periods and periods of maximum energy 


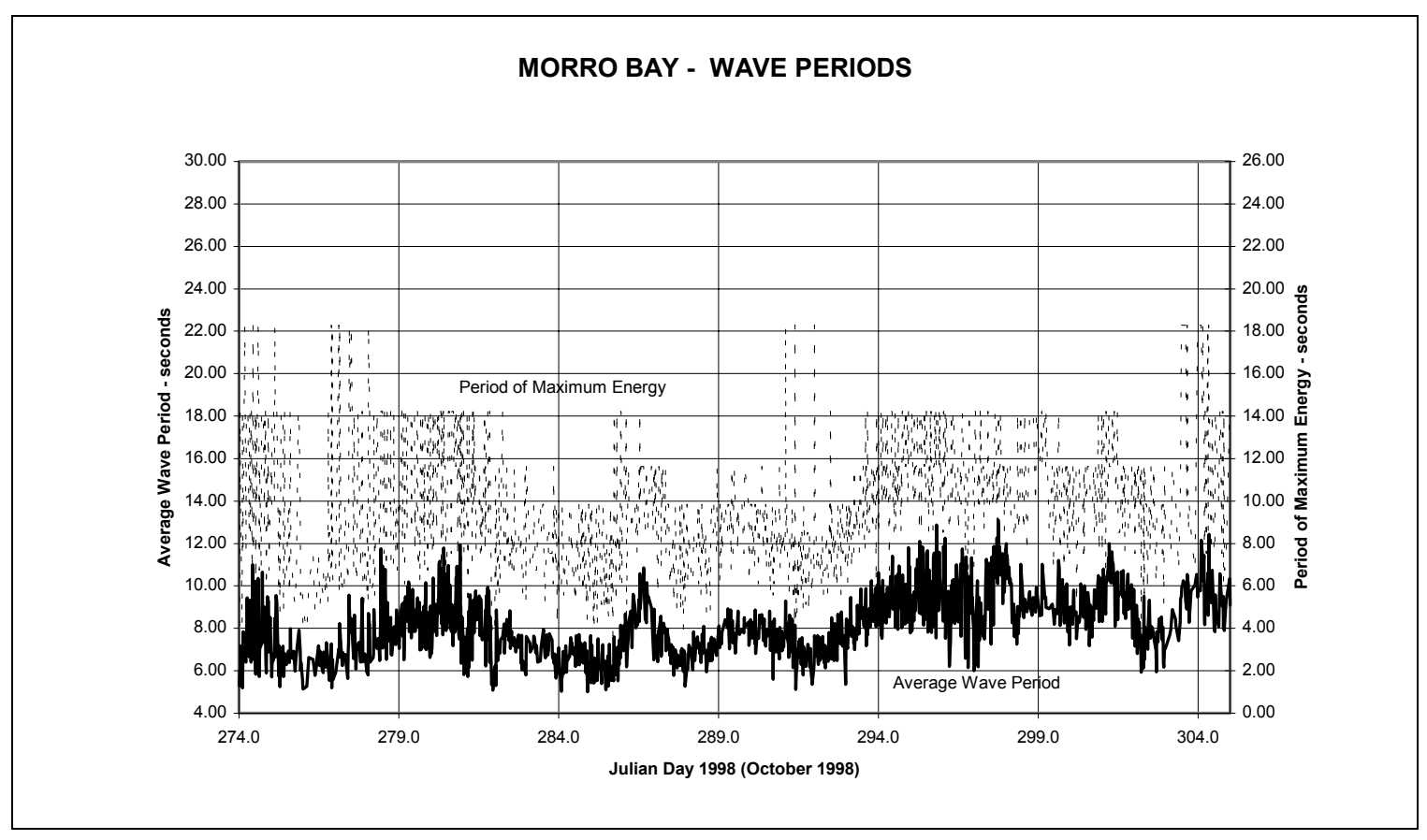

Figure 14. October 1998 average wave periods and periods of maximum energy

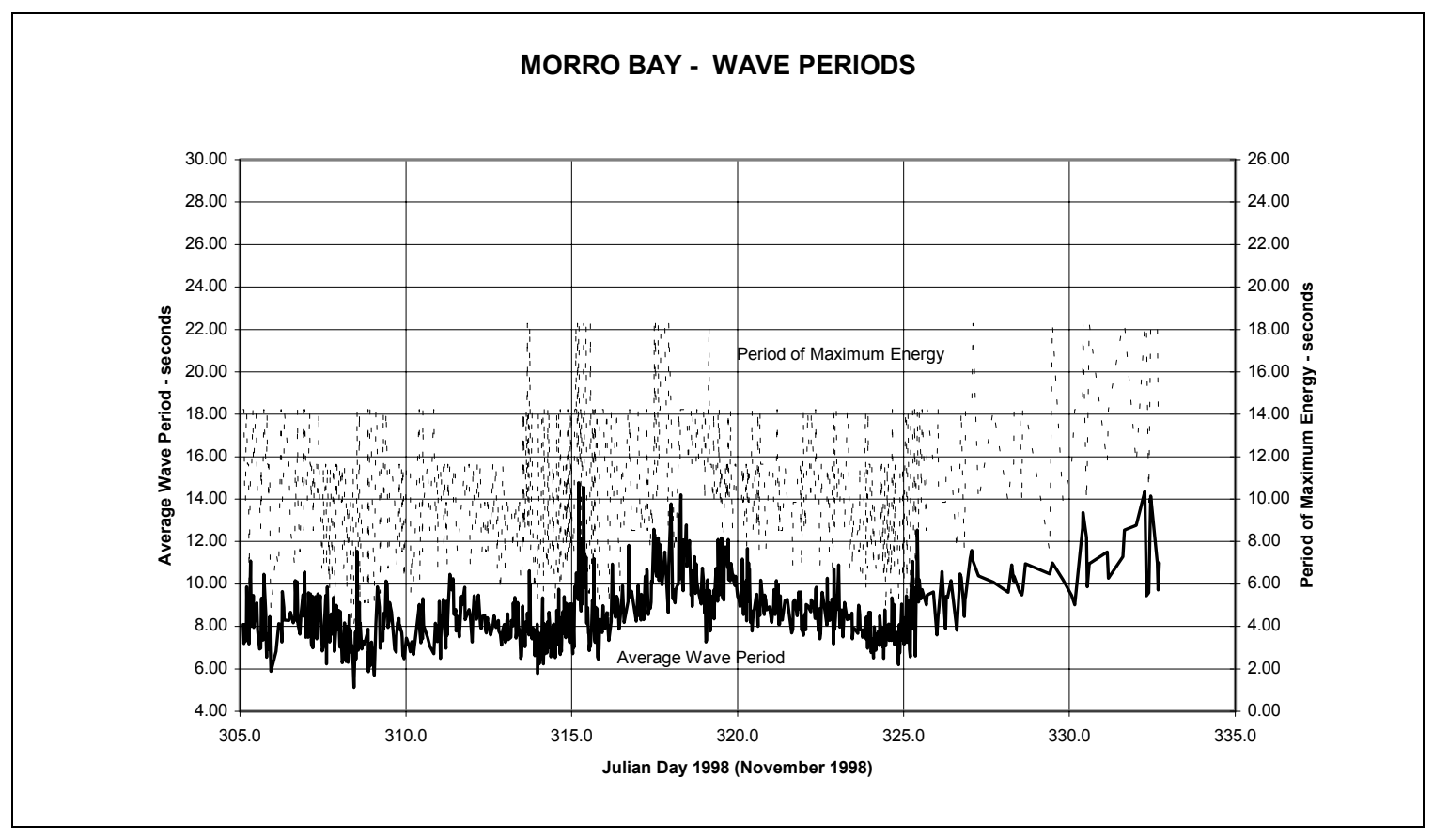

Figure 15. November 1998 average wave periods and periods of maximum energy 


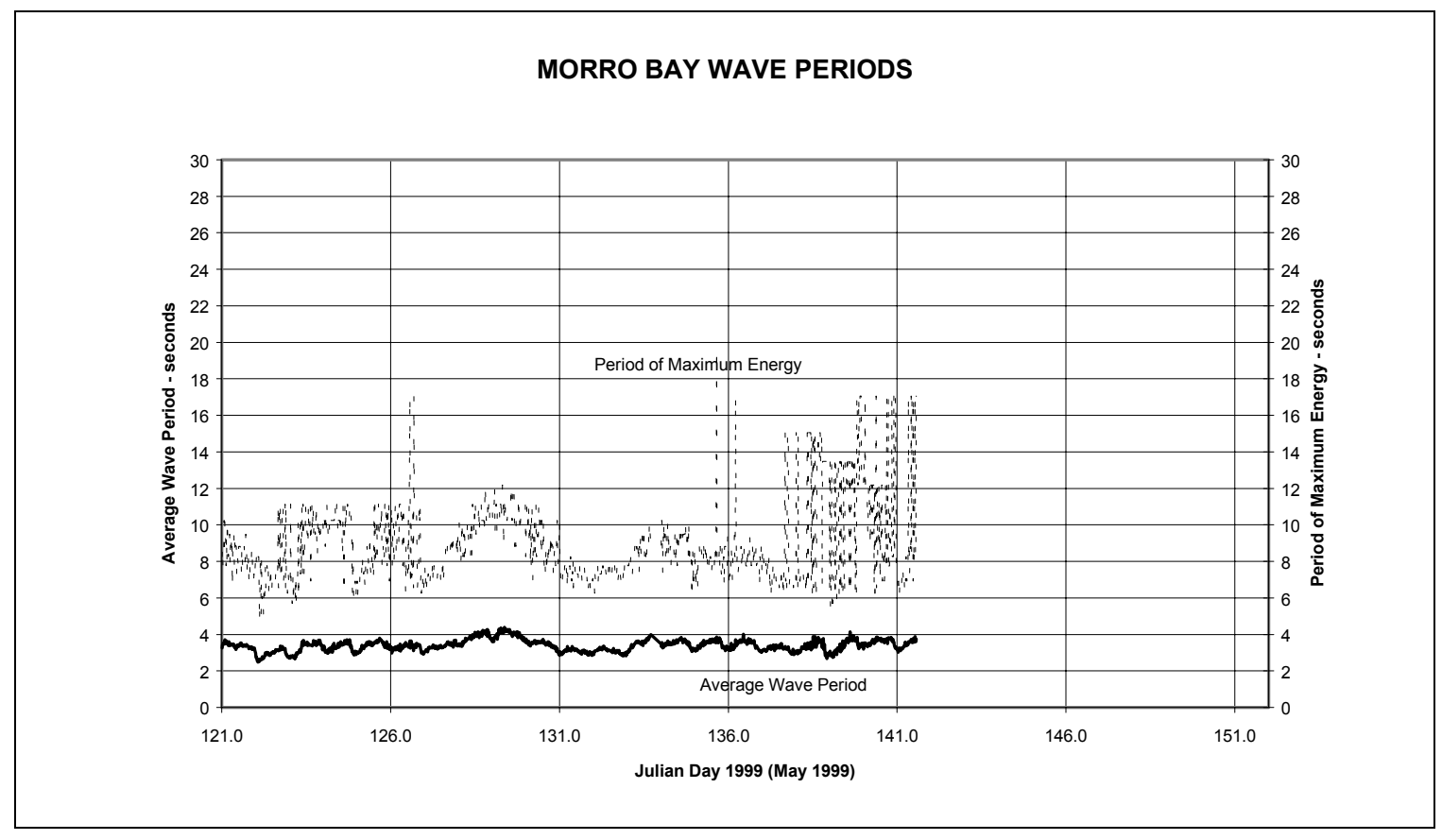

Figure 16. May 1999 average wave periods and periods of maximum energy

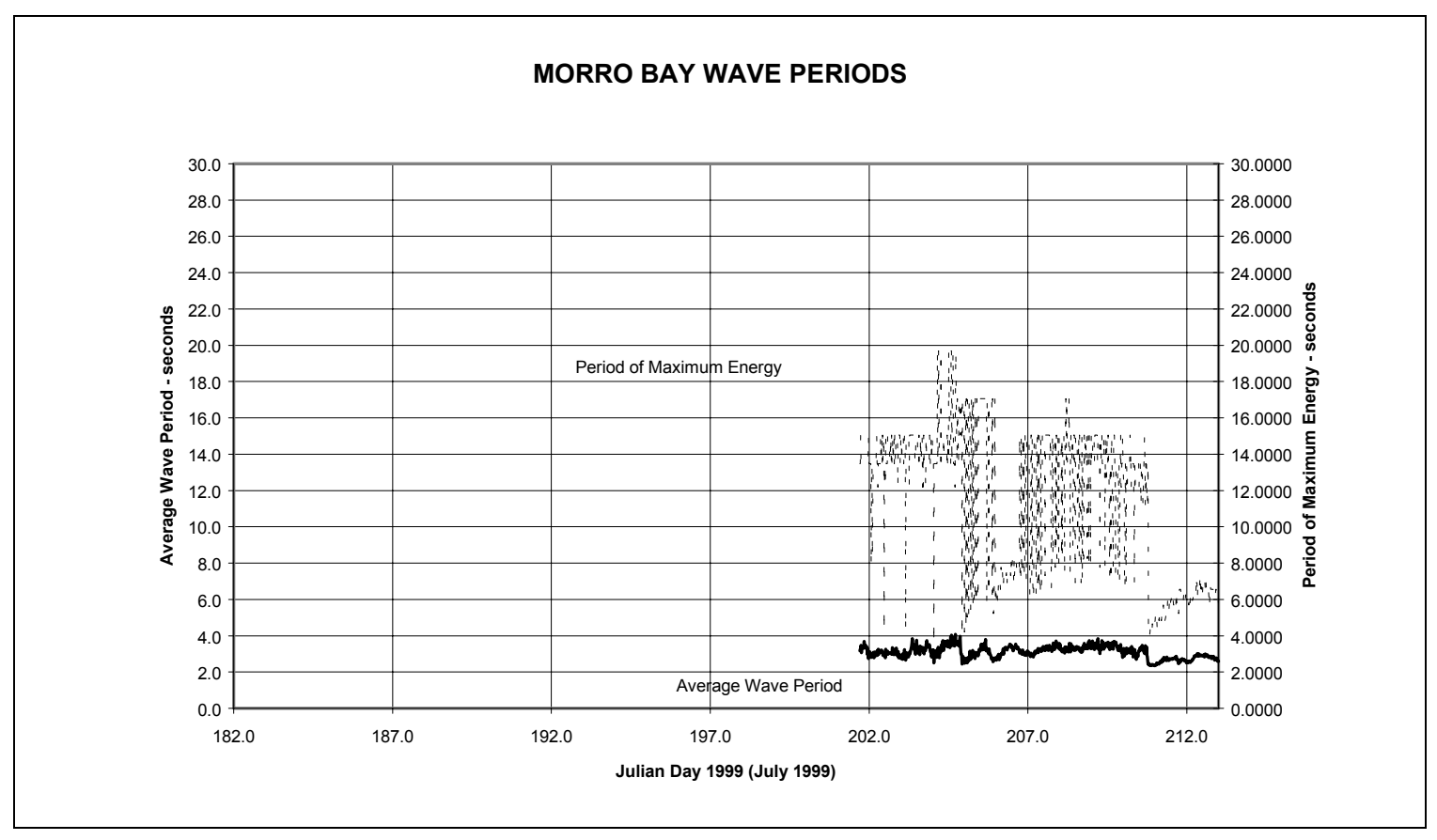

Figure 17. July 1999 average wave periods and periods of maximum energy 


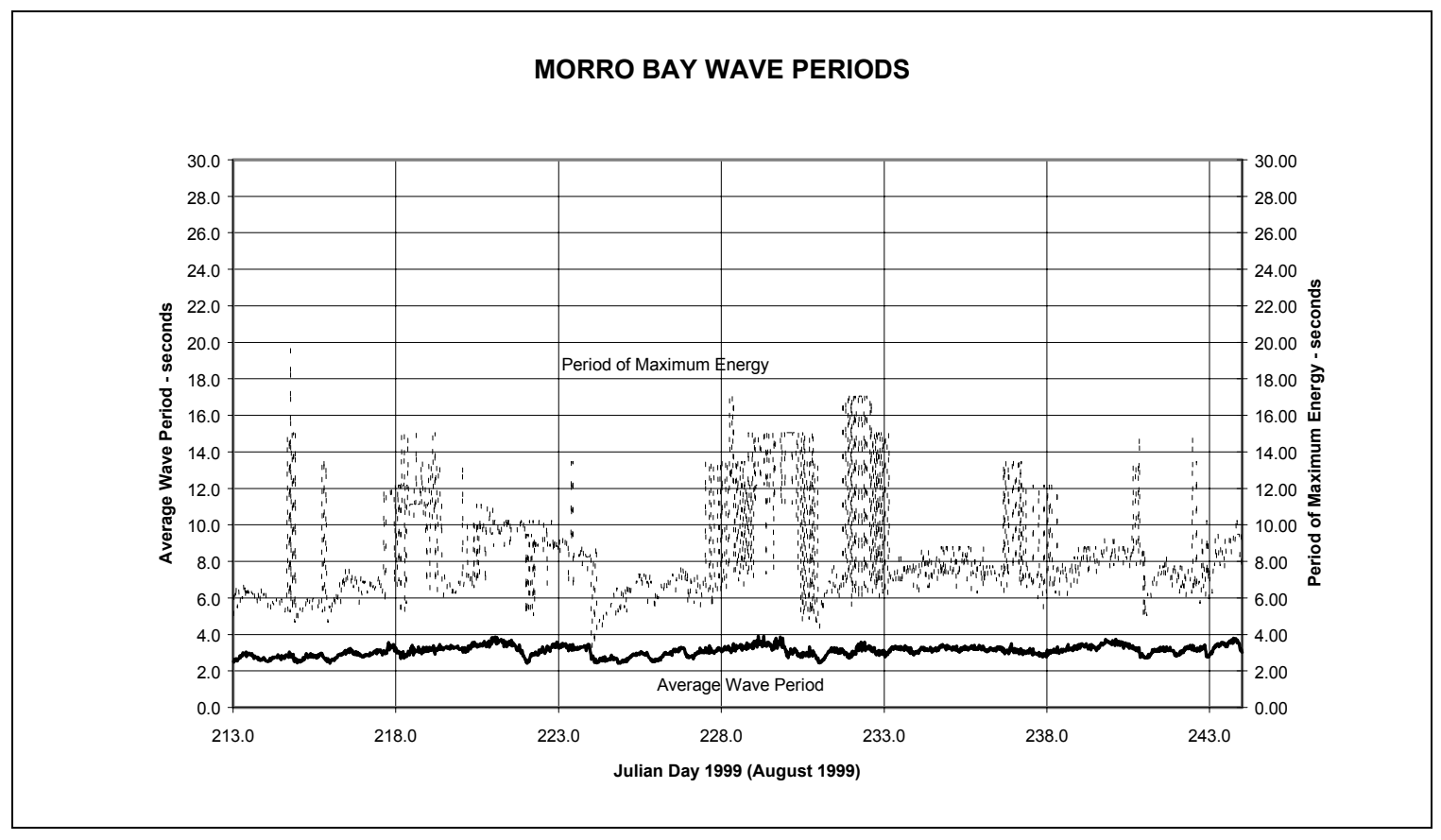

Figure 18. August 1999 average wave periods and periods of maximum energy

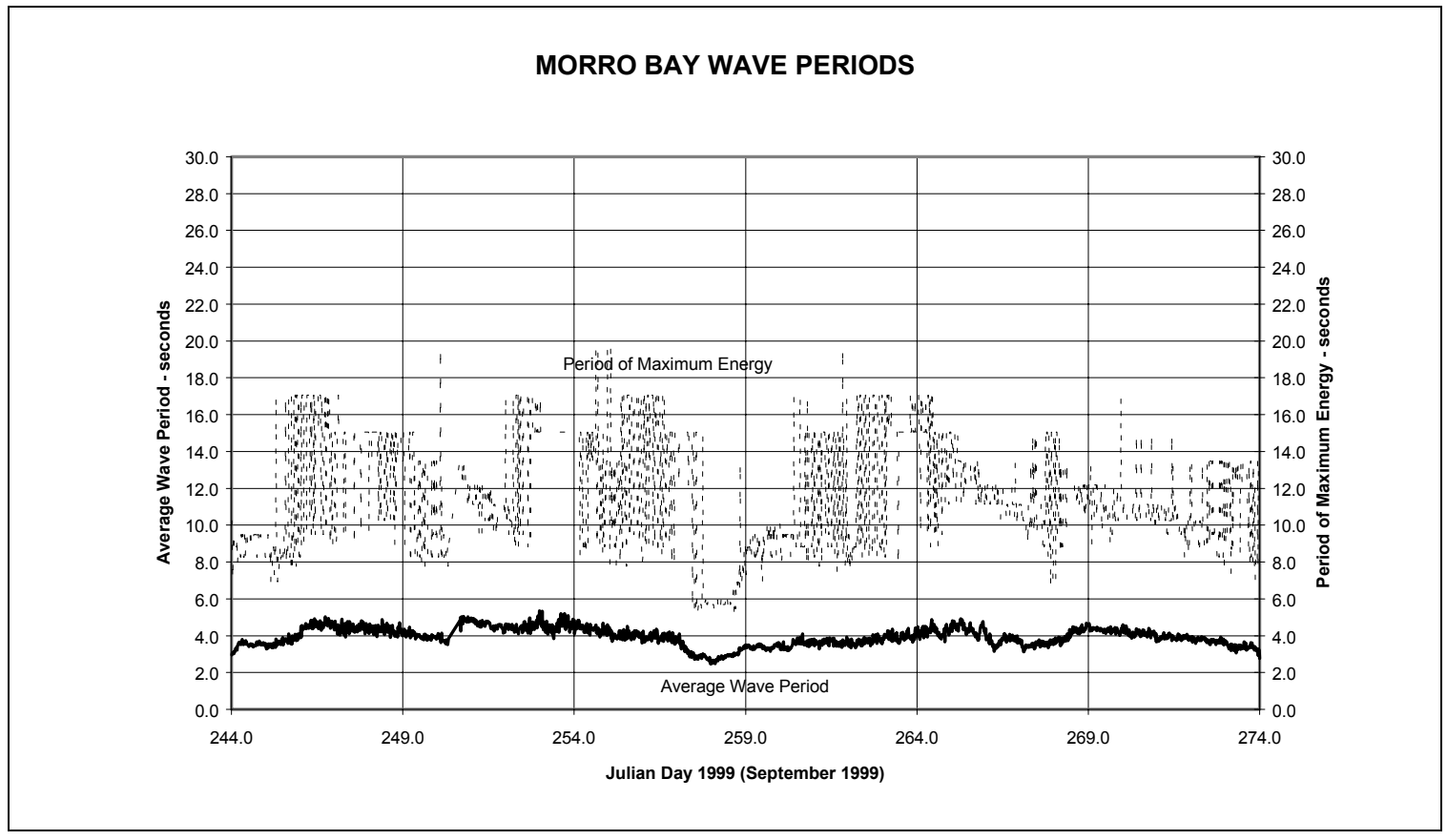

Figure 19. September 1999 average wave periods and periods of maximum energy 


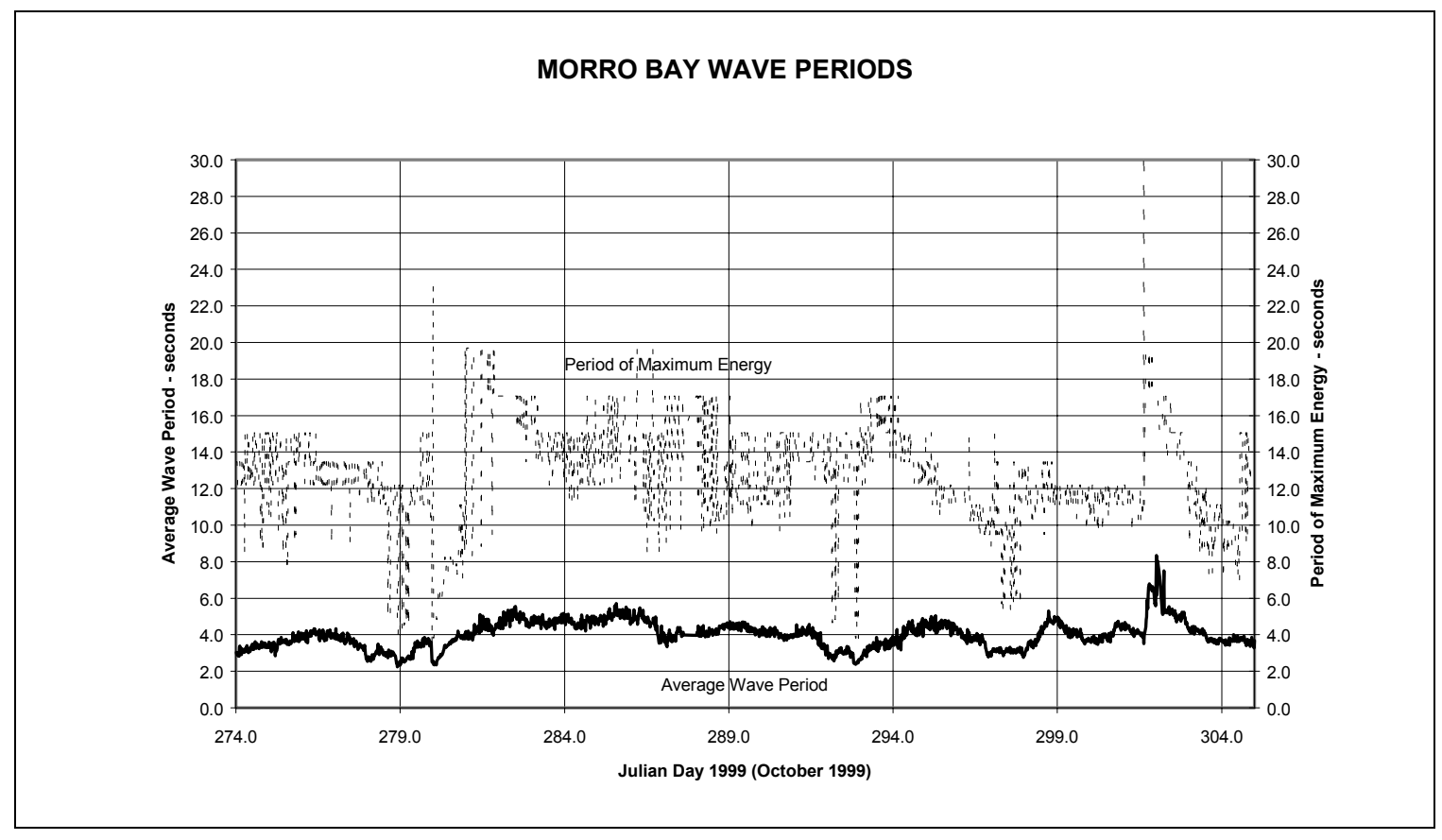

Figure 20. October 1999 average wave periods and periods of maximum energy

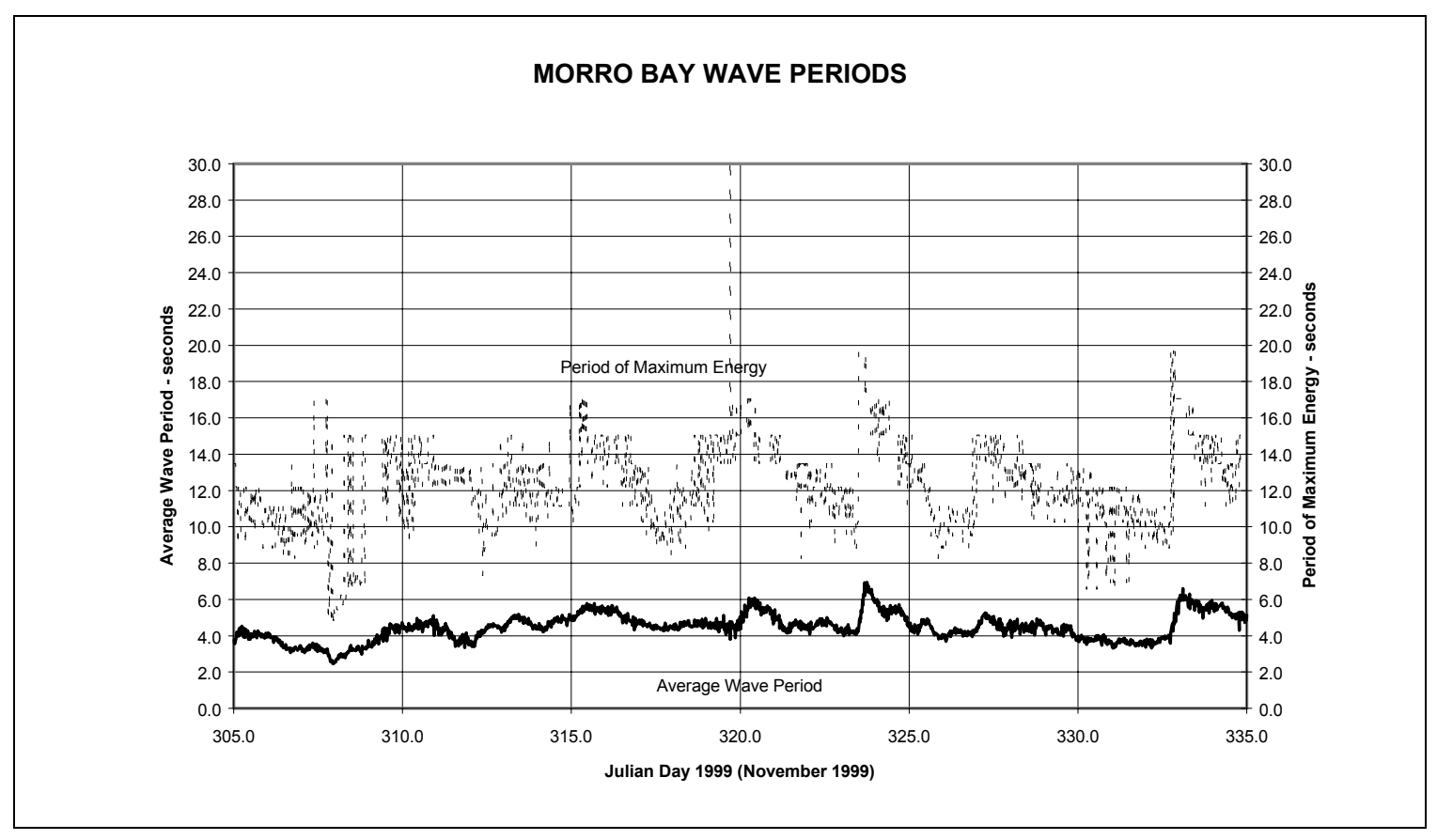

Figure 21. November 1999 average wave periods and periods of maximum energy 


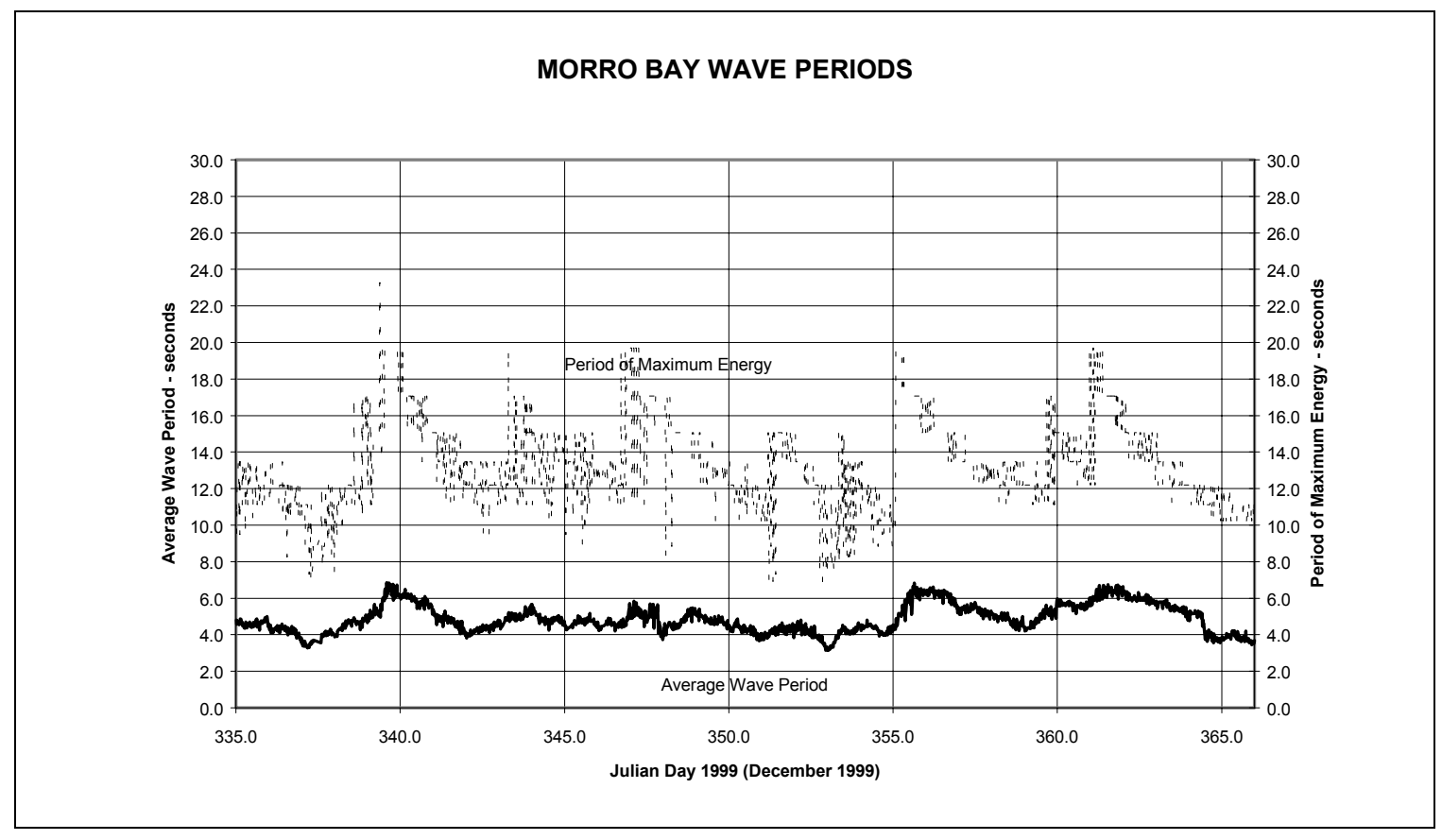

Figure 22. December 1999 average wave periods and periods of maximum energy

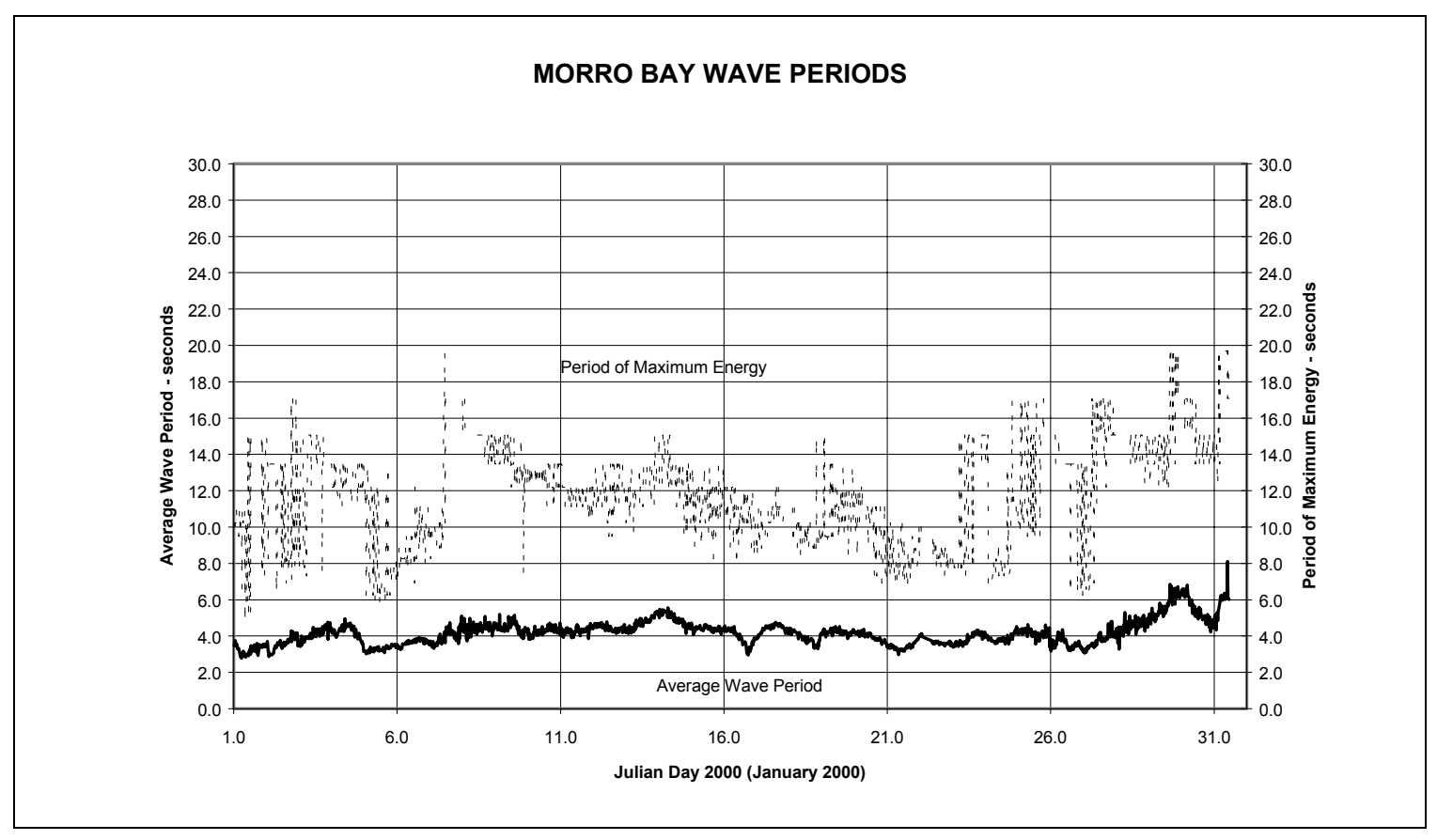

Figure 23. January 2000 average wave periods and periods of maximum energy 


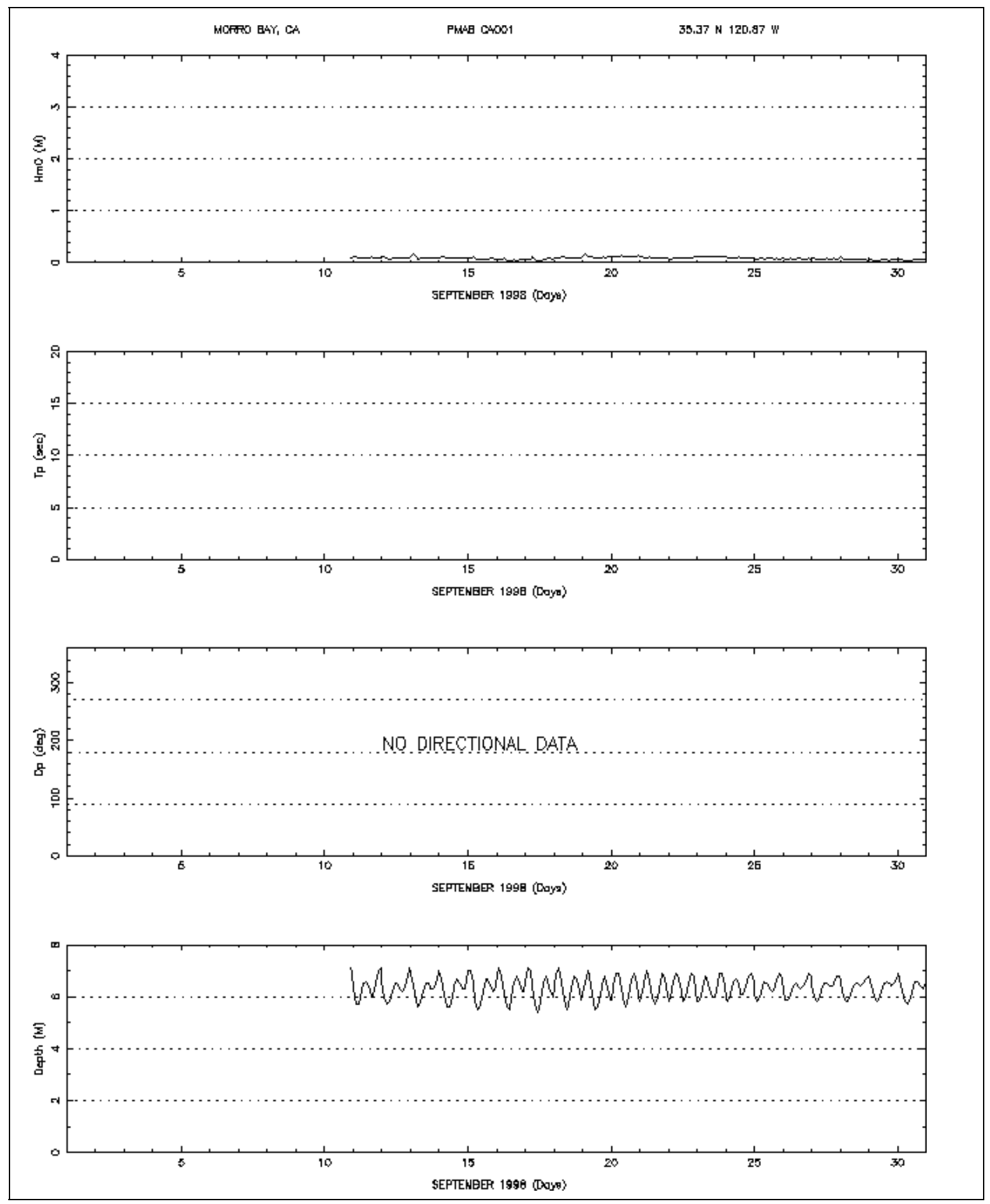

Figure 24. September 1998 monthly time series (CA001) 

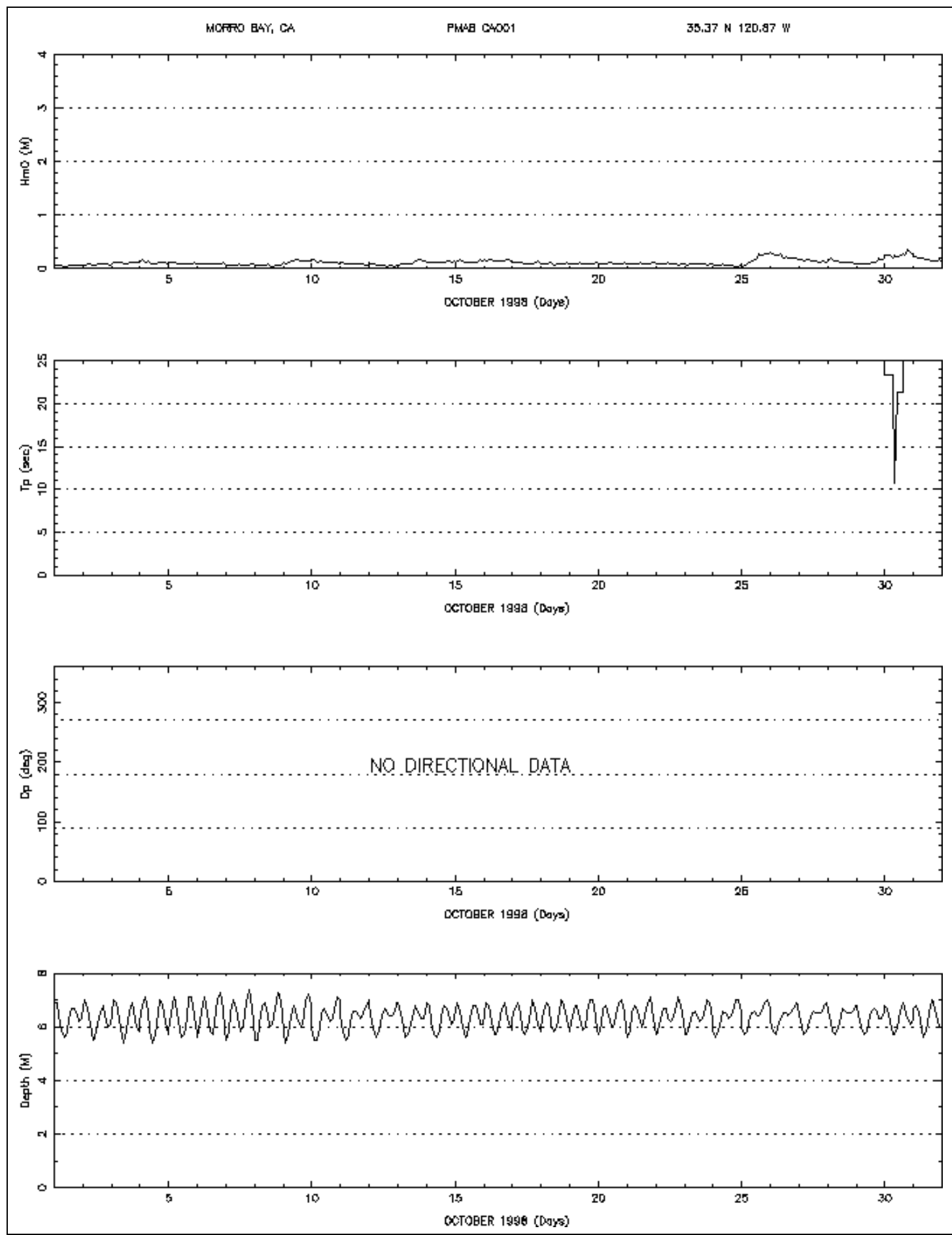

Figure 25. October 1998 monthly time series (CA001) 


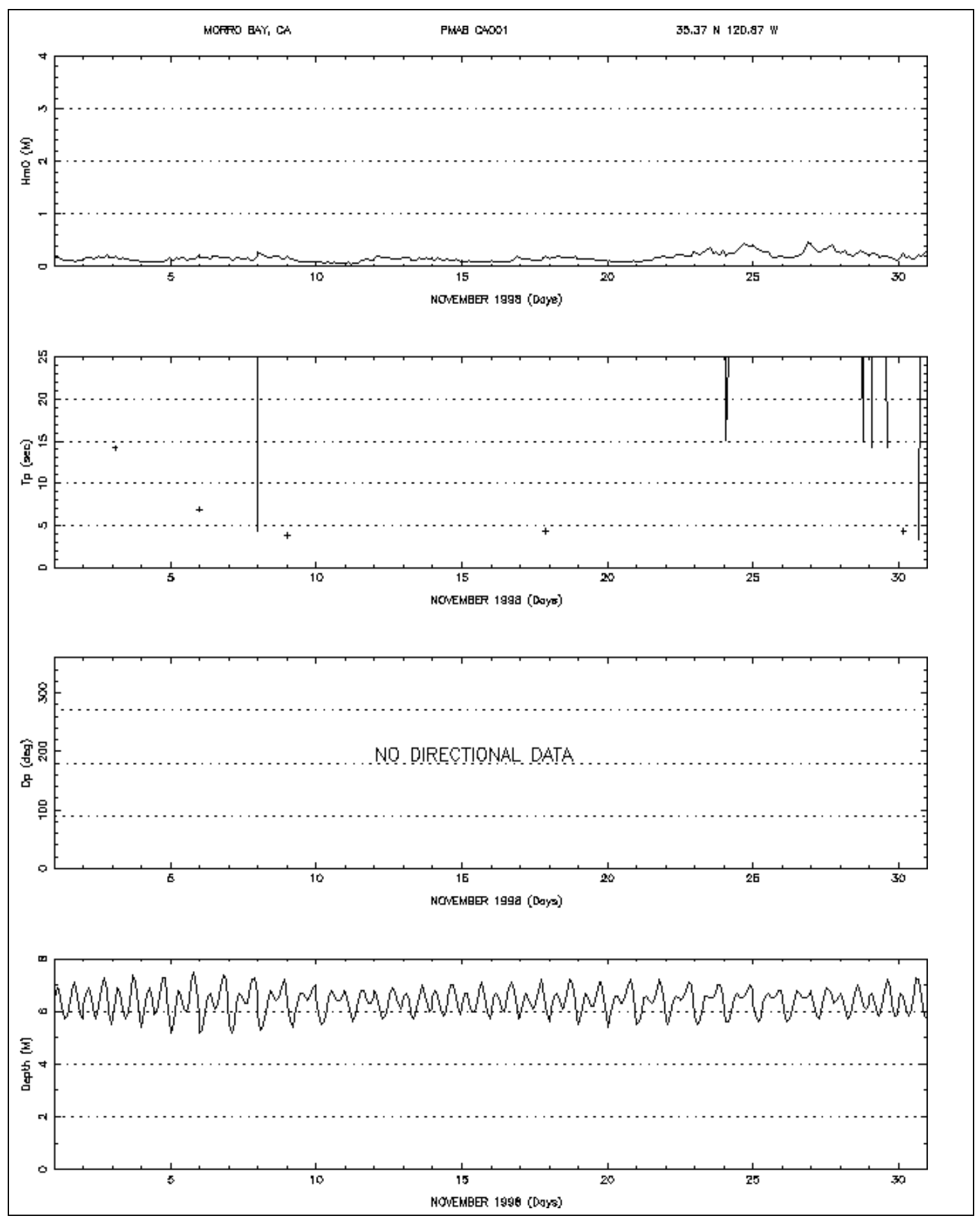

Figure 26. November 1998 monthly time series (CA001) 


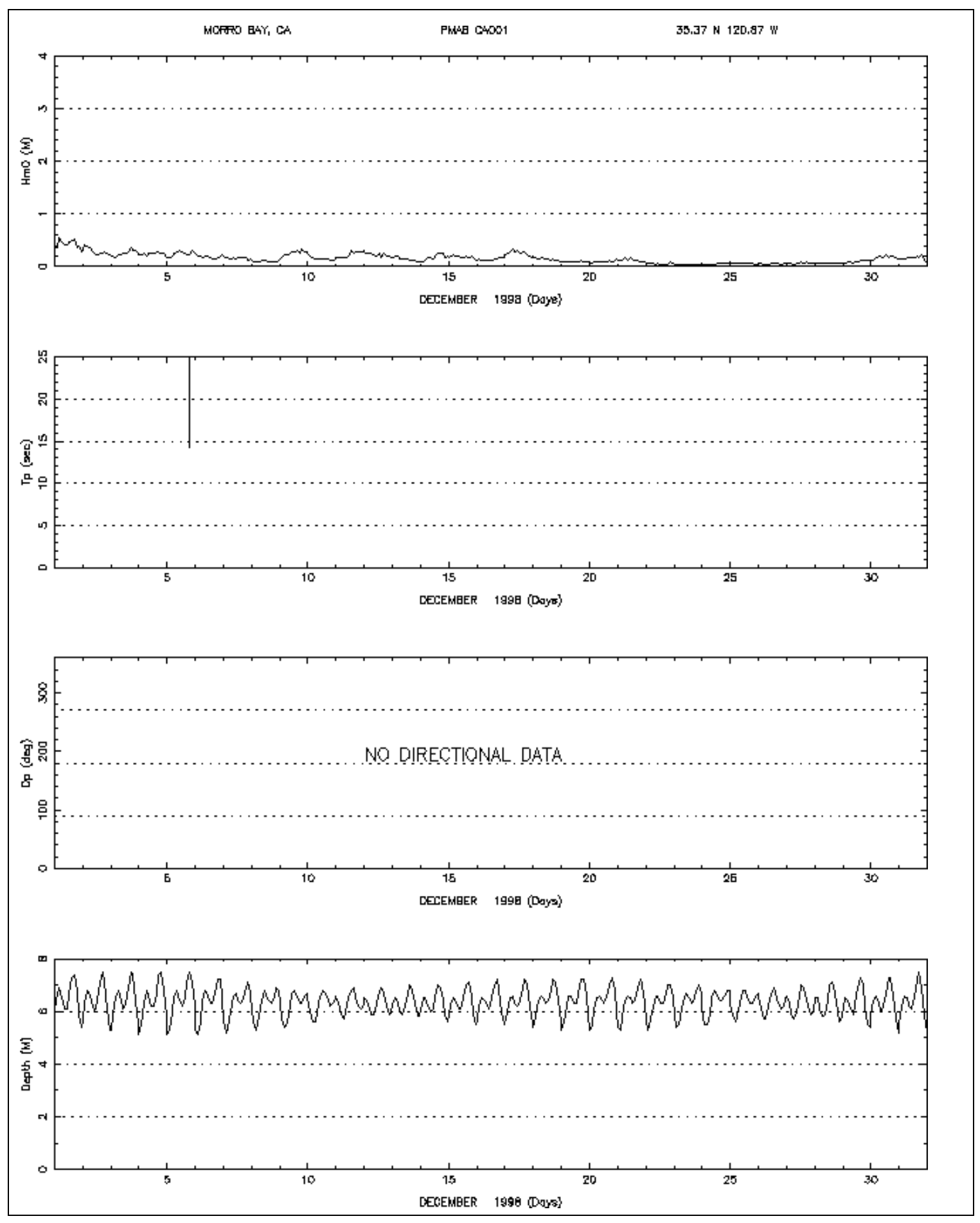

Figure 27. December 1998 monthly time series (CA001) 

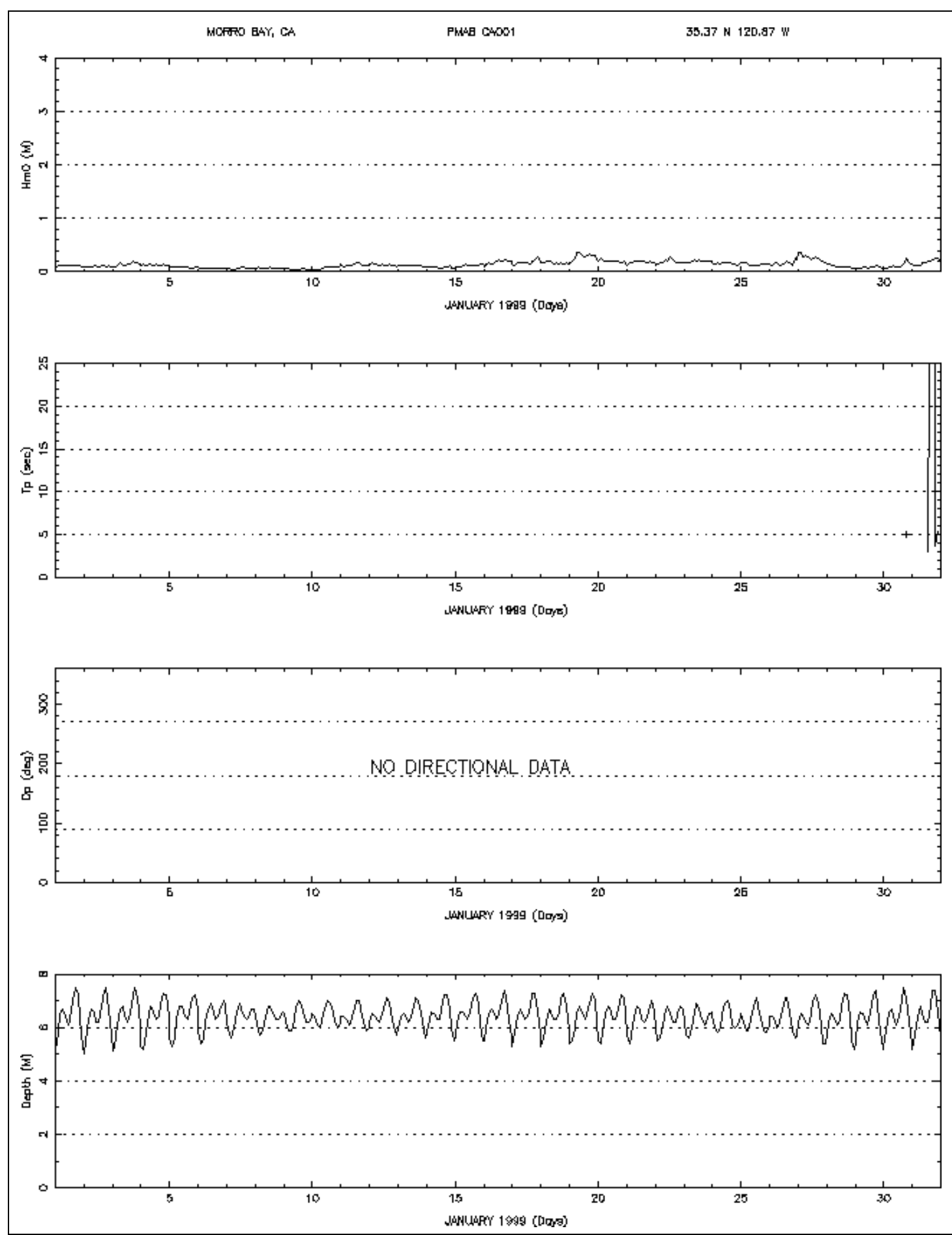

Figure 28. January 1999 monthly time series (CA001) 

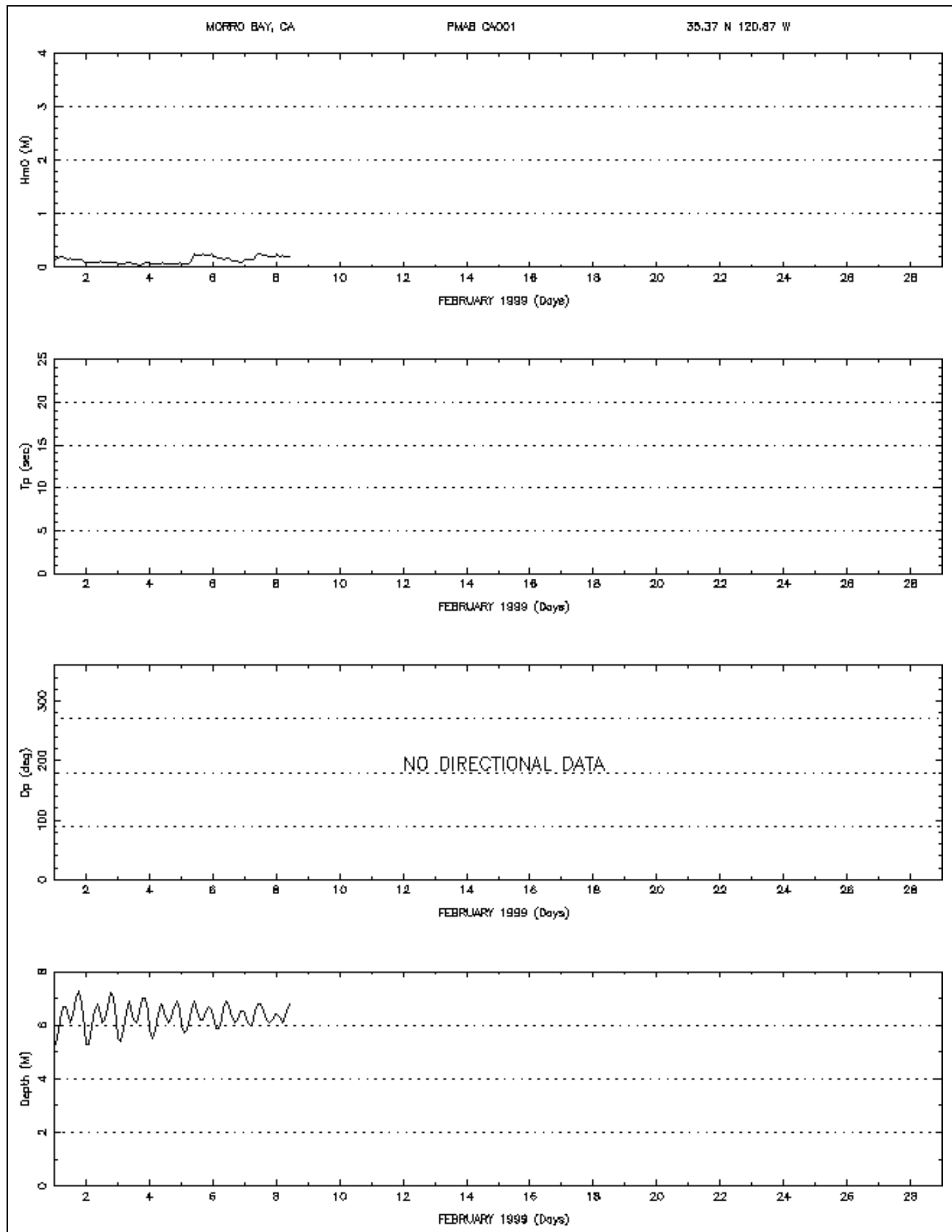

Figure 29. February 1999 monthly time series (CA001) 

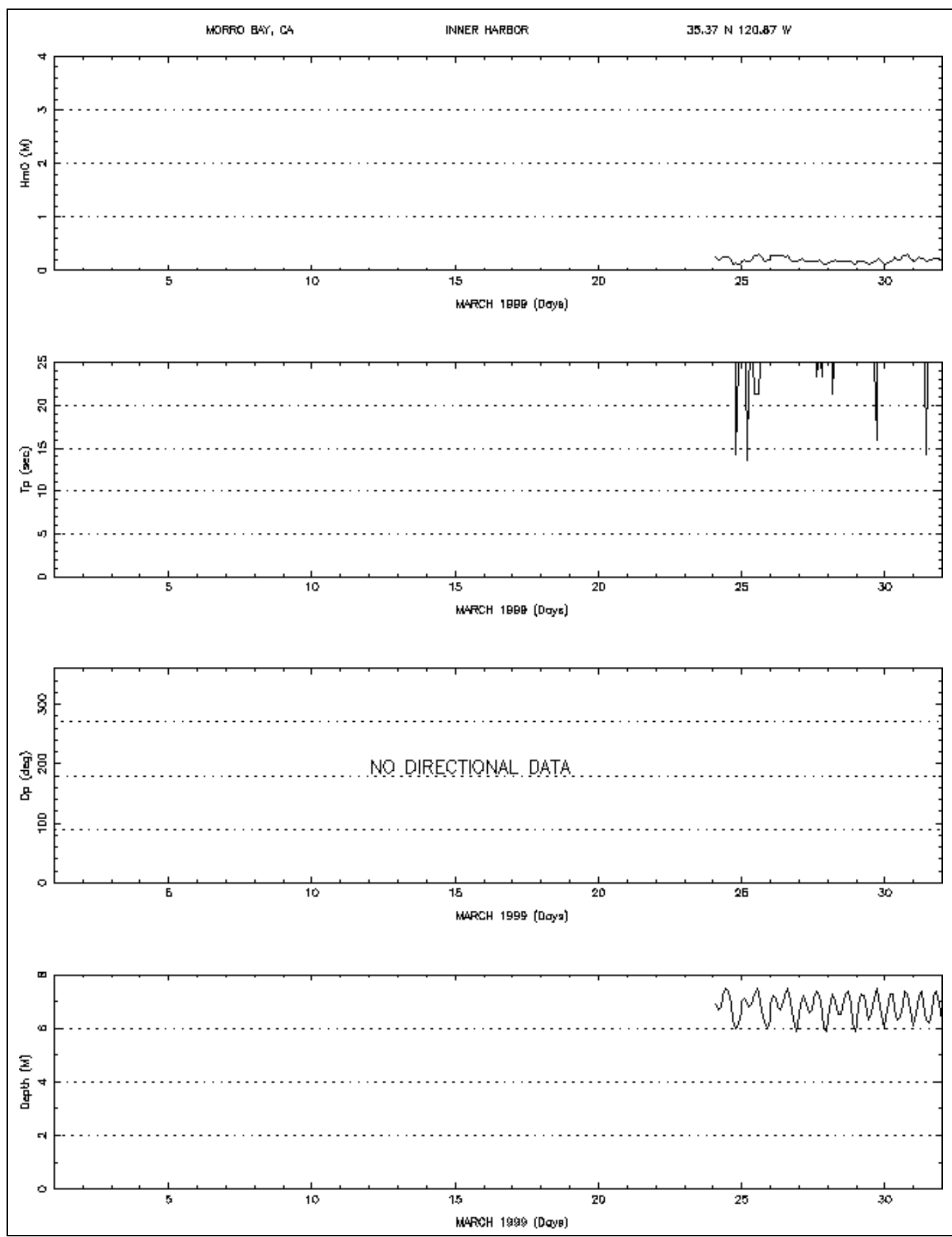

Figure 30. March 1999 monthly time series (CA001) 

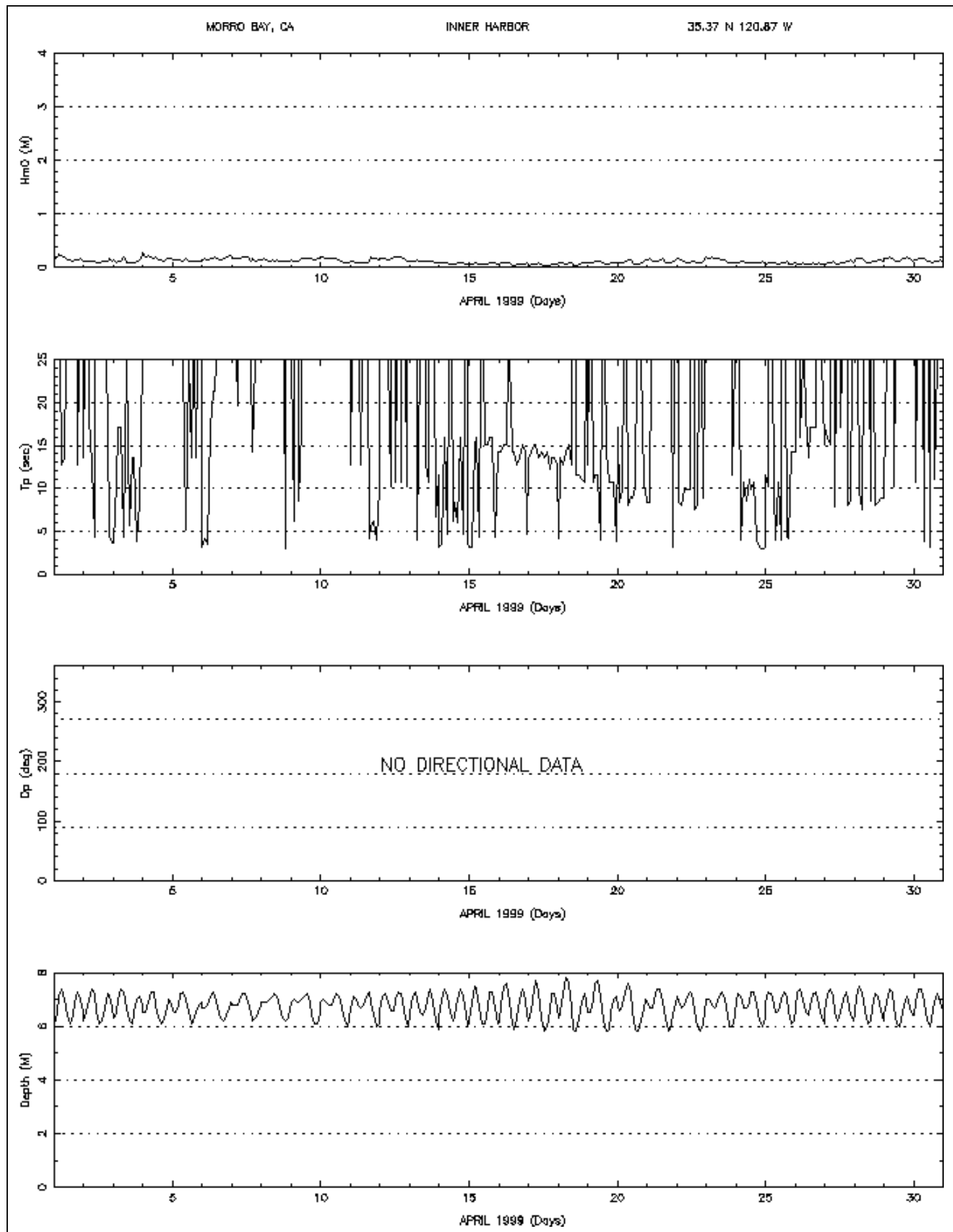

Figure 31. April 1999 monthly time series (CA001) 

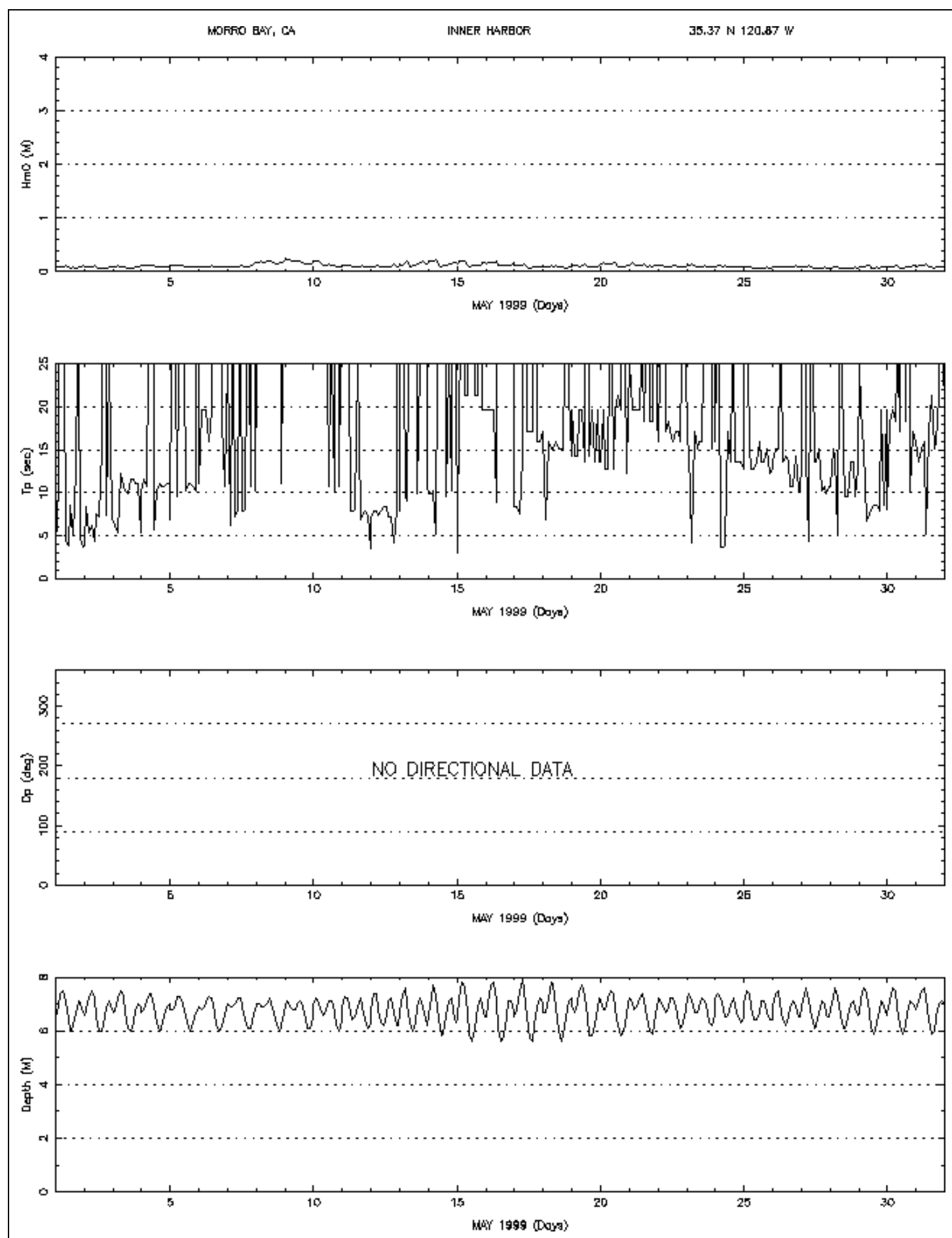

Figure 32. May 1999 monthly time series (CA001) 

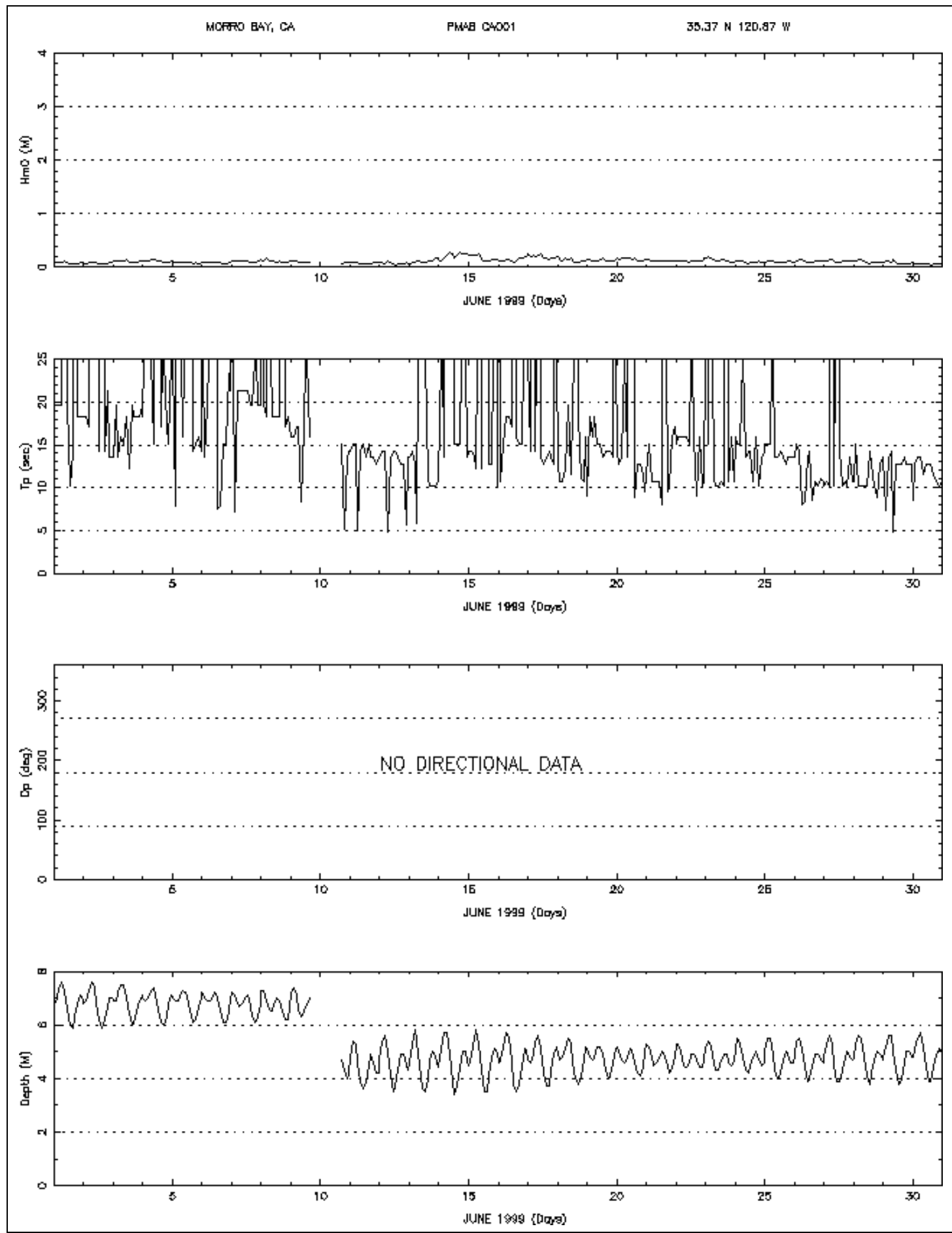

Figure 33. June 1999 monthly time series (CA001) 

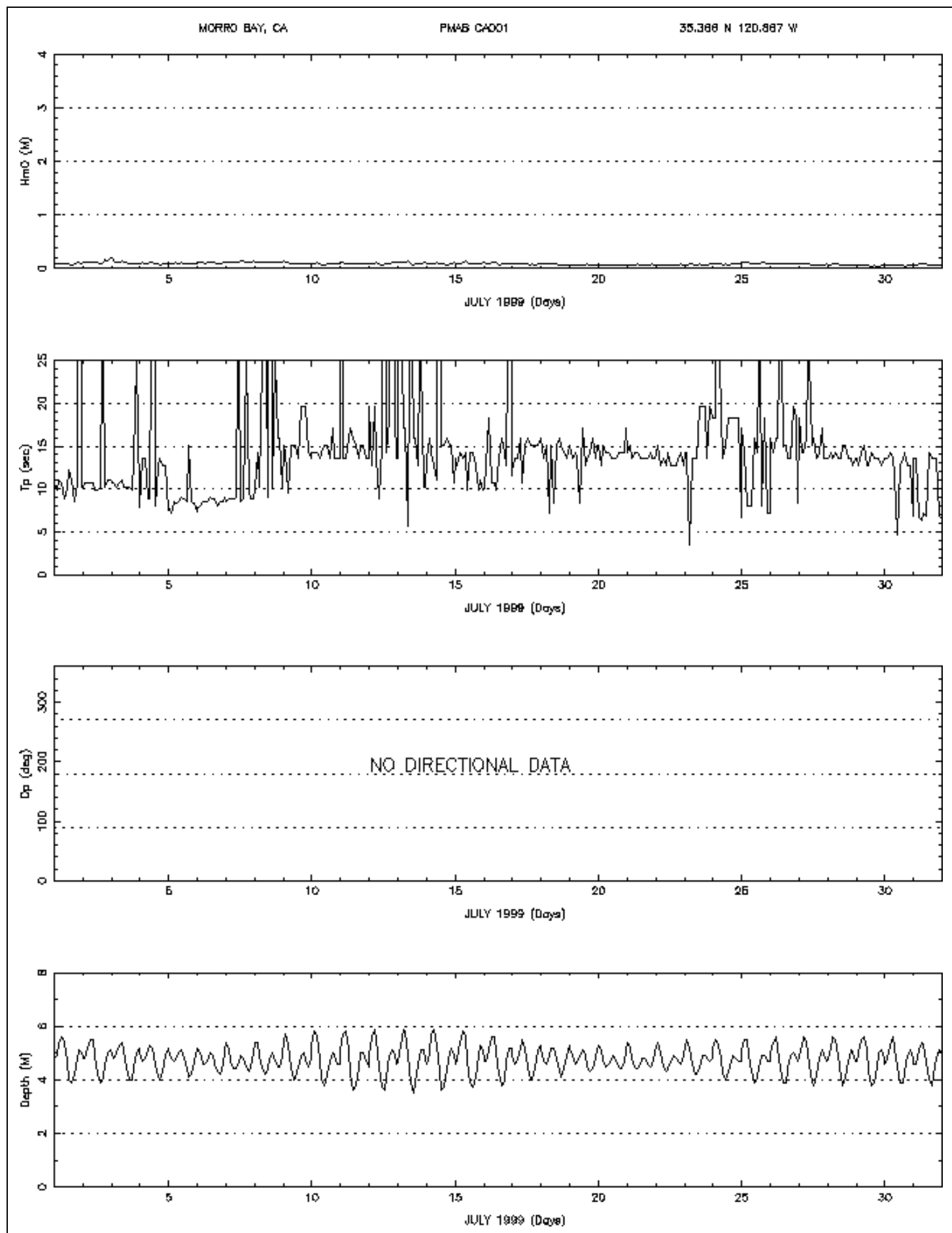

Figure 34. July 1999 monthly time series (CA001) 

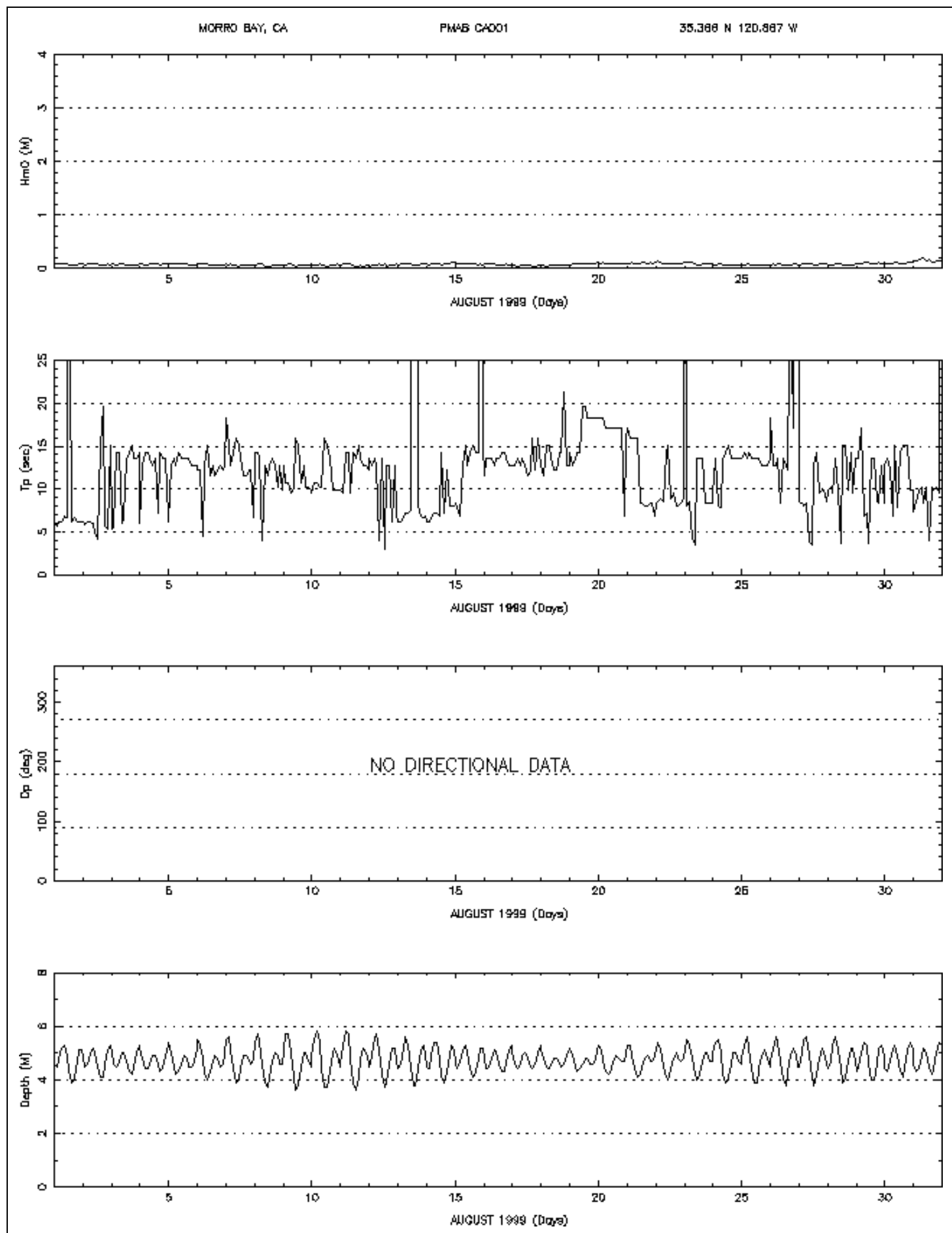

Figure 35. August 1999 monthly time series (CA001) 

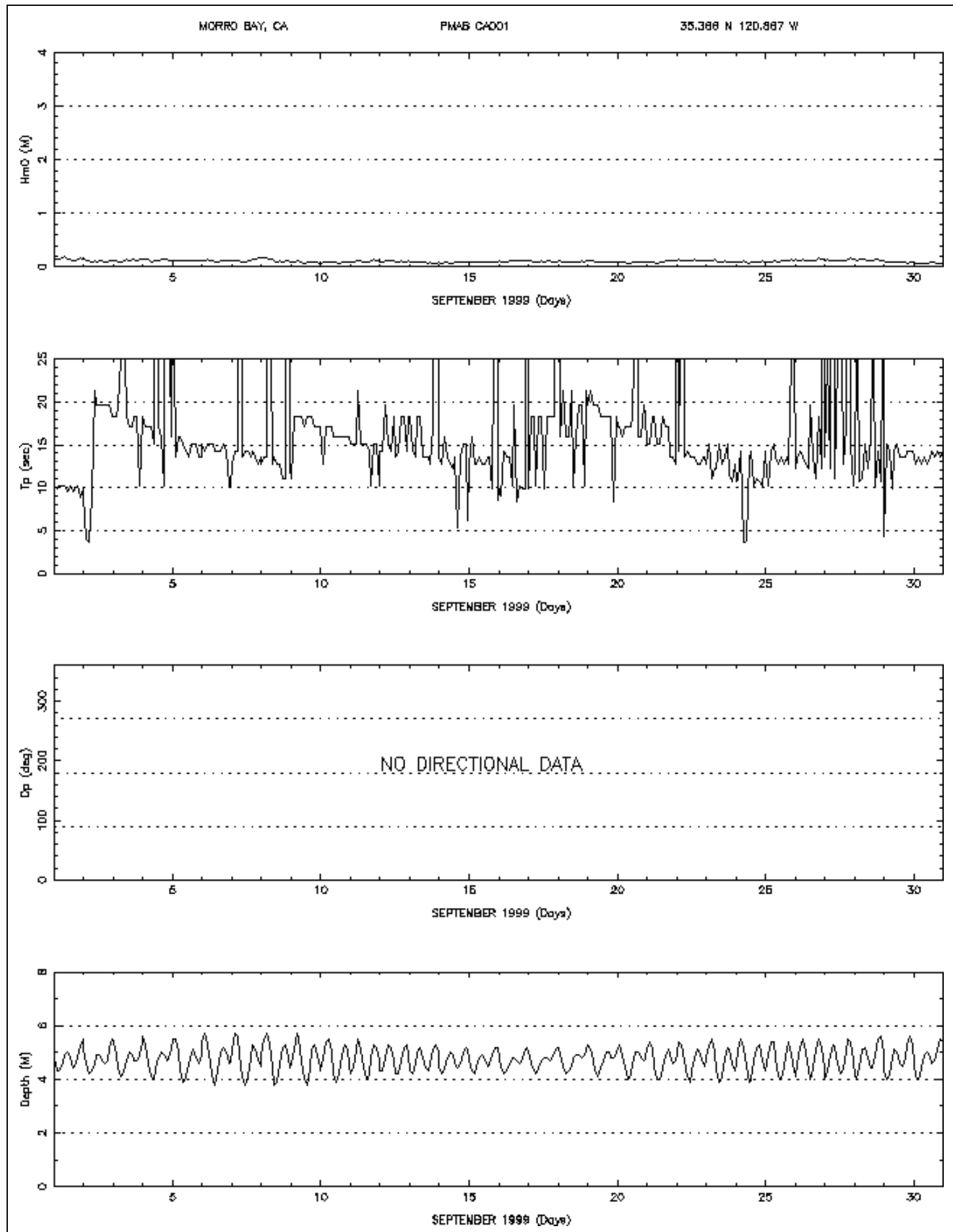

Figure 36. September 1999 monthly time series (CA001) 

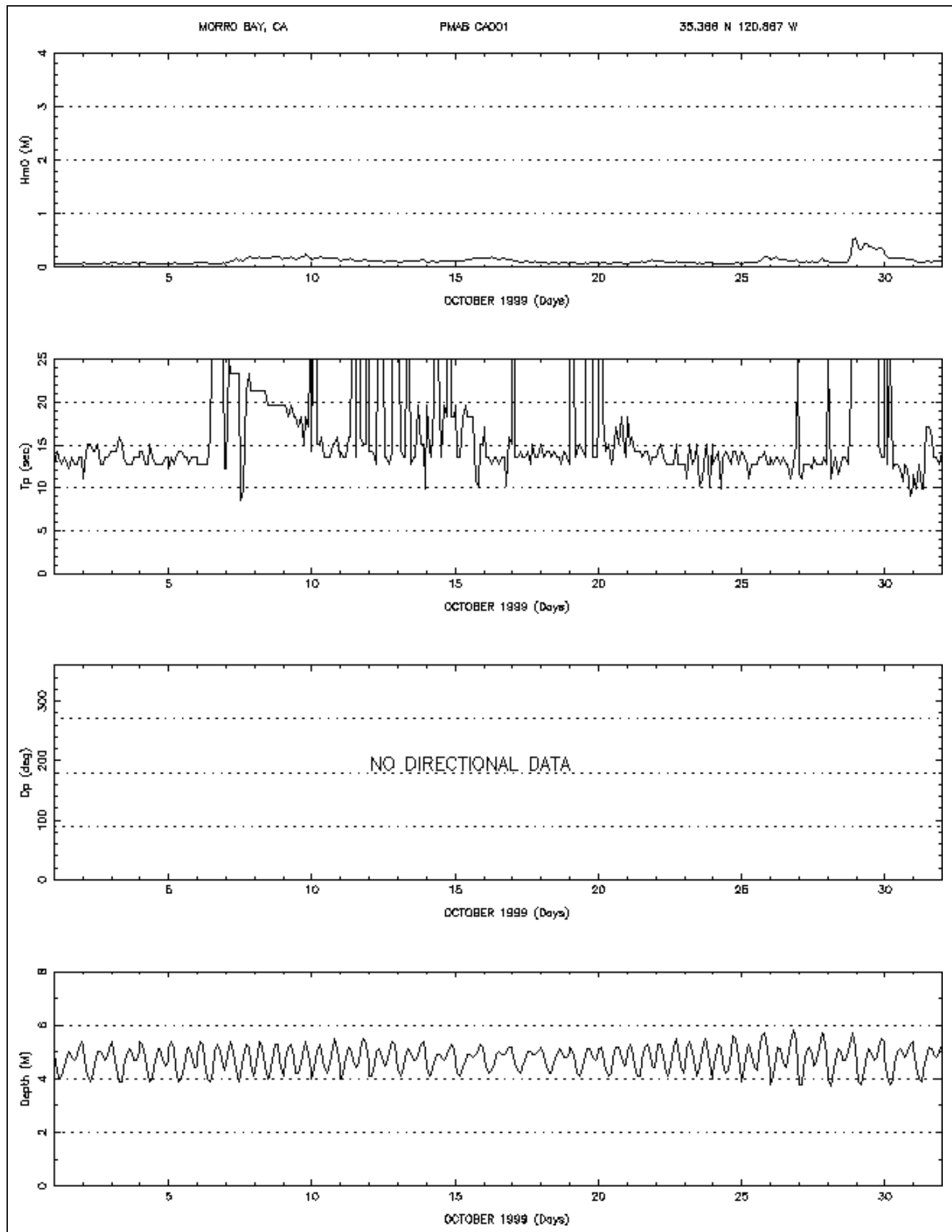

Figure 37. October 1999 monthly time series (CA001) 

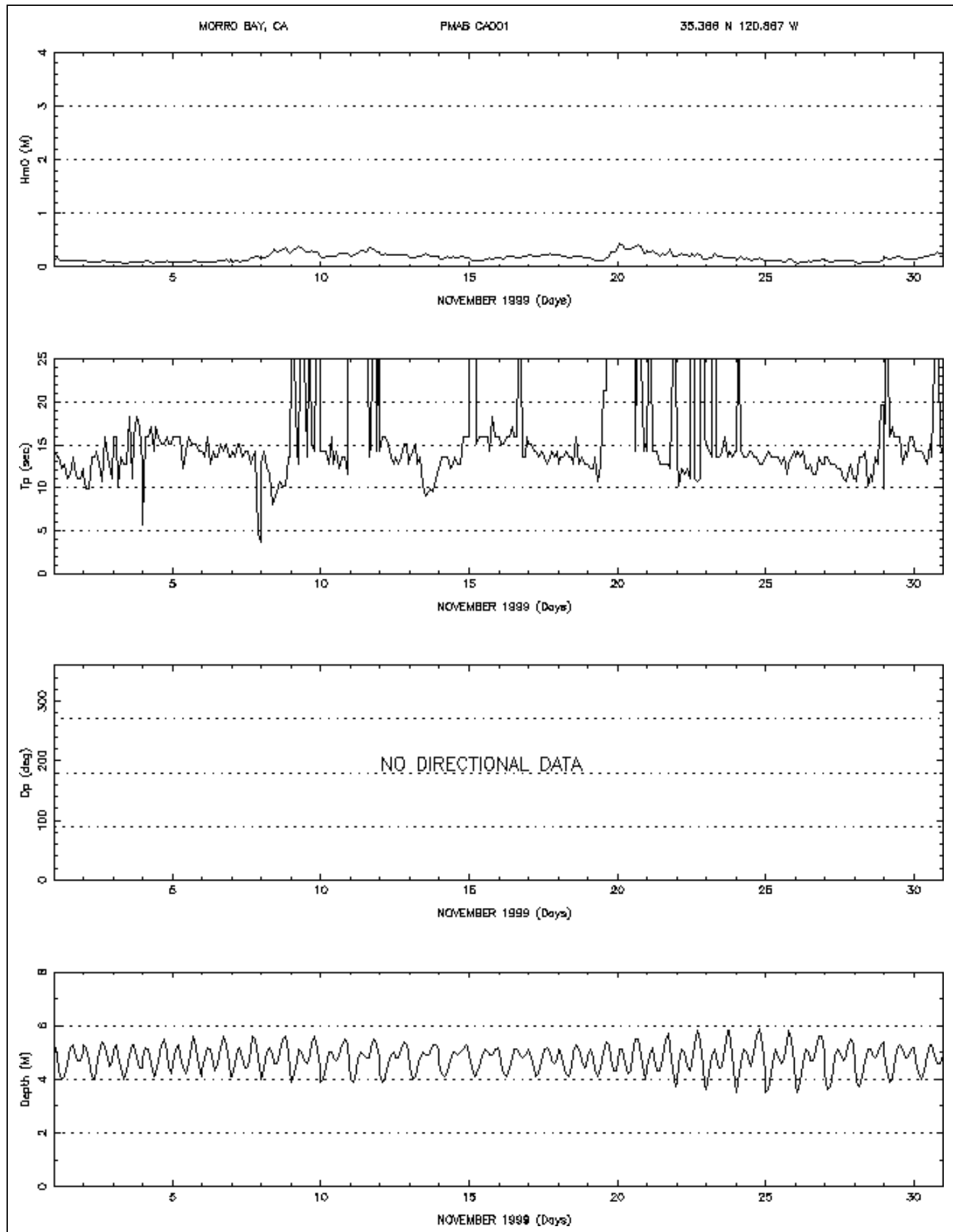

Figure 38. November 1999 monthly time series (CA001) 

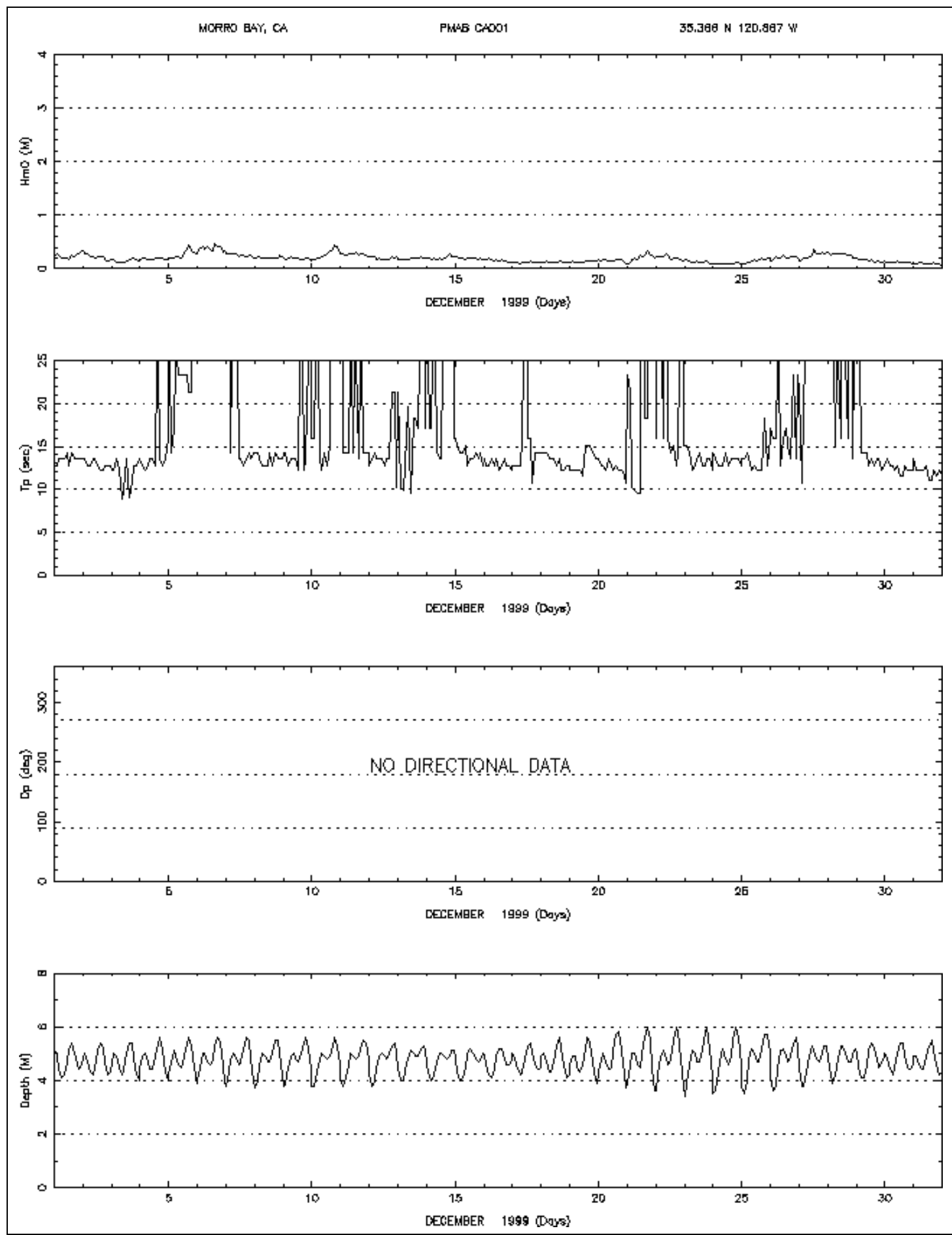

Figure 39. December 1999 monthly time series (CA001) 

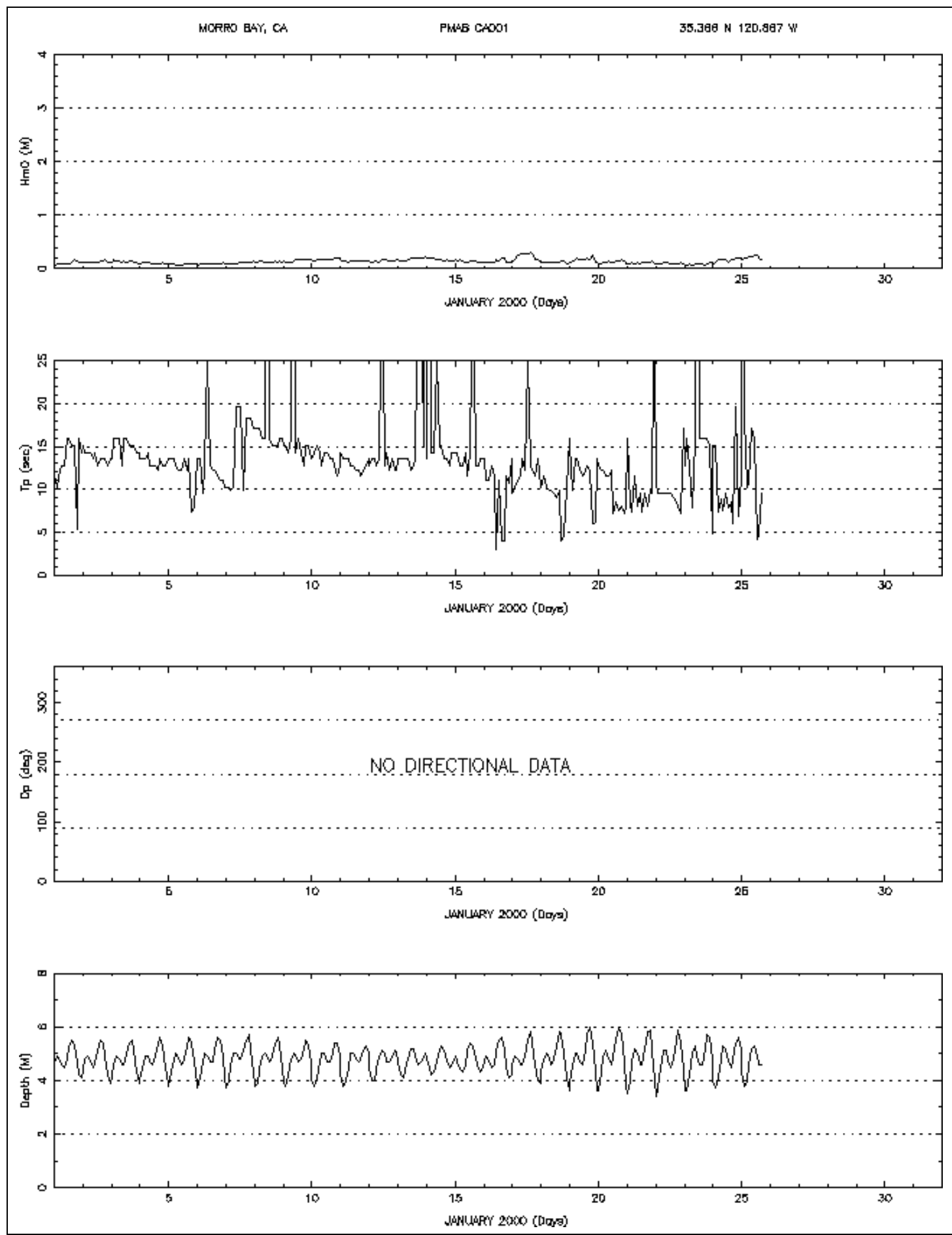

Figure 40. January 2000 monthly time series (CA001) 

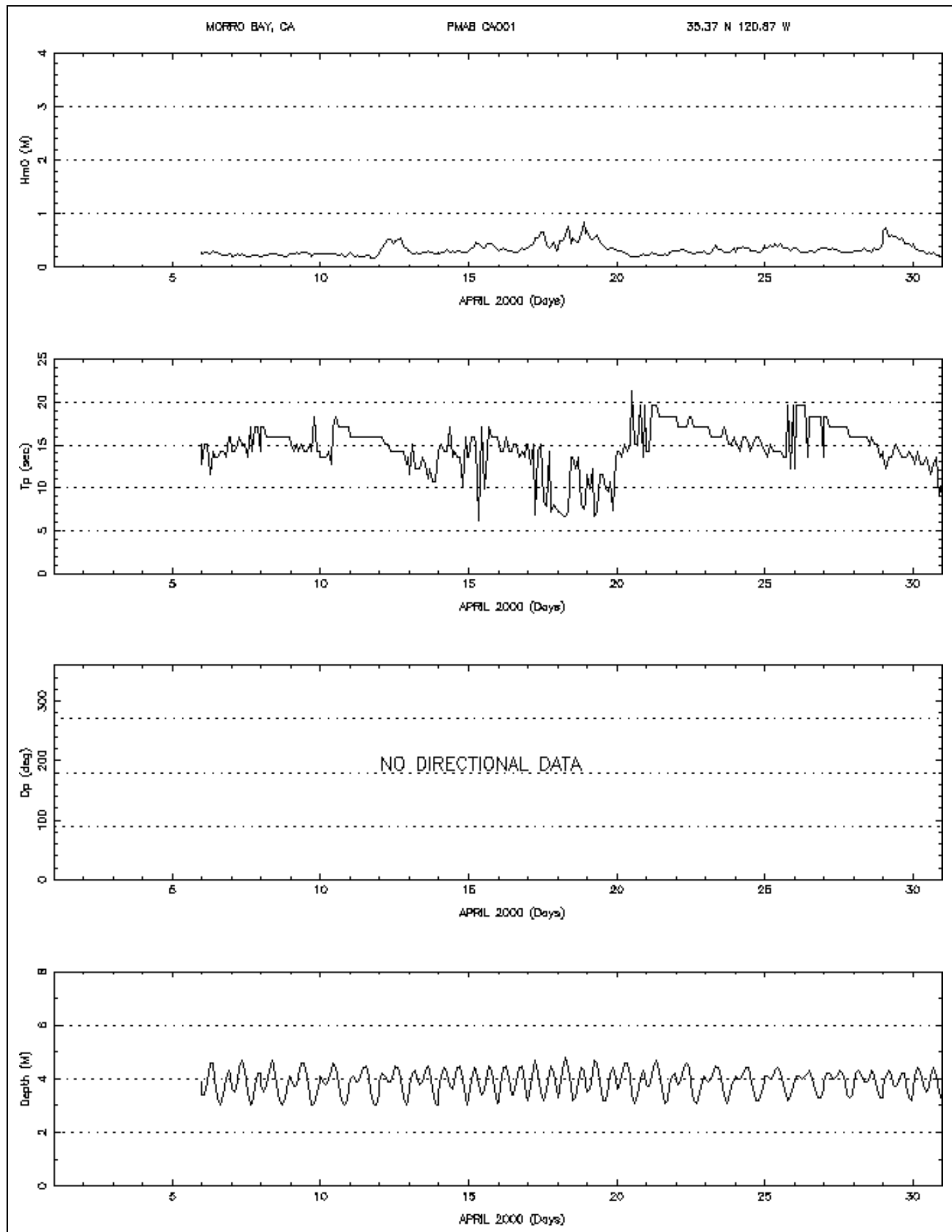

Figure 41. April 2000 monthly time series (CA001) 

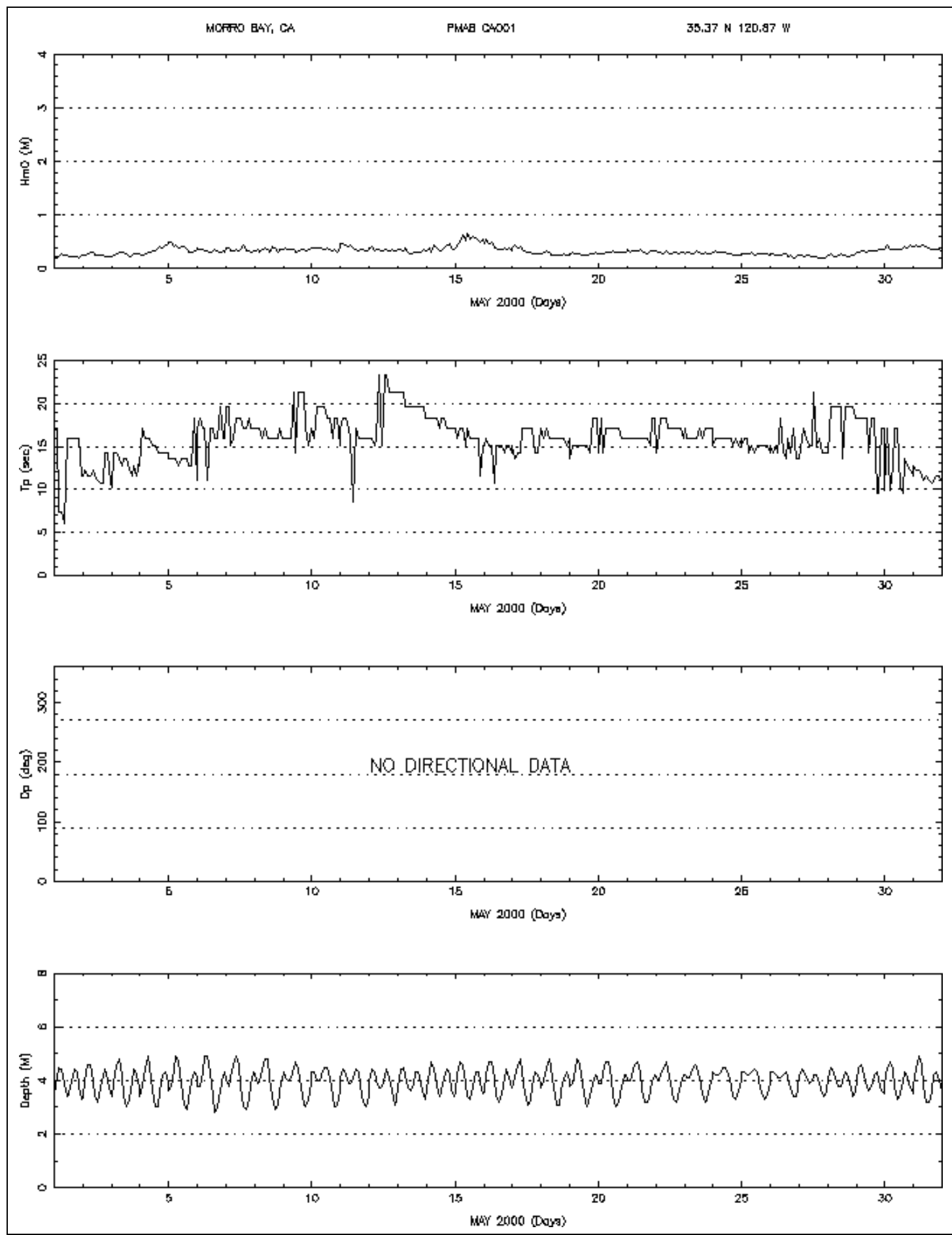

Figure 42. May 2000 monthly time series (CA001) 


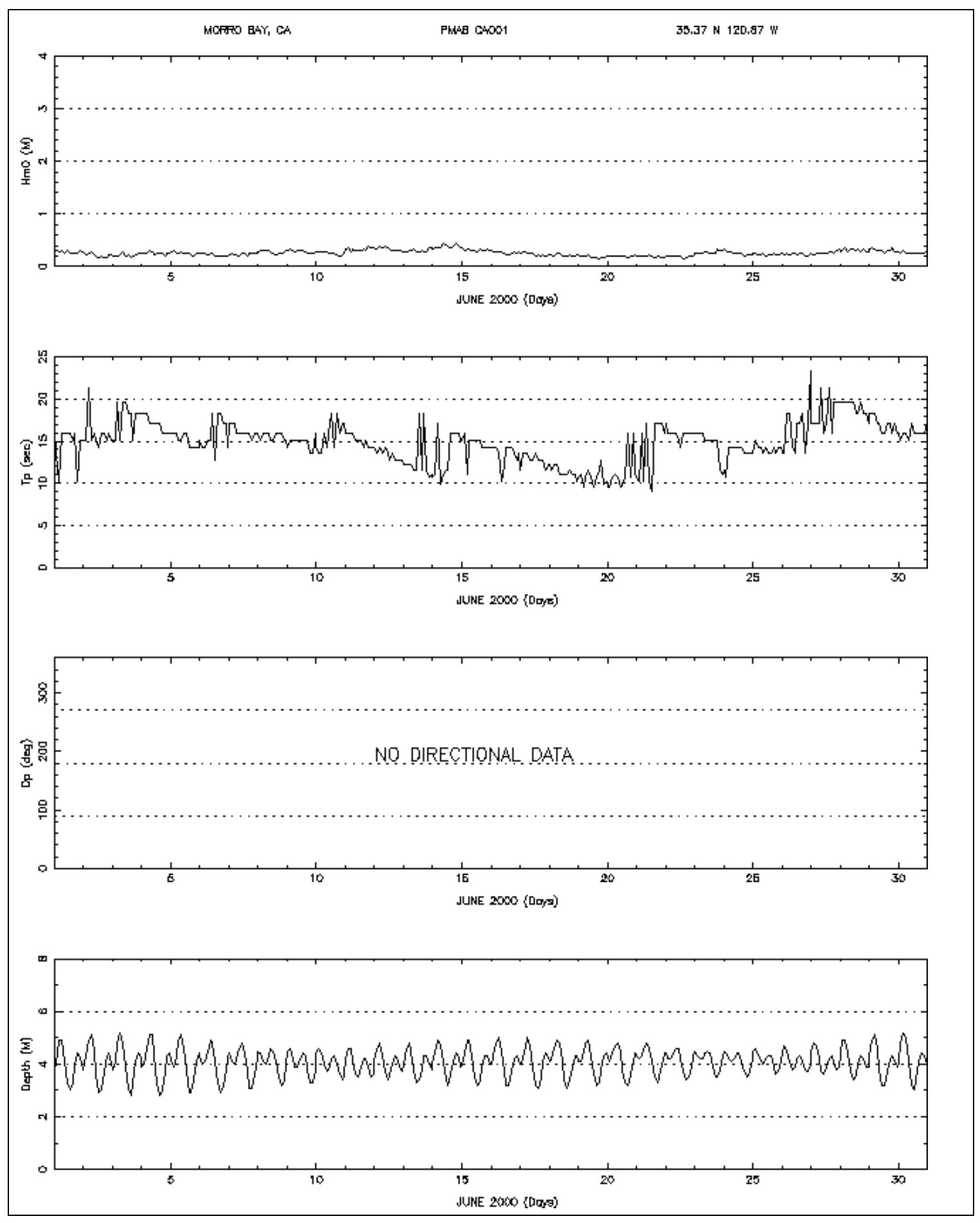

Figure 43. June 2000 monthly time series (CA001) 

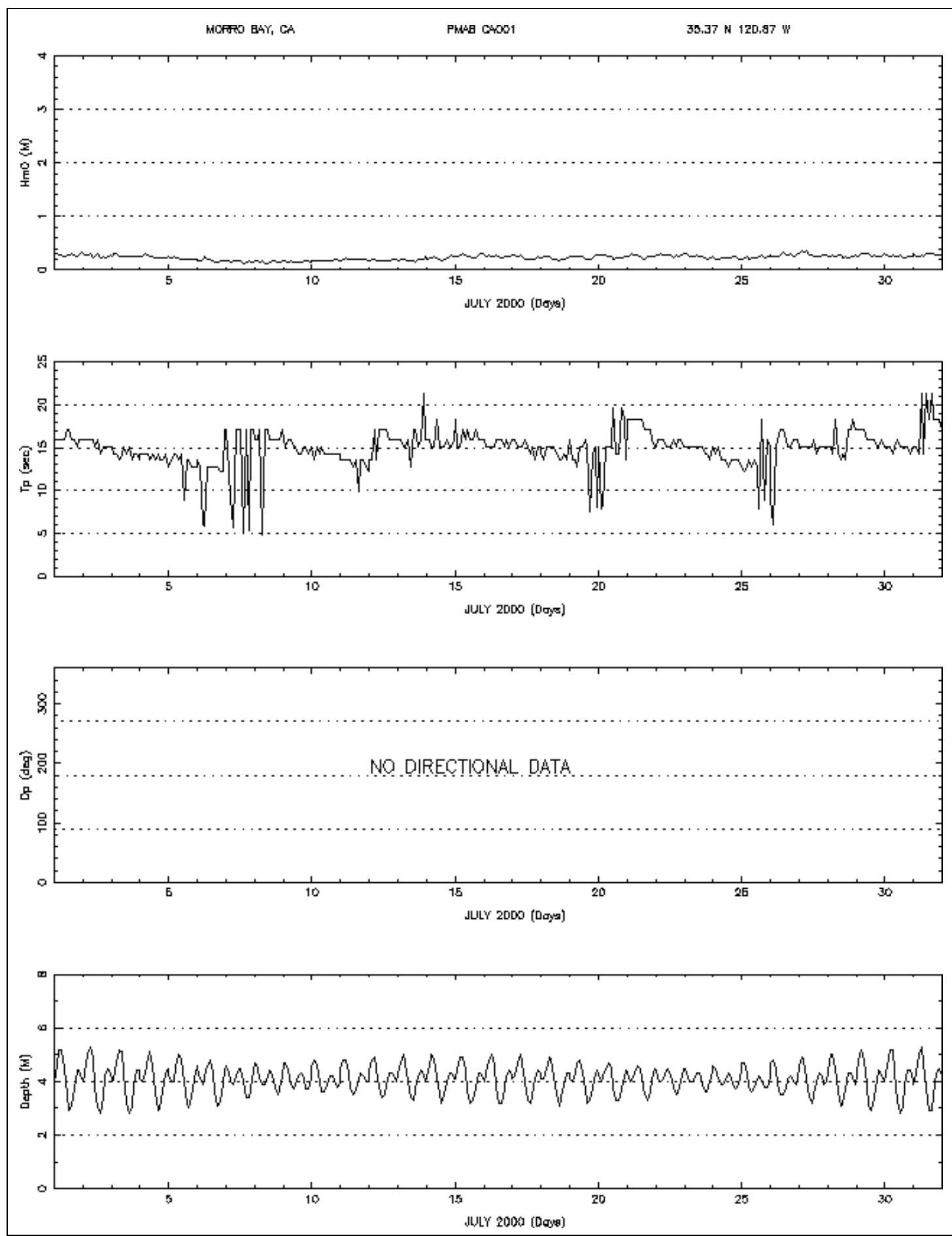

Figure 44. July 2000 monthly time series (CA001) 

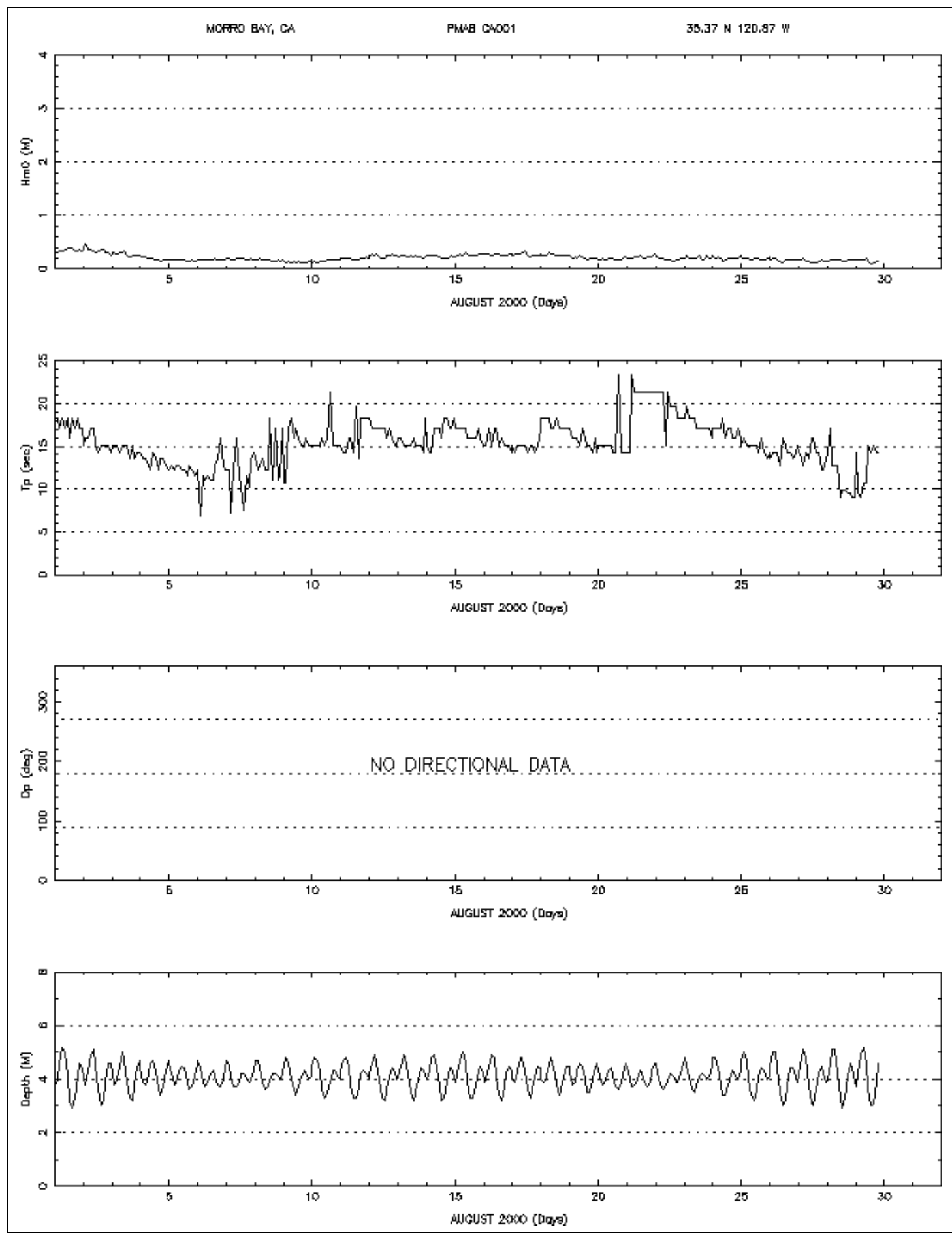

Figure 45. August 2000 monthly time series (CA001) 


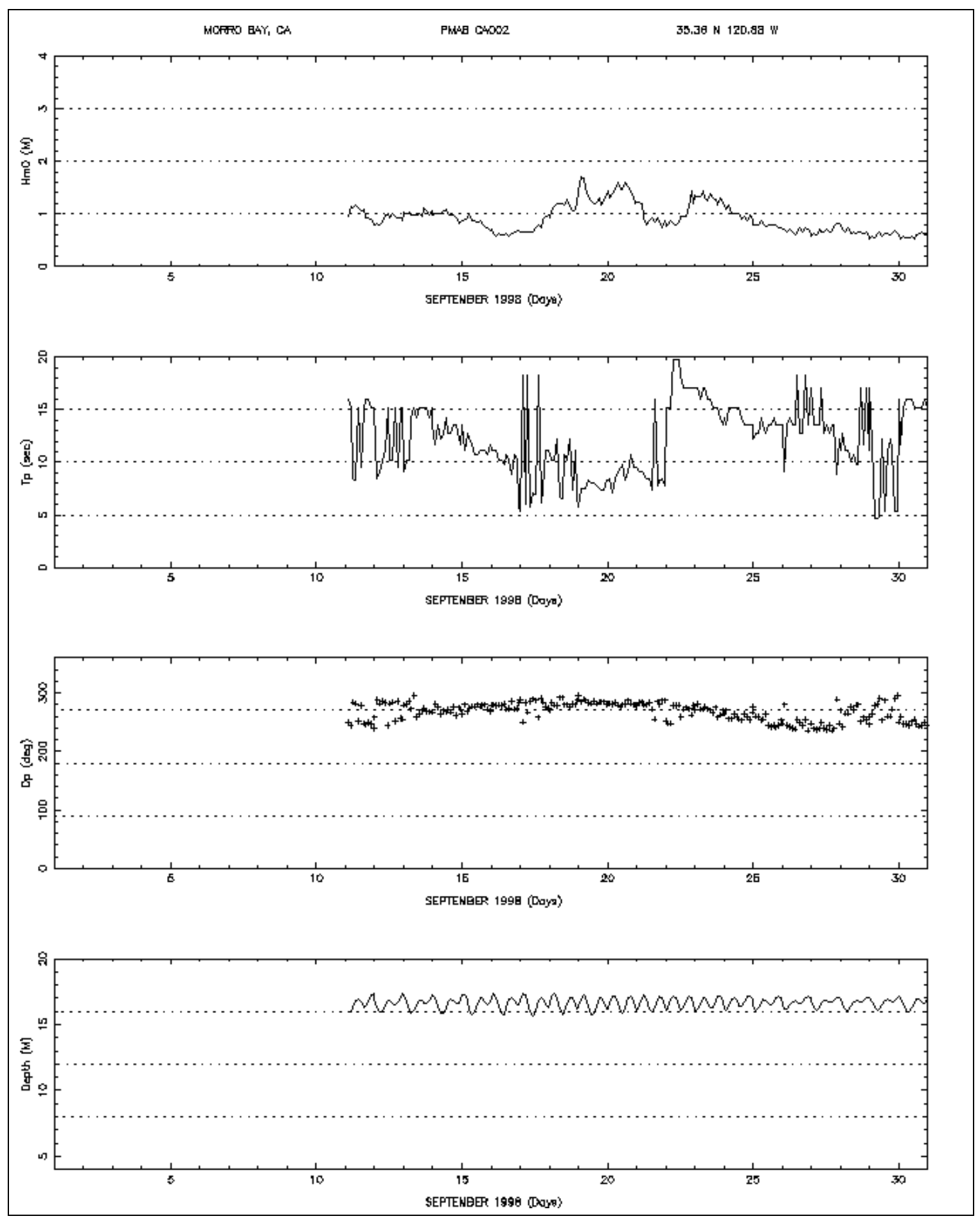

Figure 46. September 1998 monthly time series (CA002) 


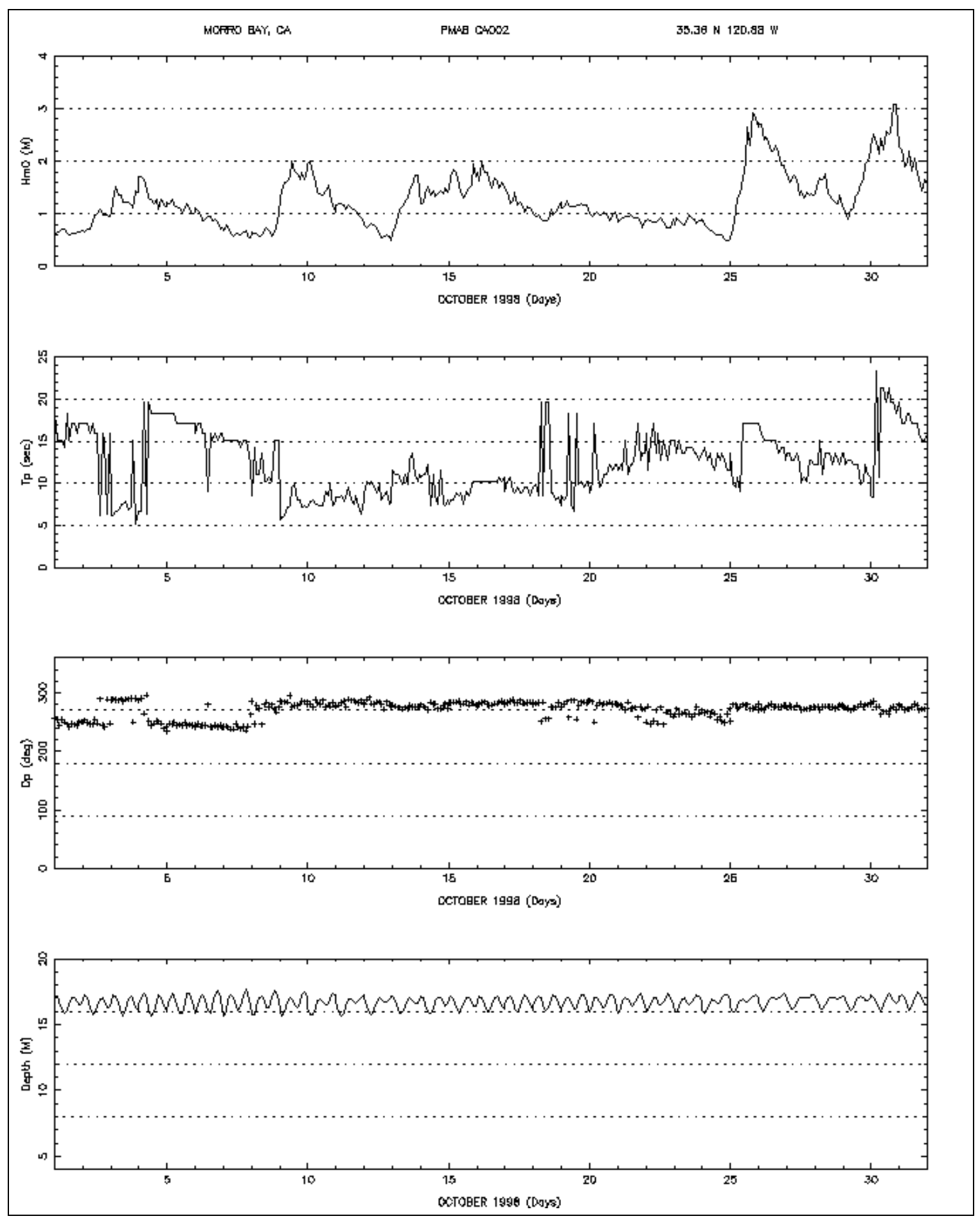

Figure 47. October 1998 monthly time series (CA002) 

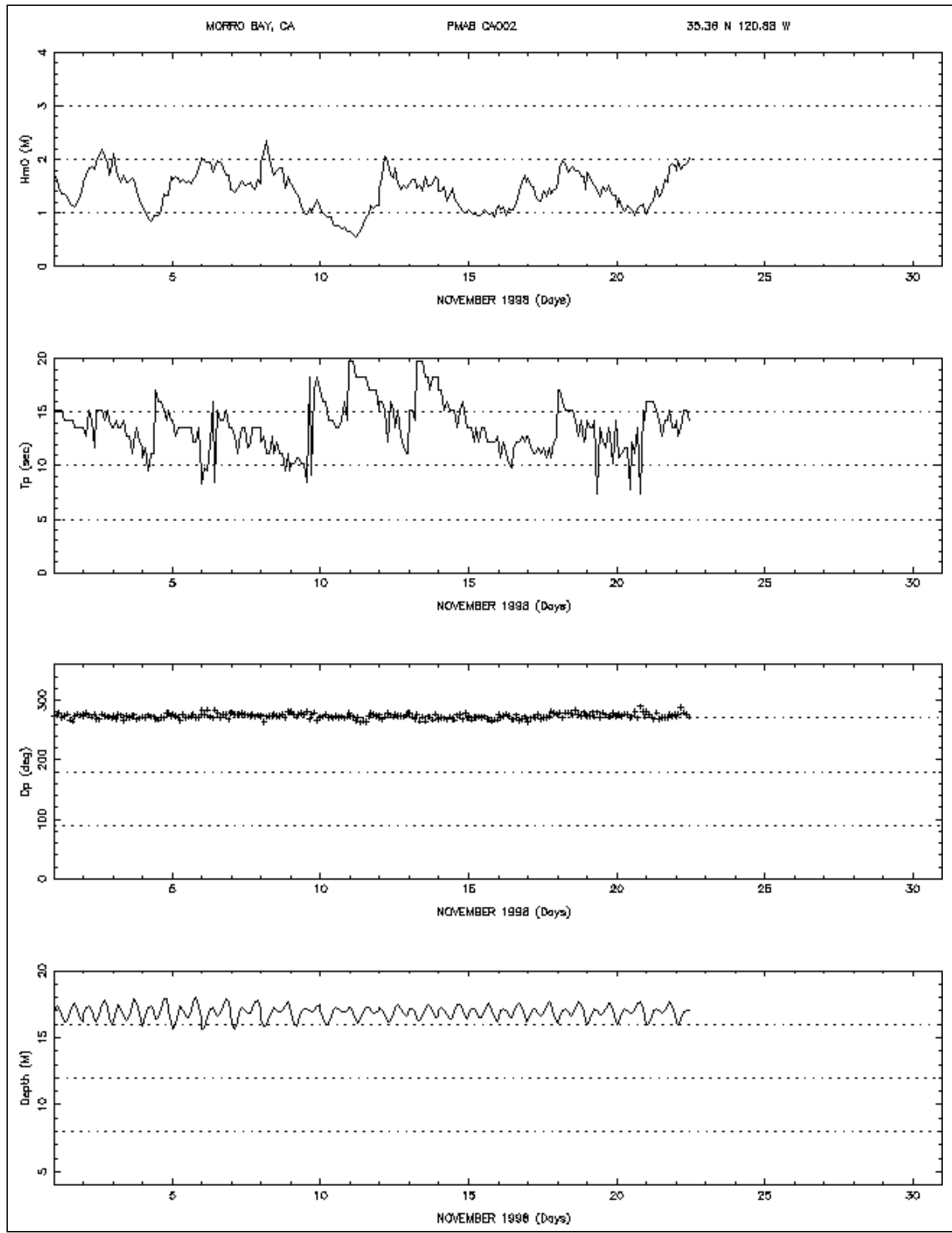

Figure 48. November 1998 monthly time series (CA002) 


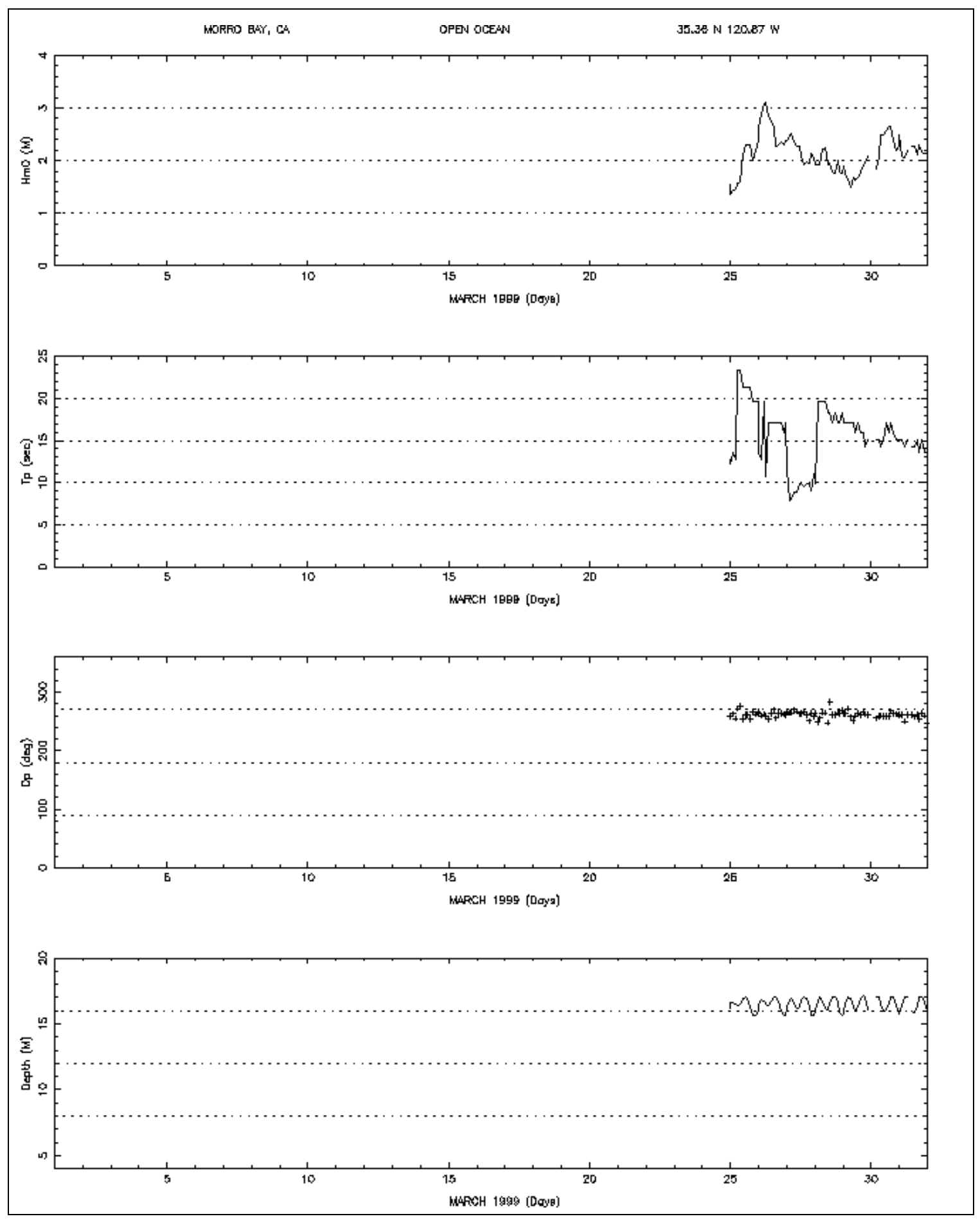

Figure 49. March 1999 monthly time series (CA002) 


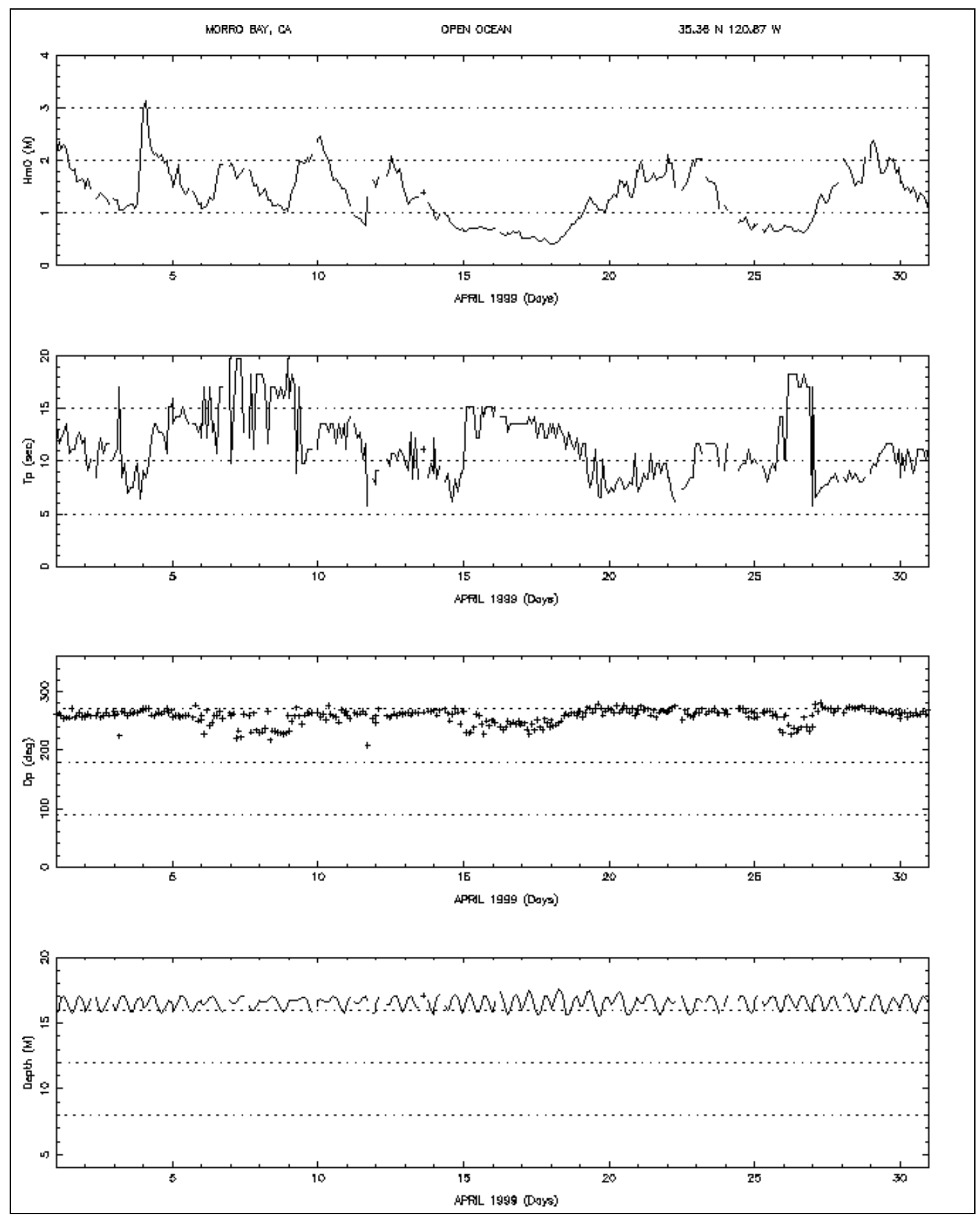

Figure 50. April 1999 monthly time series (CA002) 

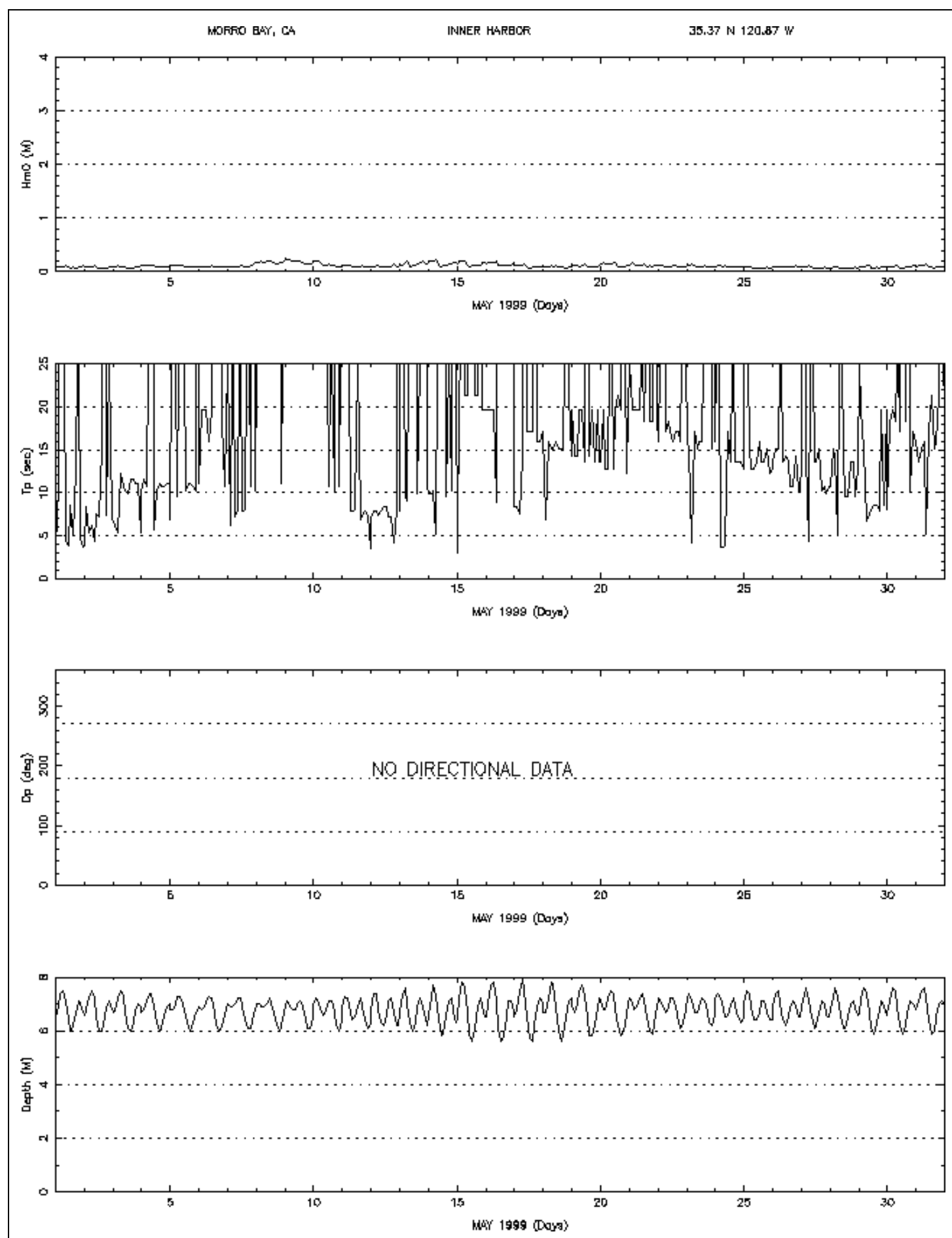

Figure 51. May 1999 monthly time series (CA002) 


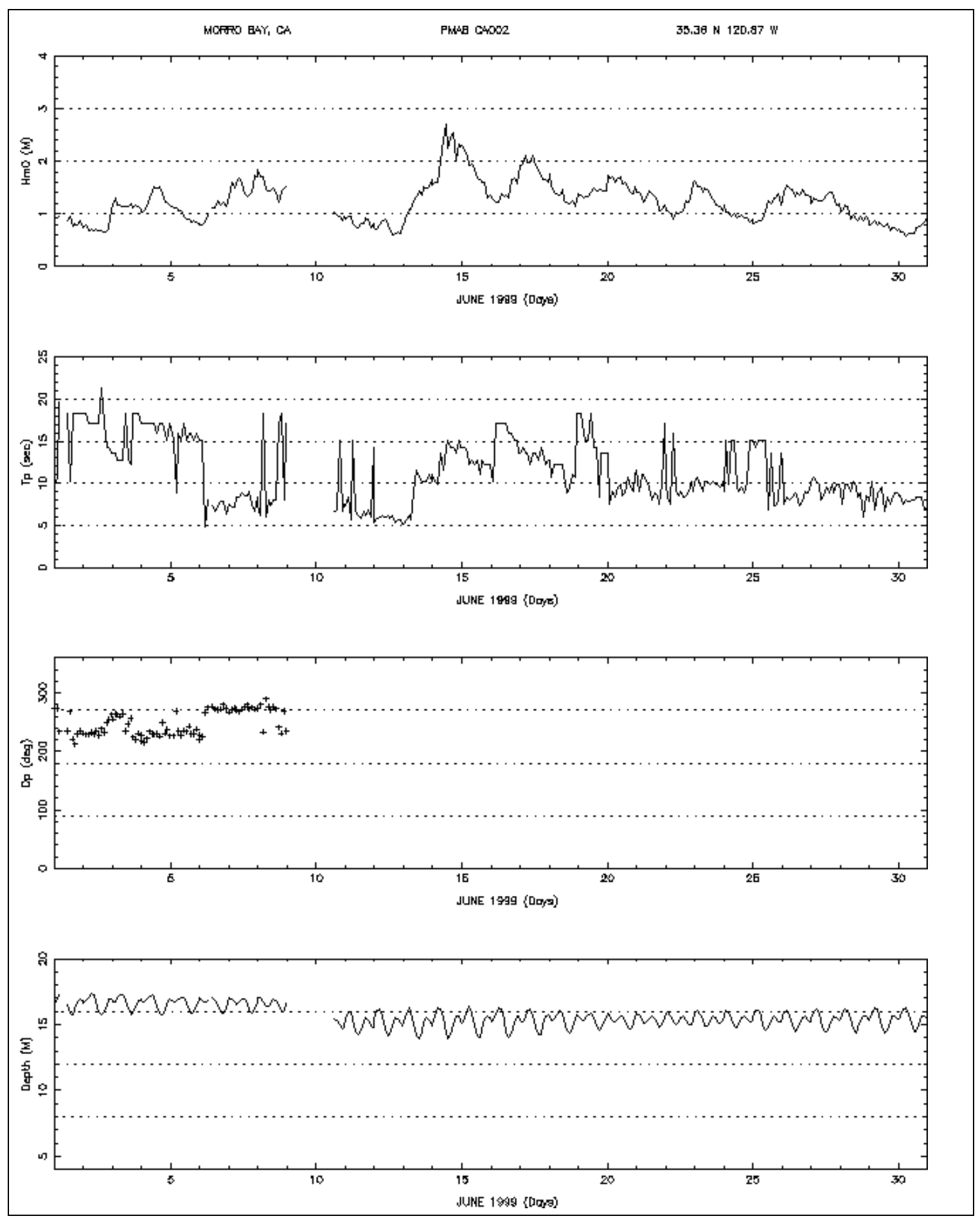

Figure 52. June 1999 monthly time series (CA002) 

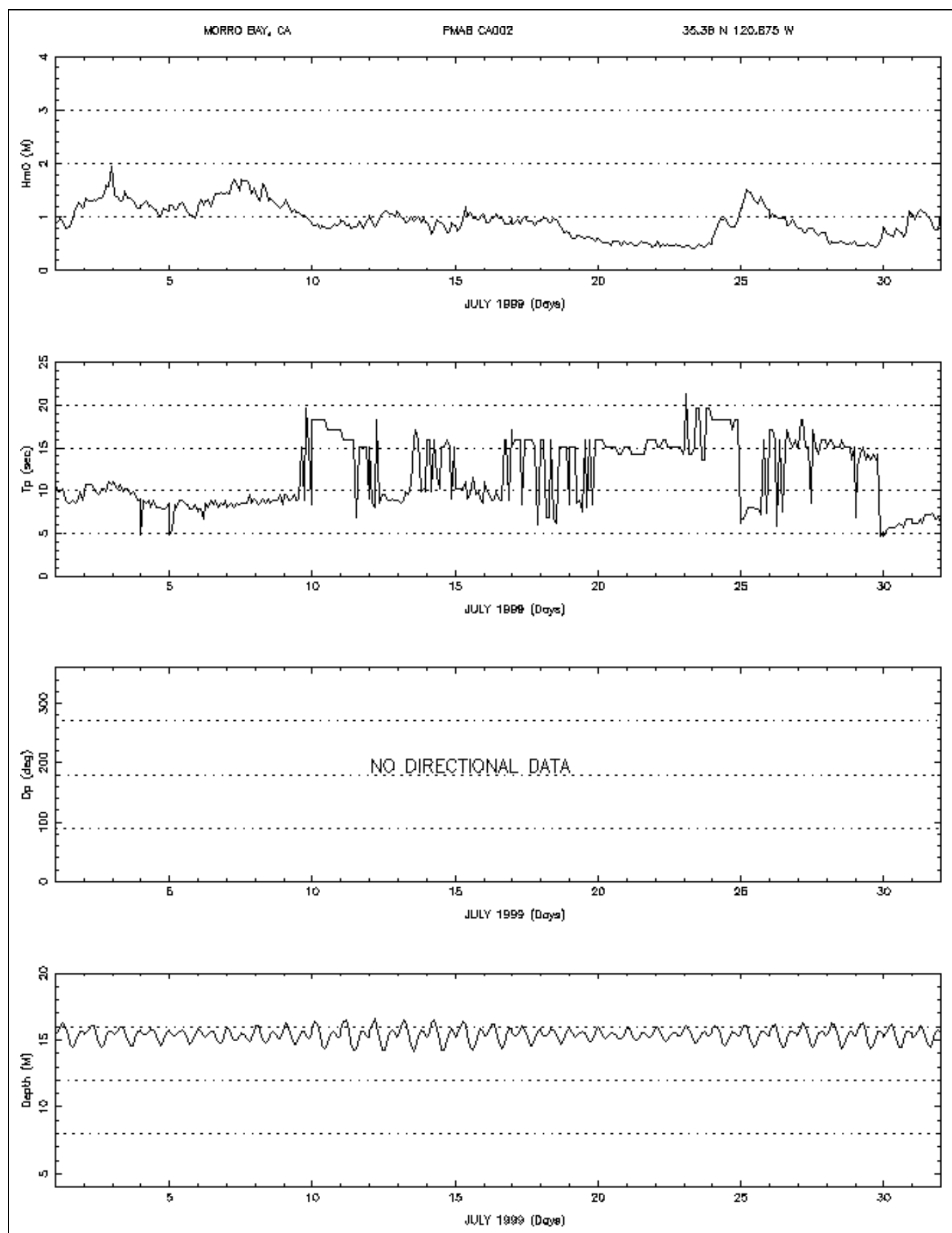

Figure 53. July 1999 monthly time series (CA002) 

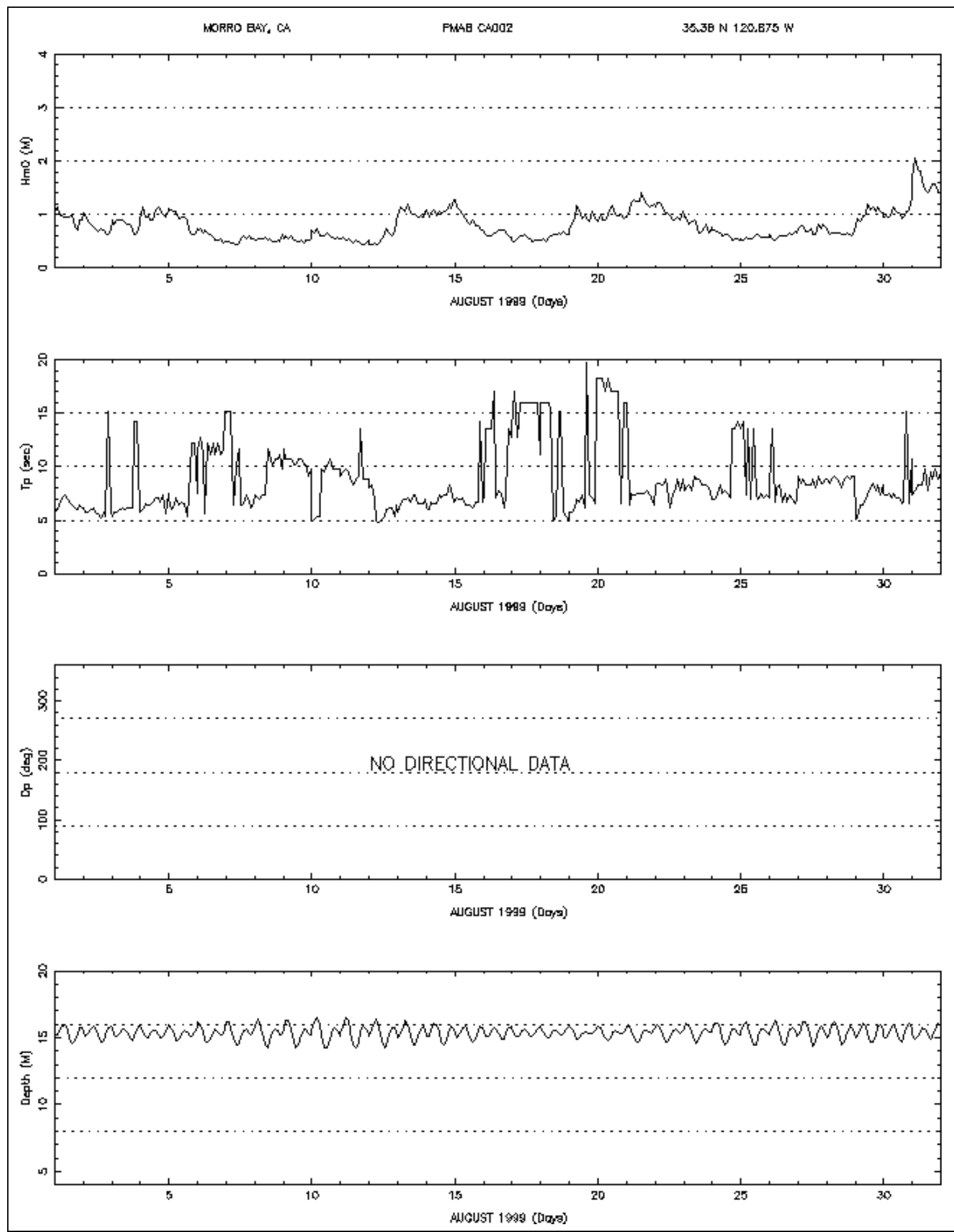

Figure 54. August 1999 monthly time series (CA002) 

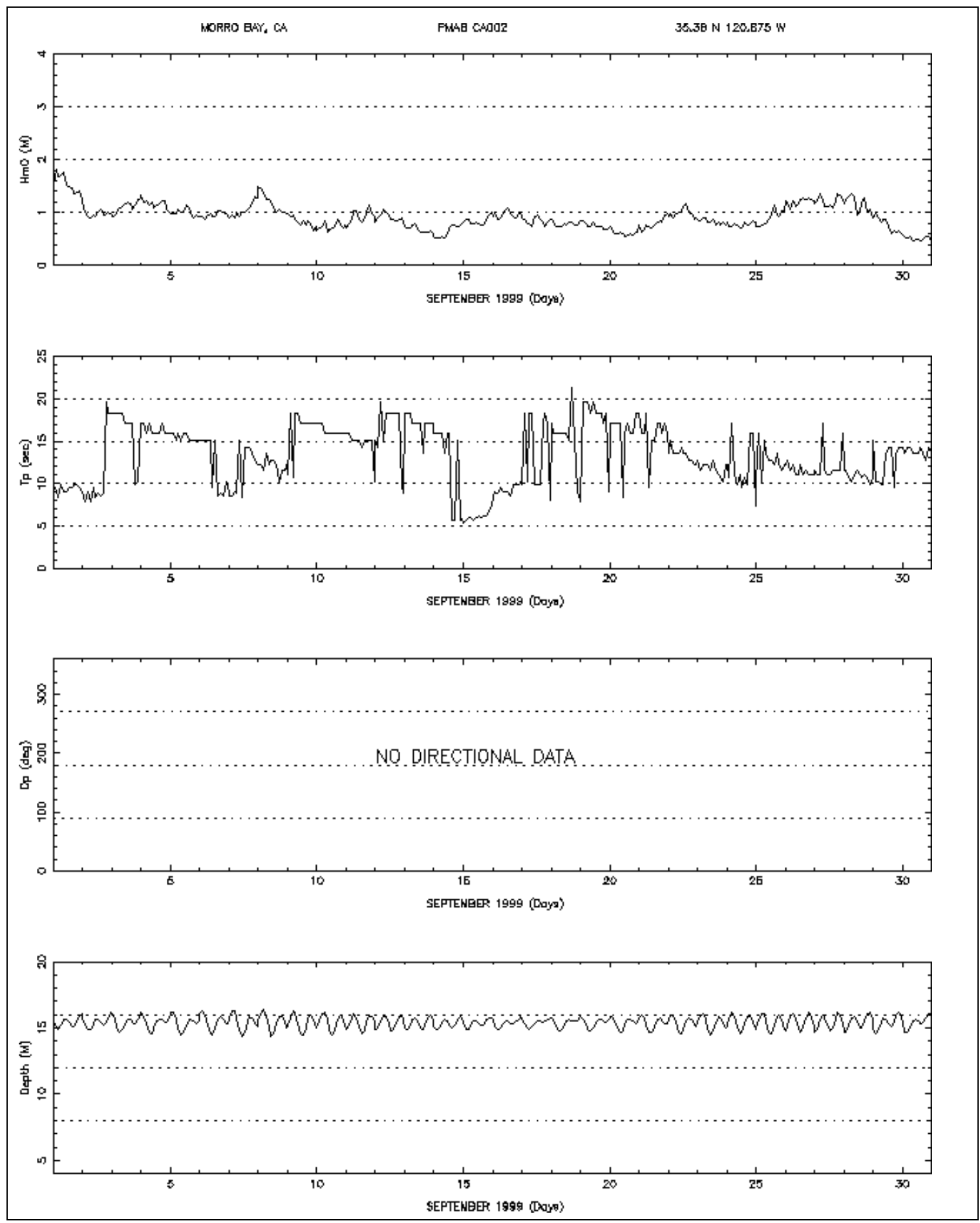

Figure 55. September 1999 monthly time series (CA002) 

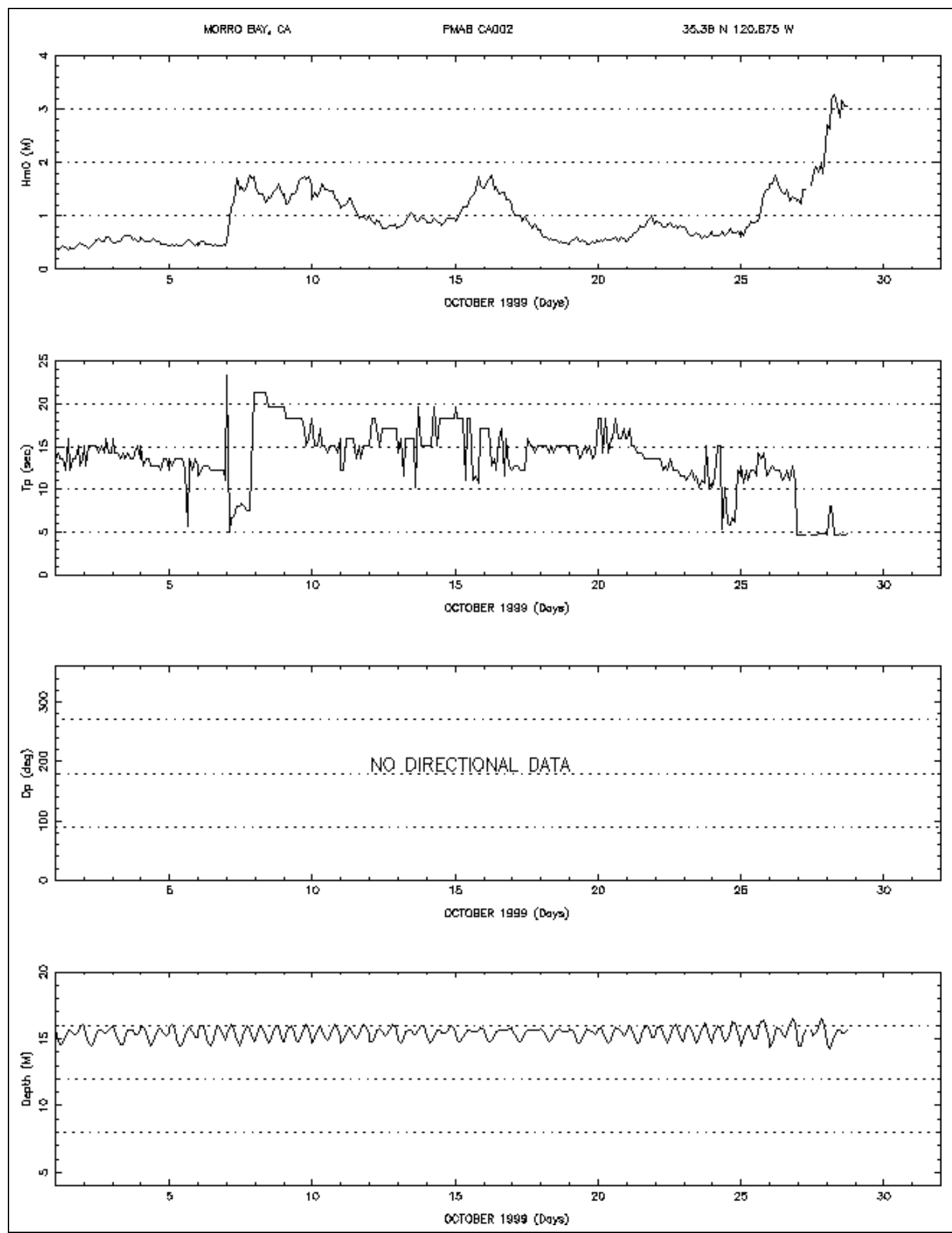

Figure 56. October 1999 monthly time series (CA002) 

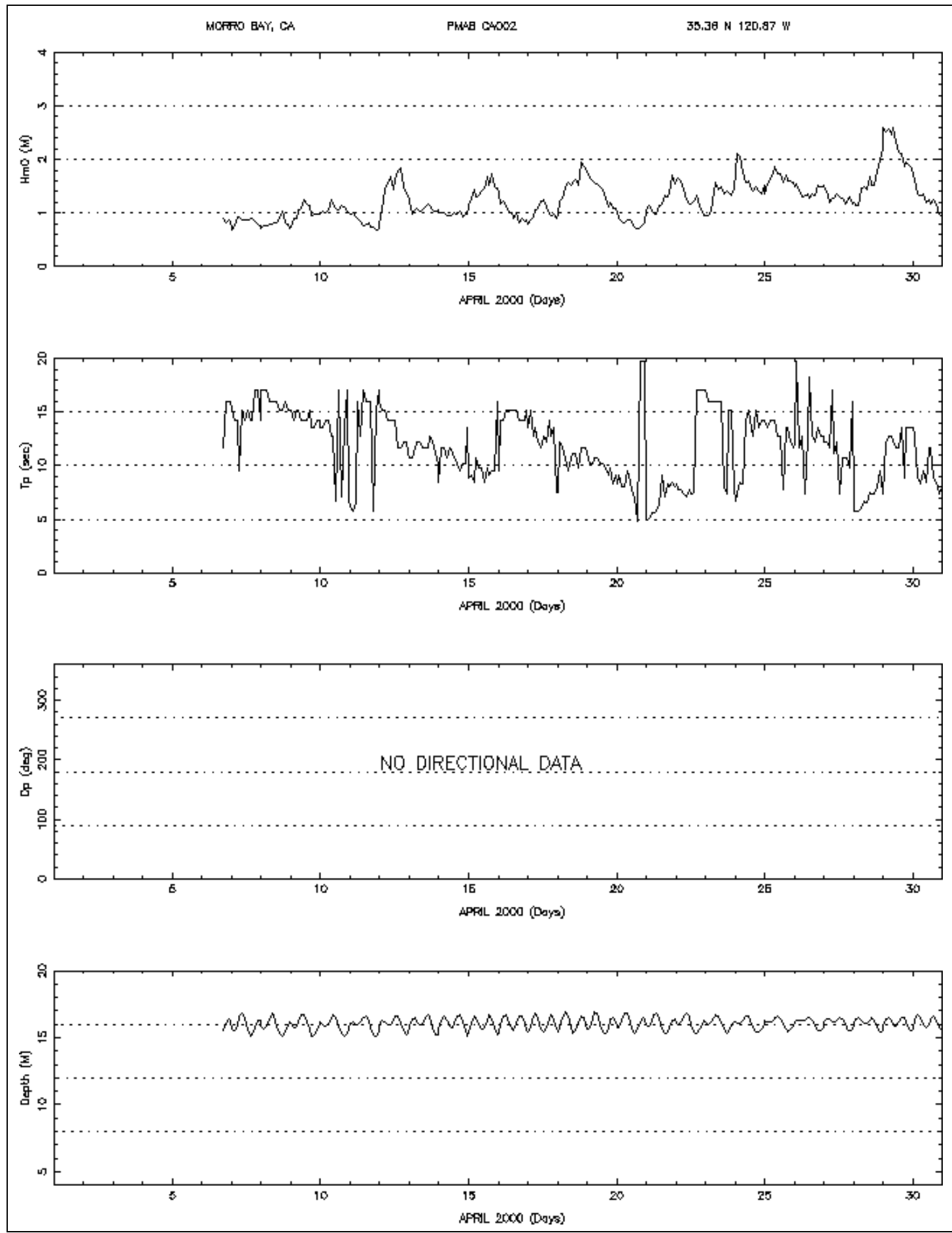

Figure 57. April 2000 monthly time series (CA002) 

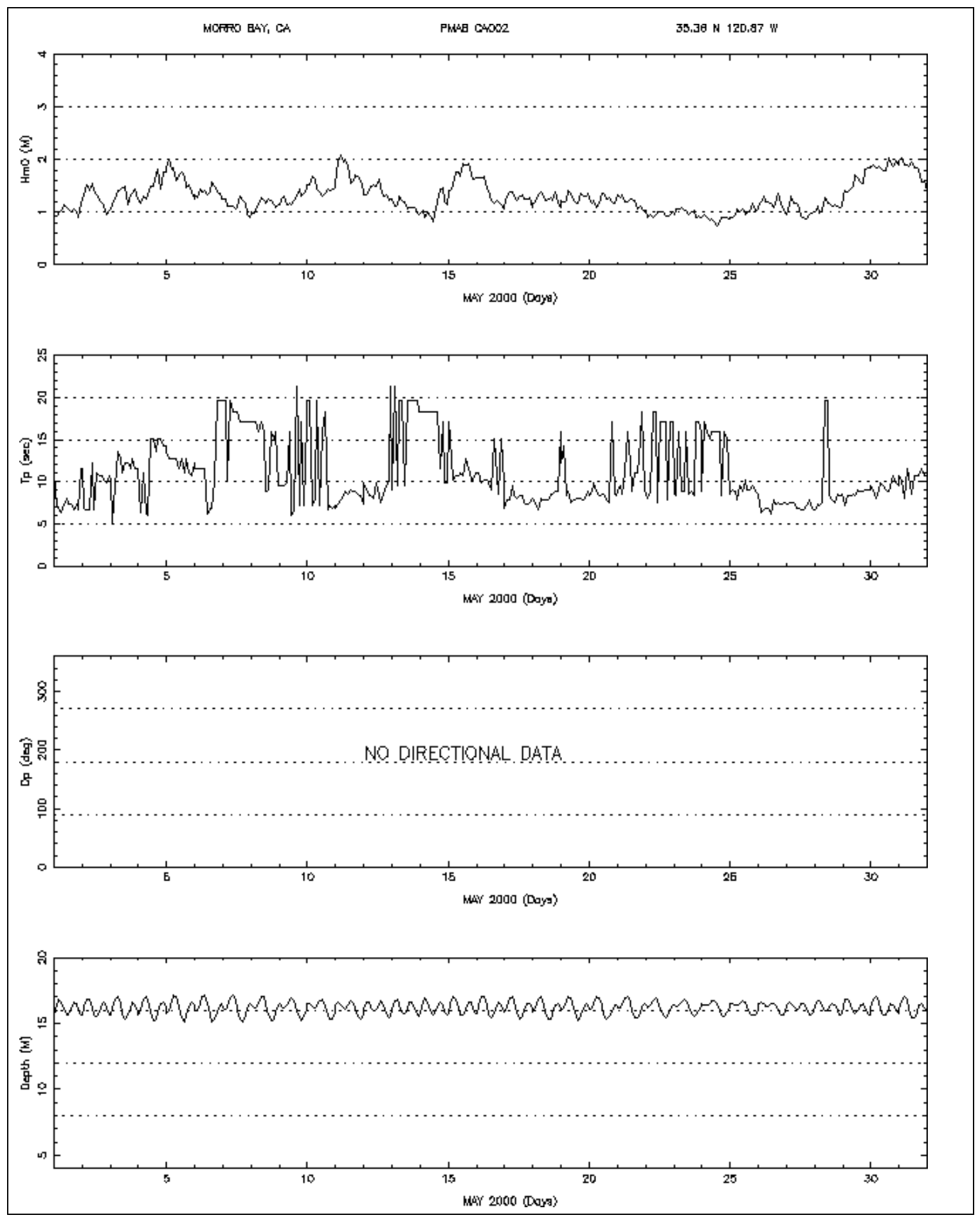

Figure 58. May 2000 monthly time series (CA002) 

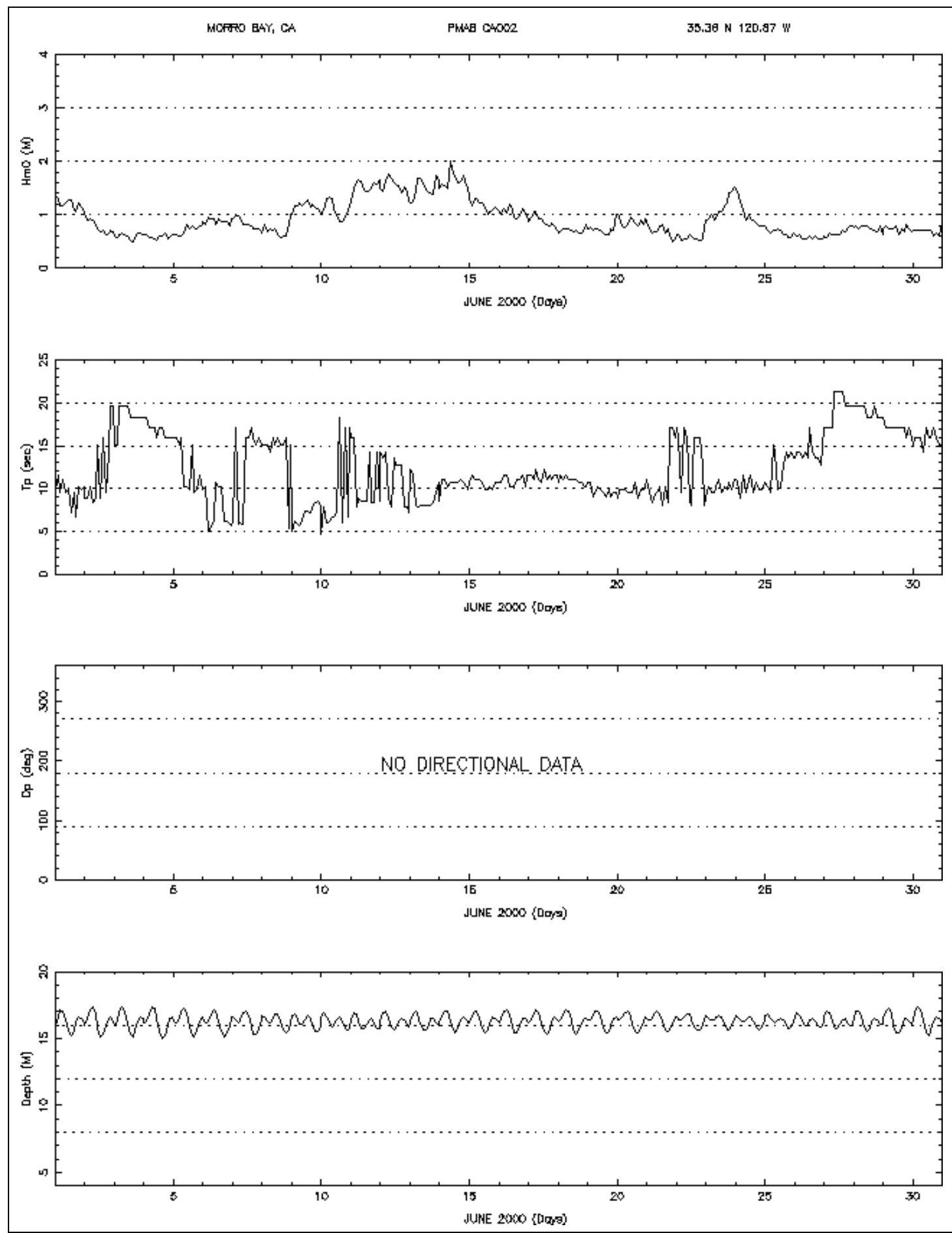

Figure 59. June 2000 monthly time series (CA002) 

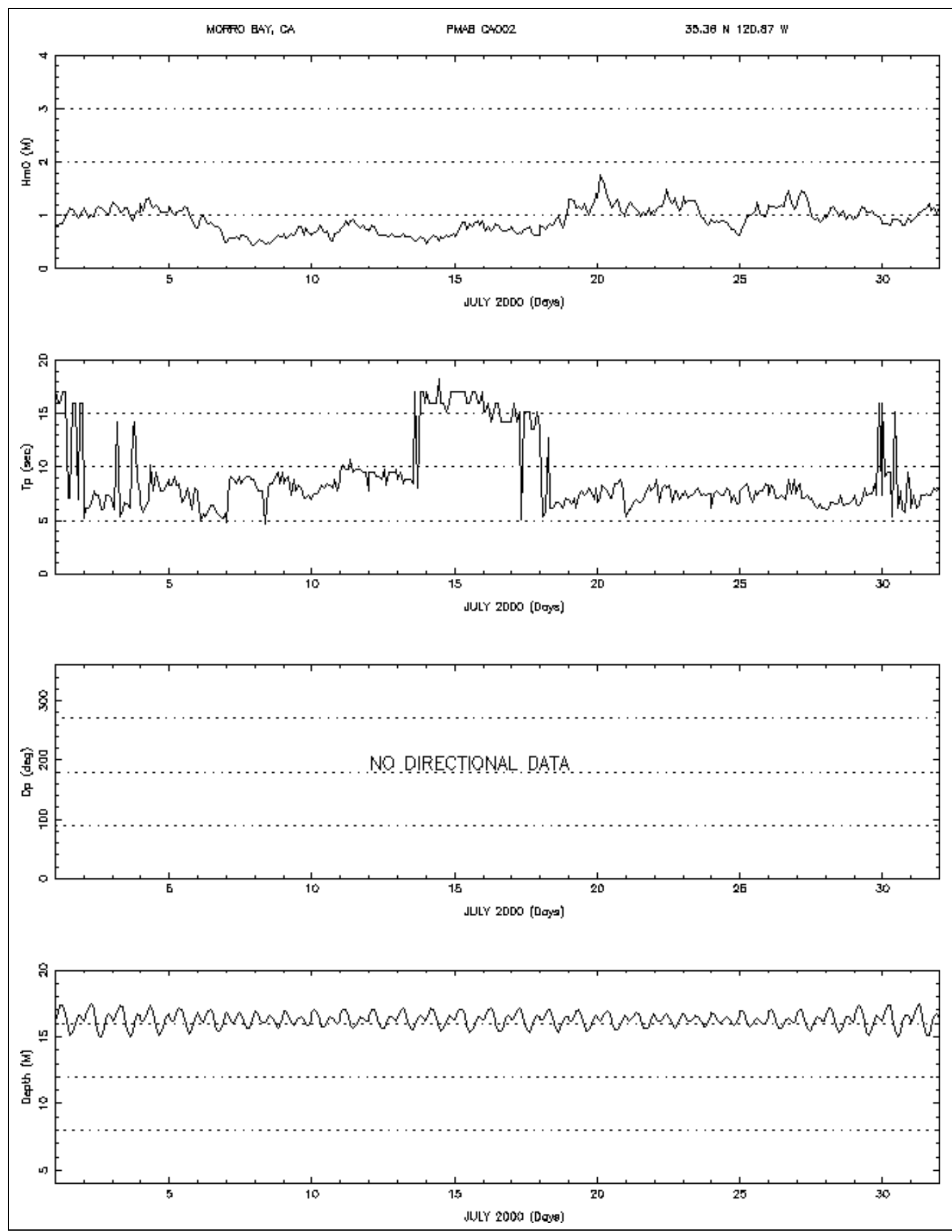

Figure 60 . July 2000 monthly time series (CA002) 

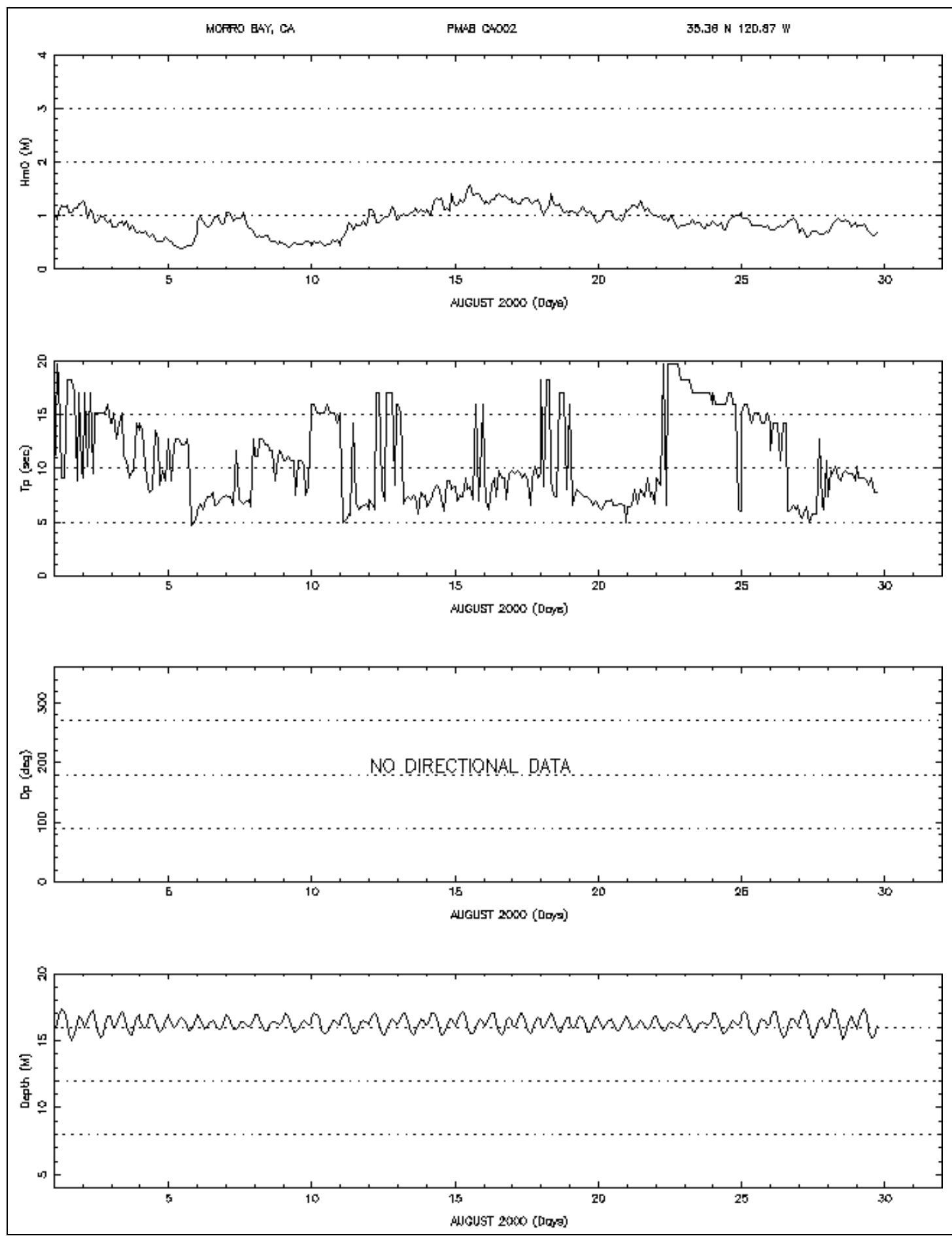

Figure 61. August 2000 monthly time series (CA002) 


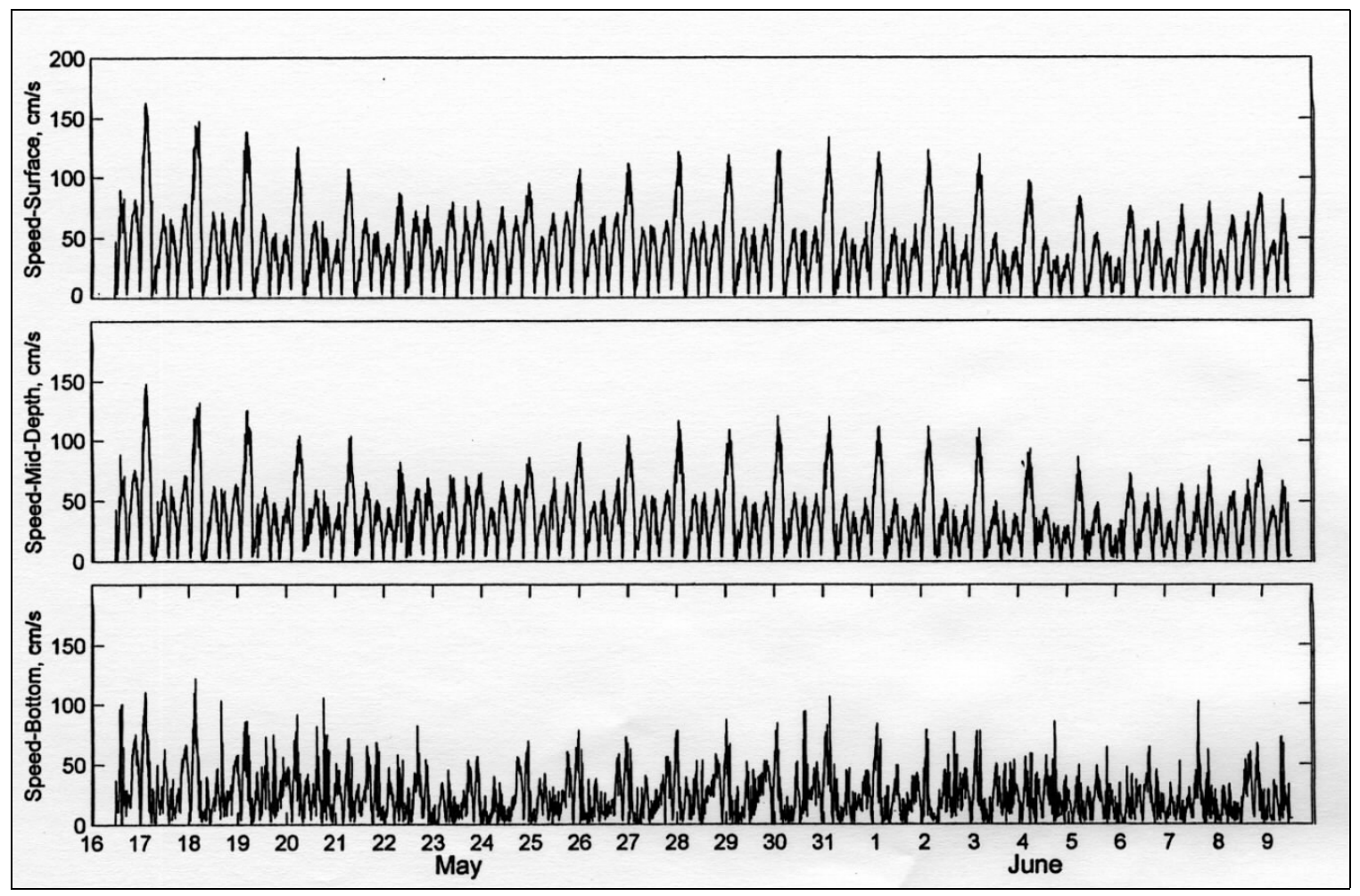

Figure 62. Morro Bay near-bottom, near-middepth, and near-surface current speeds

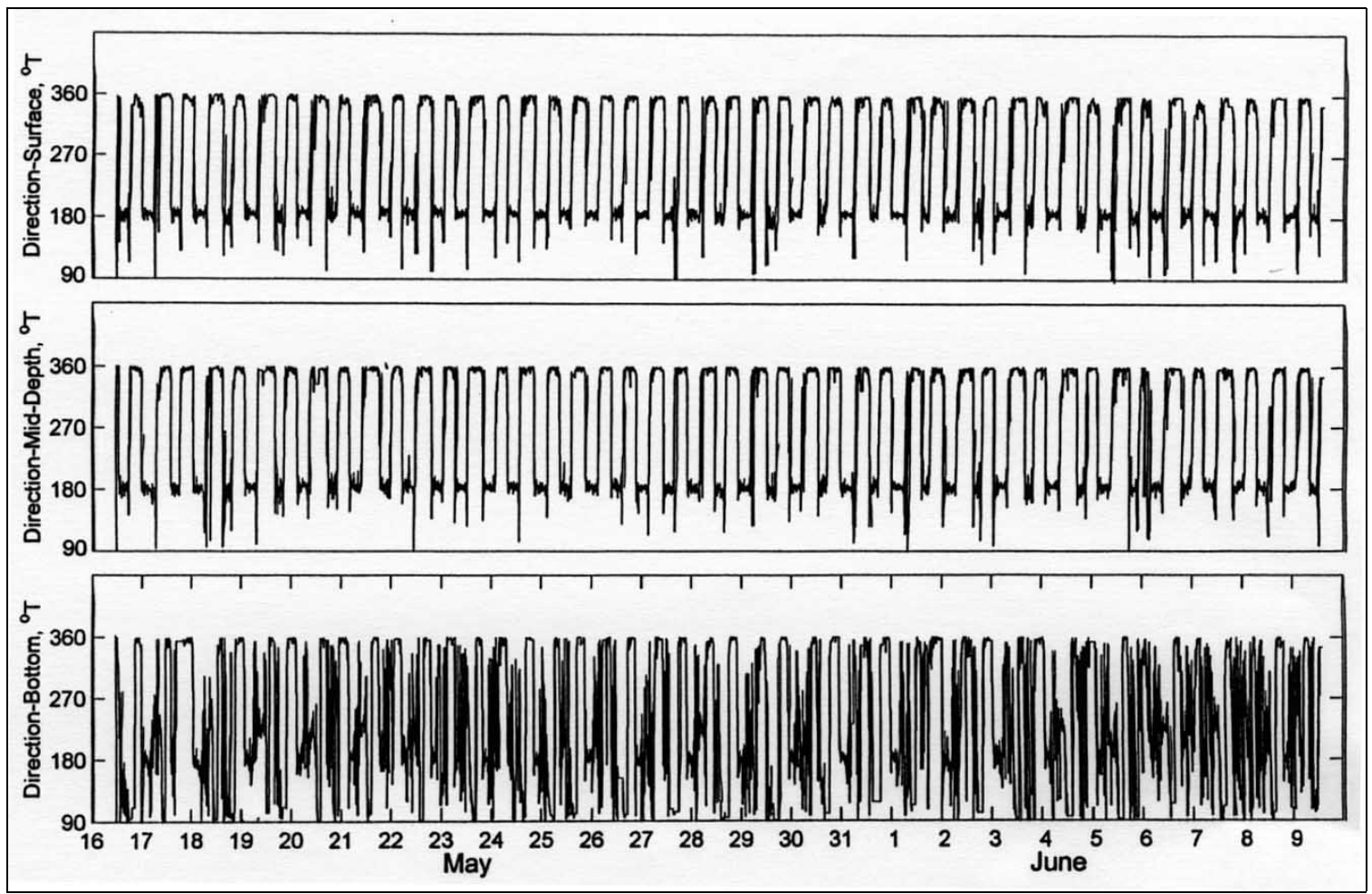

Figure 63. Morro Bay near-bottom, near-middepth, and near-surface current directions 

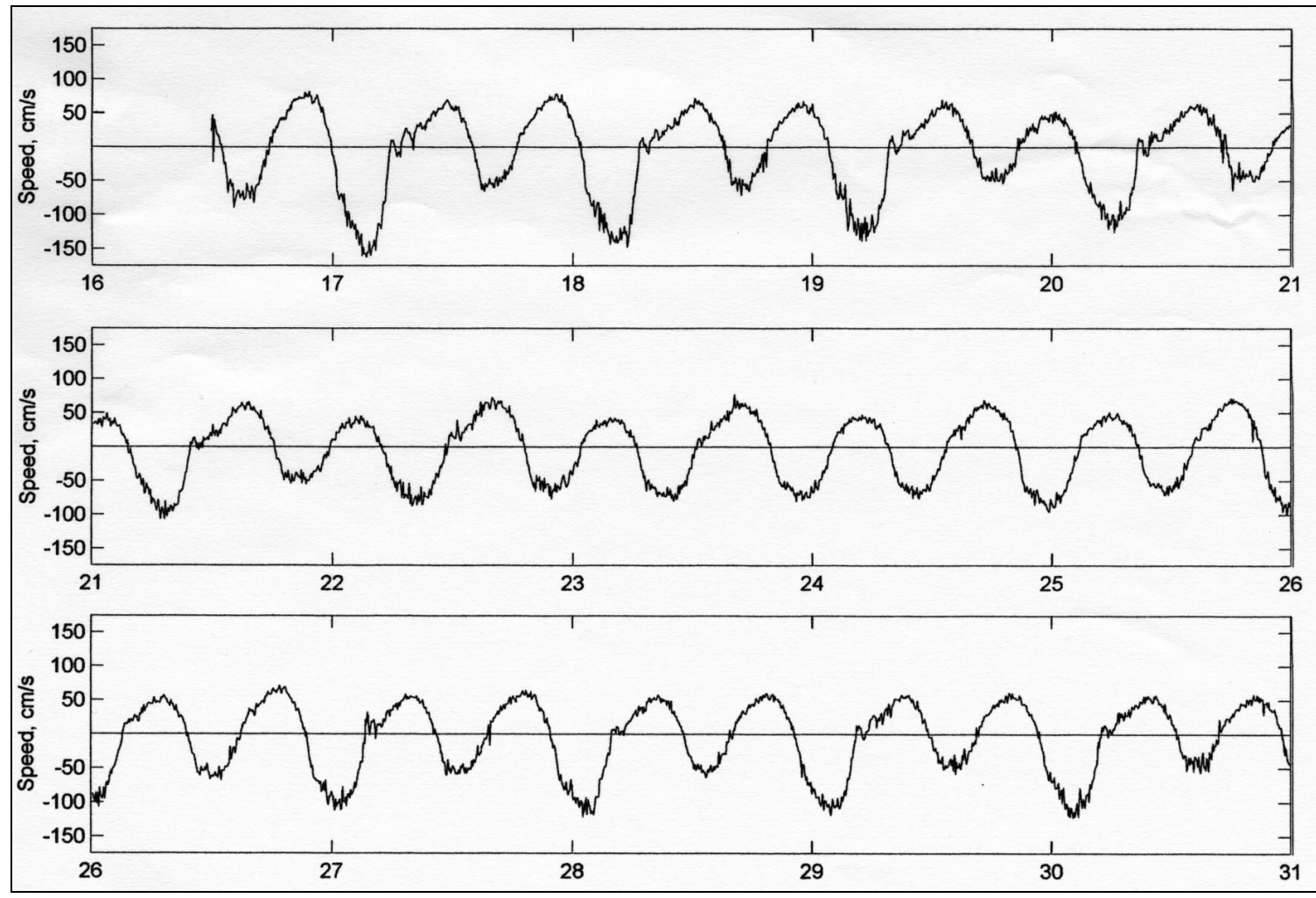

Figure 64. Ebb (-) and flood (+) near-surface currents for May 16 - 31, 1999

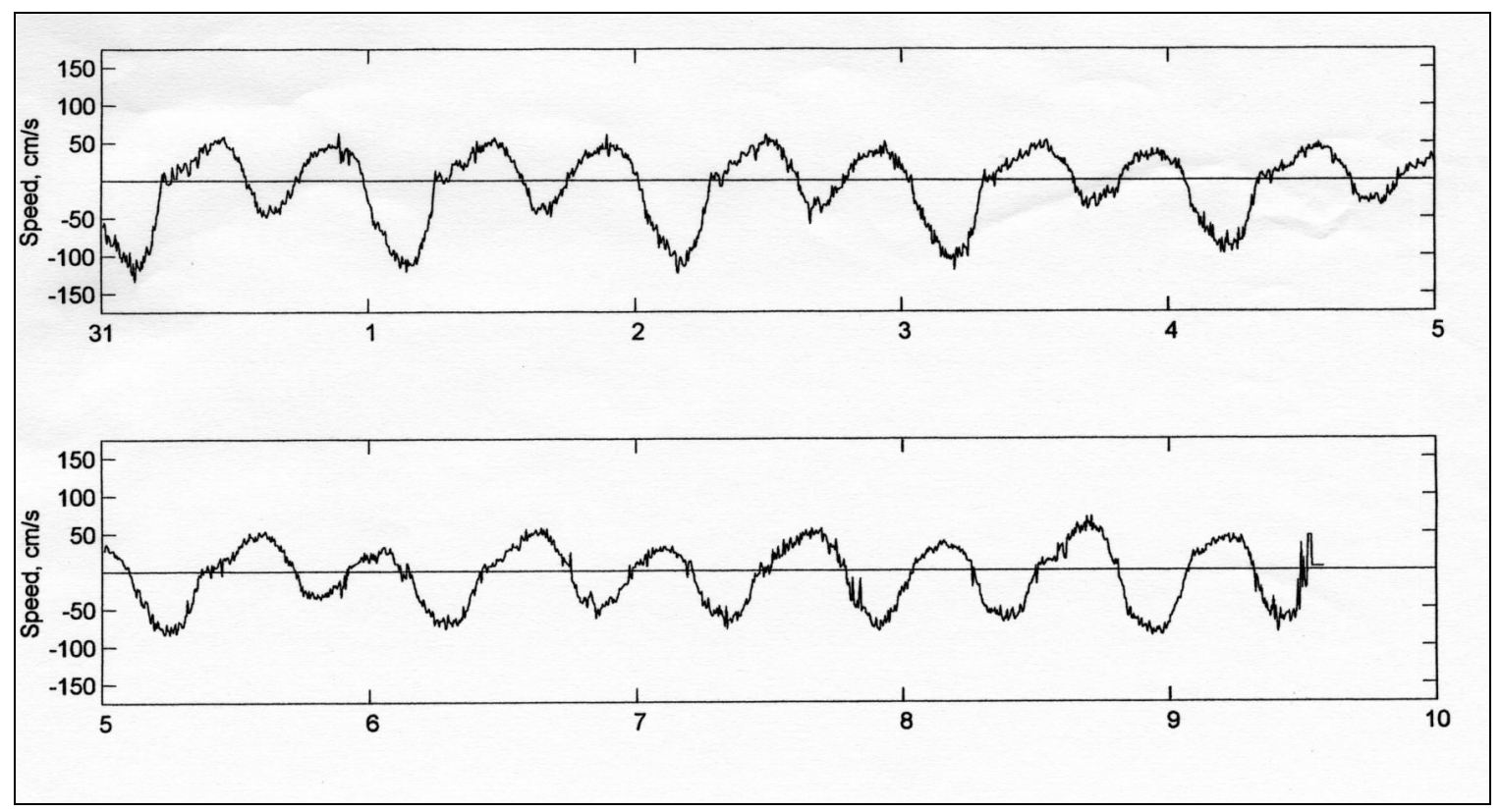

Figure 65. Ebb (-) and flood (+) near-surface currents for June 1 - 9, 1999 


\section{REPORT DOCUMENTATION PAGE}

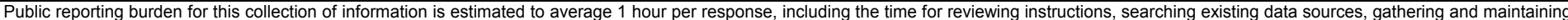

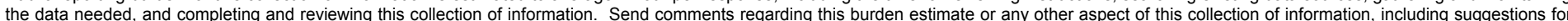

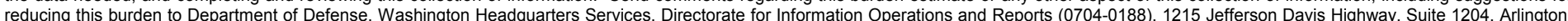

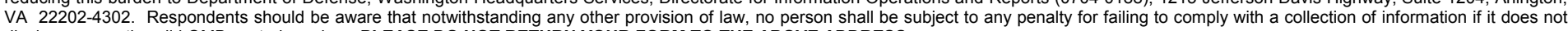
display a currently valid OMB control number. PLEASE DO NOT RETURN YOUR FORM TO THE ABOVE ADDRESS.
1. REPORT DATE (DD-MM-YYYY)
September 2001
Final report

4. TITLE AND SUBTITLE

Morro Bay Harbor, California, Wave and Current Data Summary Report

\section{DATES COVERED (From - To)}

5a. CONTRACT NUMBER

5b. GRANT NUMBER

5c. PROGRAM ELEMENT NUMBER

6. AUTHOR(S)

Andrew W. Garcia

\section{5d. PROJECT NUMBER}

5e. TASK NUMBER

5f. WORK UNIT NUMBER

8. PERFORMING ORGANIZATION REPORT NUMBER

ERDC/CHL TR-01-21

U.S. Army Engineer Research and Development Center

Coastal and Hydraulics Laboratory

3909 Halls Ferry Road

Vicksburg, MS 39180-6199

\section{SPONSORING / MONITORING AGENCY NAME(S) AND ADDRESS(ES)}

10. SPONSOR/MONITOR'S ACRONYM(S)

U.S. Army Corps of Engineers

Washington, DC 20314-1000

11. SPONSOR/MONITOR'S REPORT NUMBER(S)

\section{DISTRIBUTION / AVAILABILITY STATEMENT}

Approved for public release; distribution is unlimited.

\section{SUPPLEMENTARY NOTES}

\section{ABSTRACT}

Morro Bay Harbor, CA, was selected for inclusion in the Monitoring Completed Navigation Project Program in 1997 and monitoring was initiated in 1998. The objective was to determine if nonstructural modifications at the harbor entrance were performing as predicted by design tools. Monitoring included the collection of wave and current data, bathymetric data, and ground and photogrammetric surveys of the south breakwater. This report presents wave and current data obtained at the site during the monitoring effort. A subsequent report will provide further analysis as well as results of the comprehensive monitoring effort.

\section{SUBJECT TERMS}

Broad Band Acoustic Doppler Current Profiler

Current data

16. SECURITY CLASSIFICATION OF:

a. REPORT

UNCLASSIFIED b. ABSTRACT

UNCLASSIFIED
Morro Bay Harbor, CA

Slope array gauge system

Wave data

17. LIMITATION
OF ABSTRACT

\section{Waverider data}

18. NUMBER
OF PAGES

62 19a. NAME OF RESPONSIBLE PERSON

19b. TELEPHONE NUMBER (include area code) 